\title{
Nascent-HBr Catalyzed Removal of Orthogonal Protecting Groups in Aqueous Surfactants
}

\author{
Shilpi Gupta, Smritilekha Bera* and Dhananjoy Mondal* \\ School of Chemical Sciences, Central University of Gujarat, Gandhinagar-382030, India \\ Email:1ekha026@yahoo.com/dhananjoym@yahoo.com
}

\section{$\underline{\text { Supporting Information }}$}

\begin{tabular}{|c|c|}
\hline 1. Contents: & Page No. \\
\hline $\begin{array}{l}\text { 2. BnBr catalyzed cleavage of 5,6-O-ketals of compound } 1 \mathrm{a}-\mathrm{c} \text { in } 1.4 \mathrm{M} \text { aq. surfactants } \mathrm{CTAB} \text { and } \\
\text { DTAB }\end{array}$ & S2-S3 \\
\hline 3. $\mathrm{pH}$ and conductance study of different concentration of aq. SDS at various temperature & S3-S4 \\
\hline 4. 5,6-O-isopropylidene cleavage of $1 \mathrm{a}$ at different molar concentration of catalyst $\mathrm{BnBr}$ & S4 \\
\hline 5. Effect of electrolyte $(\mathrm{NaCl})$ on the cleavage rate of 5,6-O-ketal cleavage of 1a & S4 \\
\hline $\begin{array}{l}\text { 6. }{ }^{1} \mathrm{H} \text { NMR study for the sustained-release of nascent- } \mathrm{HBr} \text { from the catalyst } \mathrm{BnBr} \text { in } \mathrm{D}_{2} \mathrm{O} \text { solution of } \\
\text { SDS }\end{array}$ & S5 \\
\hline 7. Determination of $\mathrm{pH}$ at different concentration of $\mathrm{HBr}$ (in $\mathrm{mmol}$ ) in aq. SDS & S5 \\
\hline 8. Study on $\mathrm{pH}$ gradient of different bromide catalysts in aq. SDS as a source of nascent $-\mathrm{HBr}$ & S6 \\
\hline 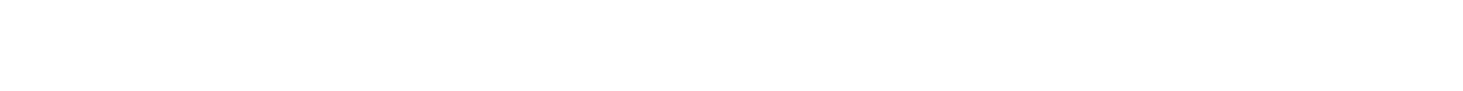 & S6-S7 \\
\hline $\begin{array}{l}\text { 10. Comparison study of cleavage reactions with different types of catalysts }(\mathrm{BnBr}, \mathrm{p}-\mathrm{MeBnBr}, \mathrm{p}- \\
\left.\mathrm{NO}_{2} \mathrm{BnBr} \text {, and }{ }^{\mathrm{t}} \mathrm{BuBr}\right)\end{array}$ & S7 \\
\hline 11. Synthesis of compound $\mathbf{1 5}$. & S8 \\
\hline 12. References & S8 \\
\hline 13. Figure $S 9$ to $S 27$ for the ${ }^{1} \mathrm{H}$ and ${ }^{13} \mathrm{C}$ NMR spectrum of compounds $\mathbf{2 a - 2} \mathbf{j}$ & S9-S27 \\
\hline 14. Figure $\mathrm{S} 28$ to $\mathrm{S} 34$ for the ${ }^{1} \mathrm{H}$ and ${ }^{13} \mathrm{C}$ NMR spectrum of compounds $4 \mathbf{a}-4 \mathbf{d}$ & S28-S34 \\
\hline 15. Figure $\mathrm{S} 35$ to $\mathrm{S} 49$ for the ${ }^{1} \mathrm{H}$ and ${ }^{13} \mathrm{C}$ NMR spectrum of compounds $\mathbf{5 b}-\mathbf{1 3} \mathbf{b}$ & S35-S49 \\
\hline 16. Figure $\mathrm{S} 50$ to $\mathrm{S} 53$ for the ${ }^{1} \mathrm{H}$ and ${ }^{13} \mathrm{C}$ NMR spectrum of compounds $\mathbf{1 6 a}$ and $\mathbf{1 6} \mathbf{b}$ & S50-S53 \\
\hline 17. Figure S54 for the ${ }^{1} \mathrm{H}$ NMR spectrum of pure SDS & S54 \\
\hline 18. Figure $\mathrm{S} 55$ to $\mathrm{S} 74$ for the ${ }^{1} \mathrm{H}$ and ${ }^{13} \mathrm{C}$ NMR spectrum of compounds $\mathbf{1 a}-\mathbf{1 j}$ & S55-S74 \\
\hline 19. Figure $\mathrm{S} 75$ to $\mathrm{S} 82$ for the ${ }^{1} \mathrm{H}$ and ${ }^{13} \mathrm{C}$ NMR spectrum of compounds $\mathbf{3 a - 3 d}$ & S75-S82 \\
\hline 20. Figure $\mathrm{S} 83$ to $\mathrm{S} 97$ for the ${ }^{1} \mathrm{H}$ and ${ }^{13} \mathrm{C}$ NMR spectrum of compounds $\mathbf{5 a - 1 4 a}$ & S83-S97 \\
\hline 21. Figure $\mathrm{S} 98$ to $\mathrm{S} 101$ for the ${ }^{1} \mathrm{H}$ and ${ }^{13} \mathrm{C}$ NMR spectrum of compounds $\mathbf{1 5}$ and $\mathbf{1 8}$ & S98-S101 \\
\hline
\end{tabular}


$\mathrm{BnBr}$ catalyzed cleavage of 5,6-O-ketals of compound 1a-c in $1.4 \mathrm{M}$ aq. surfactant $\mathrm{CTAB}$ and DTAB:

The benzyl bromide $(0.15 \mathrm{mmol})$ was added to a separate solution of $\mathbf{1 a}, \mathbf{1 b}$ and $\mathbf{1 c}(2.0 \mathrm{mmol})$ in $0.14 \mathrm{M}$ aq. surfactants $(10 \mathrm{~mL})$ with vigorous stirring at room temperature. Each reaction was monitored by TLC. After completion, the reaction mixture was destabilised with ethyl acetate, and the two layers were separated. The organic layer was dried over $\mathrm{Na}_{2} \mathrm{SO}_{4}$, concentrated and purified through silica gel to furnish $\mathbf{2 a - 2 c}$ respectively.<smiles>CC1(C)CC(C2OC3OC(C)(C)OC3[C@H]2[18OH])CO1</smiles><smiles>CO[C@H]1C(COC(C)(C)C)OC2OC(C)(C)O[C@H]21</smiles>

aq. surfactants (DTAB, CTAB)

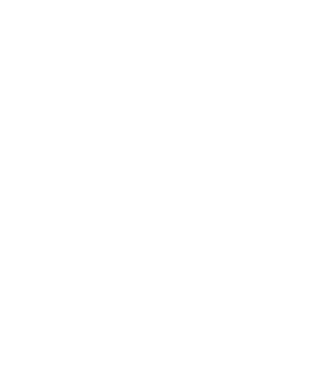<smiles>OC1C2OC3(CCCCC3)OC2OC(C2COC3(CCCCC3)O2)[C@@H]1O</smiles><smiles>OC[C@H](O)C1OC2OC3(CCCCC3)OC2[C@H]1O</smiles>

\begin{tabular}{|c|c|c|c|c|c|c|c|c|}
\hline \multicolumn{2}{|l|}{ Time } & $3 \mathrm{~h}$ & $4 \mathrm{~h}$ & $5 \mathrm{~h}$ & $6 \mathrm{~h}$ & $8 \mathrm{~h}$ & $10 \mathrm{~h}$ & $16 \mathrm{~h}$ \\
\hline Surfactant & Conc. (M) & \multirow{2}{*}{\multicolumn{7}{|c|}{ Yield (\%) of 2a }} \\
\hline \multirow{6}{*}{ CTAB } & & & & & & & & \\
\hline & 0.06 & nd & nd & 15 & 20 & 35 & 40 & 55 \\
\hline & 0.10 & nd & nd & 10 & 15 & 20 & 30 & 50 \\
\hline & 0.14 & nd & nd & $<5$ & 10 & 15 & 25 & 50 \\
\hline & 0.18 & nd & nd & nd & $<5$ & 10 & 10 & 35 \\
\hline & 0.22 & nd & nd & nd & $<5$ & 5 & $<10$ & 30 \\
\hline \multirow[t]{5}{*}{ DTAB } & 0.06 & 5 & 10 & 25 & 30 & 45 & 55 & 75 \\
\hline & 0.10 & 5 & 5 & 15 & 20 & 35 & 45 & 70 \\
\hline & 0.14 & $<5$ & $<5$ & $<10$ & $<10$ & 20 & 25 & 65 \\
\hline & 0.18 & nd & nd & $<5$ & $<10$ & 15 & 20 & 45 \\
\hline & 0.22 & nd & nd & $<5$ & $<10$ & 10 & 30 & 35 \\
\hline \multirow[t]{7}{*}{ CTAB } & Conc. & \multicolumn{7}{|c|}{ Yield (\%) of $\mathbf{2 b}$} \\
\hline & & & & & & & & \\
\hline & 0.06 & $<5$ & 5 & 20 & 40 & 50 & 55 & 60 \\
\hline & 0.10 & $<5$ & 5 & 15 & 35 & 45 & 50 & 55 \\
\hline & 0.14 & nd & nd & $<10$ & 30 & 45 & 50 & 55 \\
\hline & 0.18 & nd & nd & 5 & 10 & 20 & 35 & 40 \\
\hline & 0.22 & nd & $\mathrm{nd}$ & nd & 5 & 15 & 20 & 35 \\
\hline \multirow[t]{2}{*}{ DTAB } & Conc. & & & & & & & \\
\hline & 0.06 & $<5$ & 15 & 25 & 40 & 55 & 60 & 65 \\
\hline
\end{tabular}




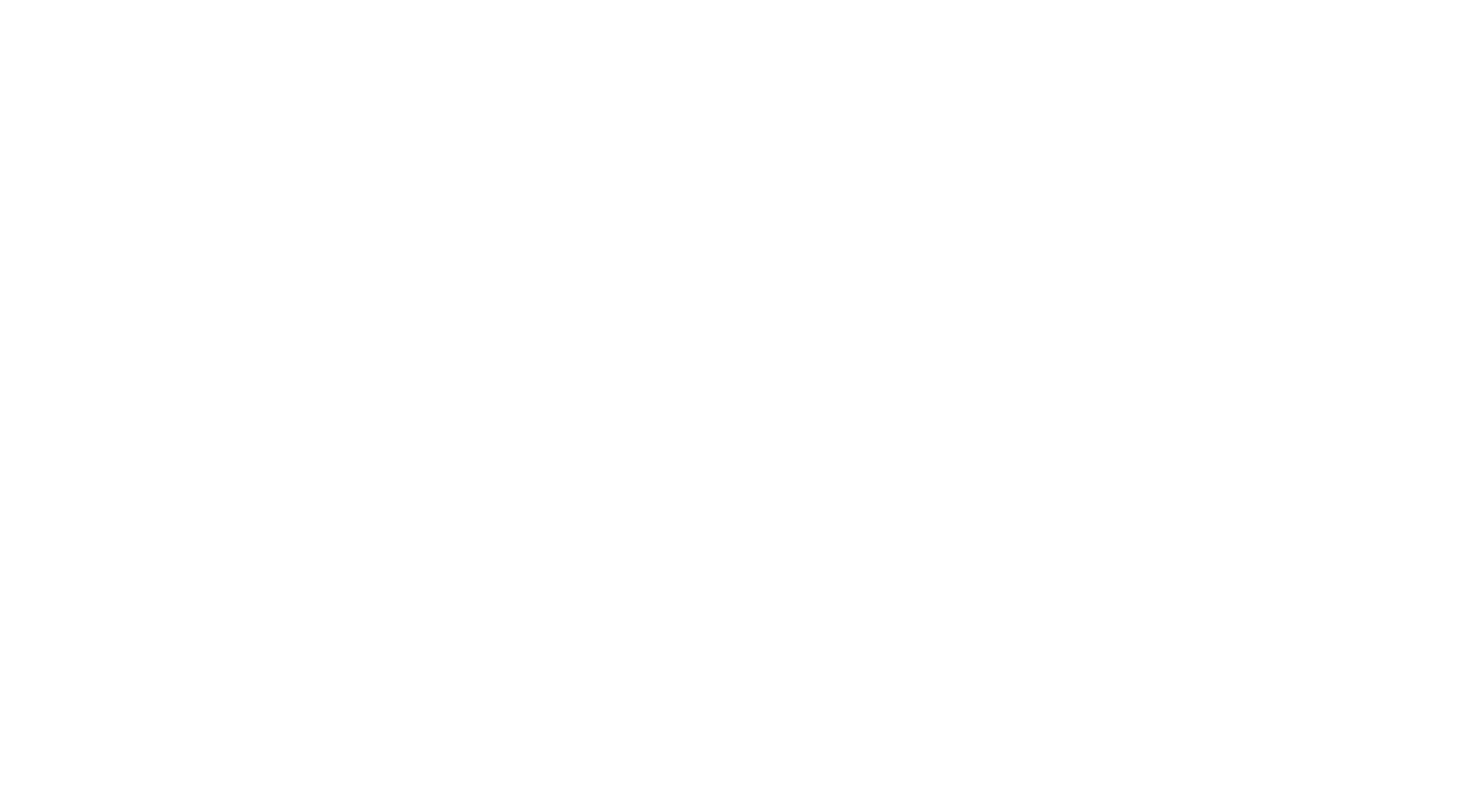

Figure S1: Comparison study of cleavage of 5,6-O-ketals of 1a-1c in different surfactants (SDS, CTAB and DTAB)

\section{The $\mathrm{pH}$ and conductance study of the different concentrations of aq. SDS at various}

\section{temperatures:}

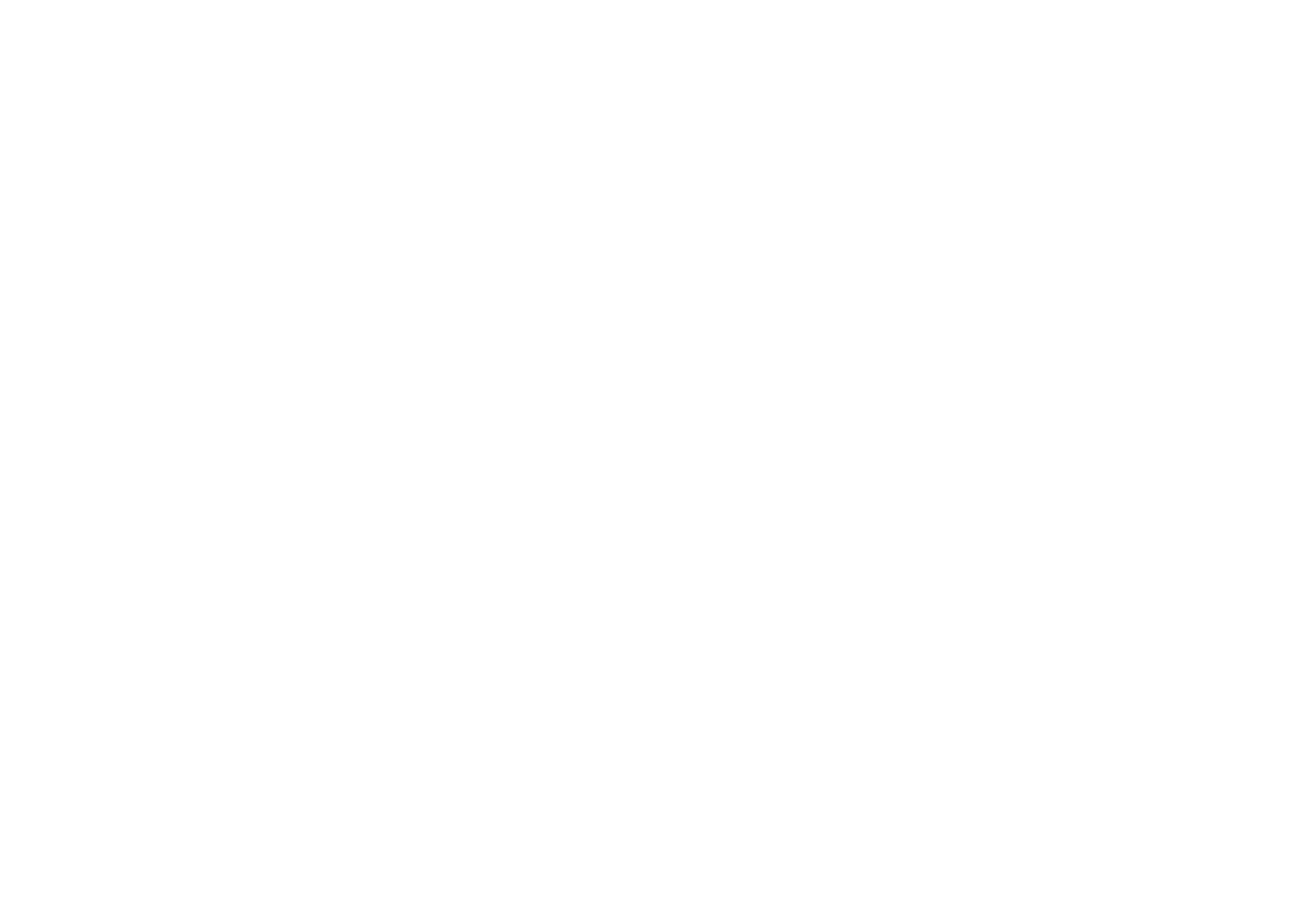

Figure S2. The $\mathrm{pH}$ of different concentration of aq. SDS at various temperatures $\left(25,40,50,60,70\right.$ and $\left.80^{\circ} \mathrm{C}\right)$ 


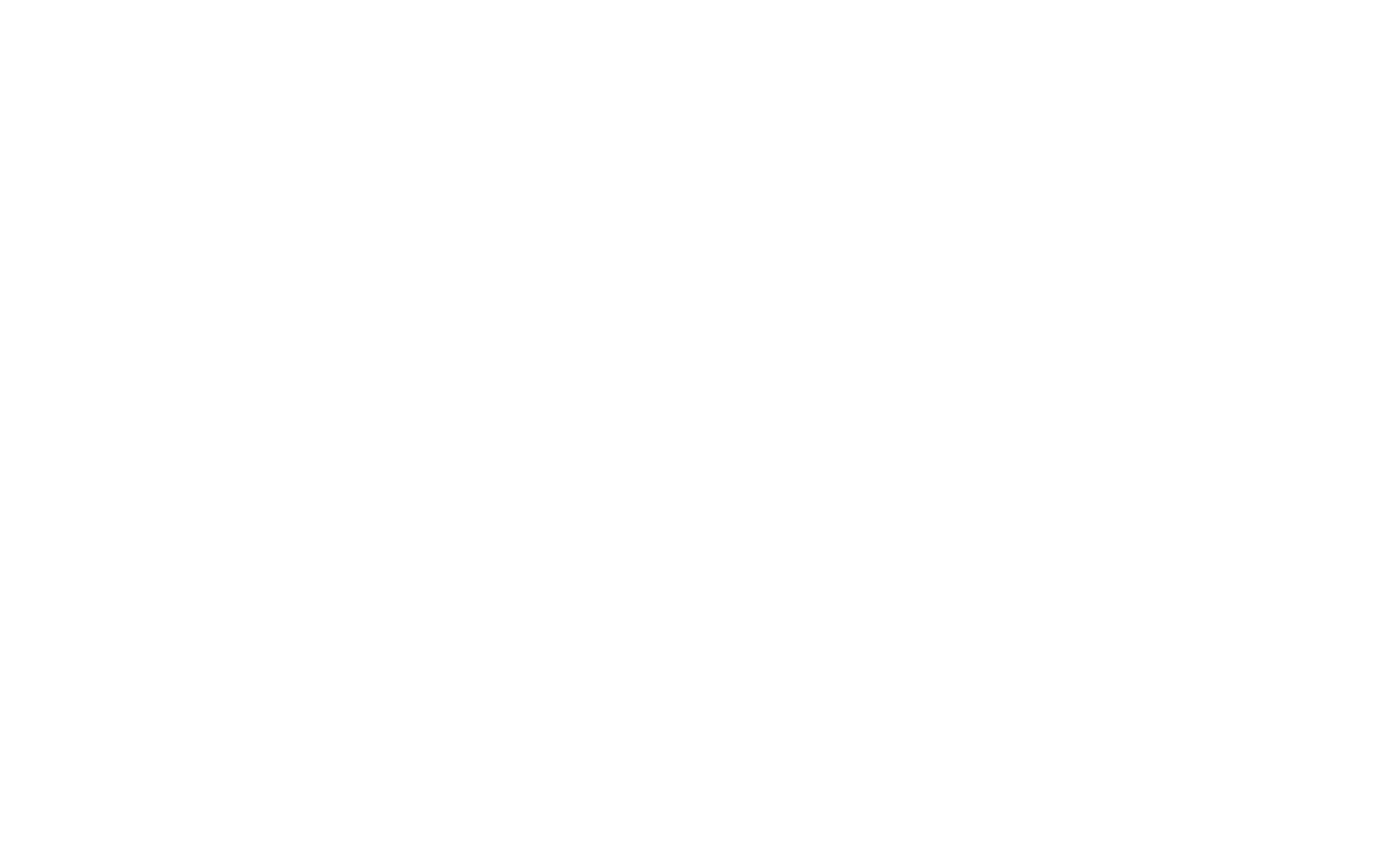

Figure S3. The specific conductance $(\kappa)$ of the SDS in aqueous medium at various temperatures $(25,40,50,60$, and $\left.70{ }^{\circ} \mathrm{C}\right)$

\section{5,6-O-isopropylidene cleavage of 1 a at different molar concentration of catalyst $\mathrm{BnBr}$}

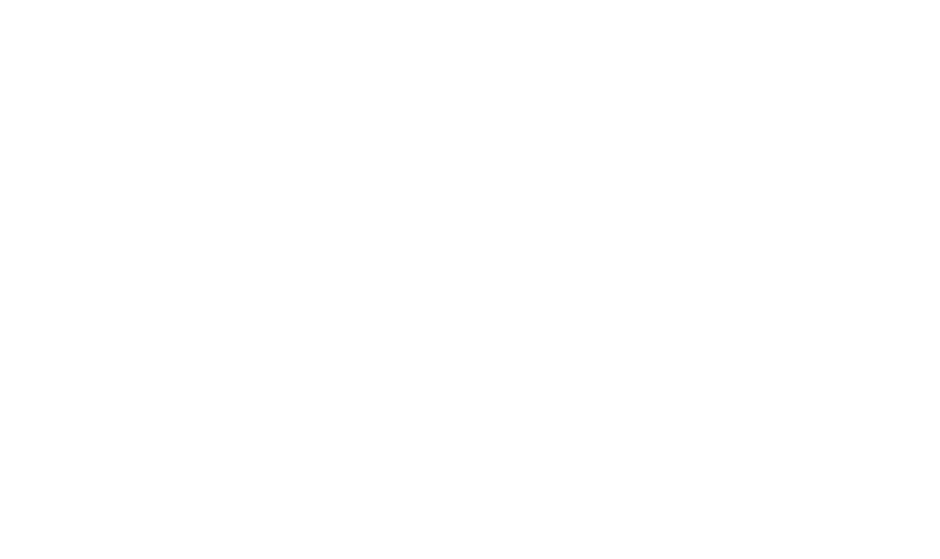

Figure S4. 5,6- $O$-isopropylidene cleavage of $1 \mathrm{a}(2.0 \mathrm{mmol})$ in $0.14 \mathrm{M}$ aq. SDS $(10 \mathrm{~mL})$ with different molar concentration of catalyst $\mathrm{BnBr}(0.05,0.15,0.25,0.35$, and $0.45 \mathrm{mmol})$ at room temperature

\section{Effect of electrolyte $(\mathrm{NaCl})$ on the cleavage rate of 5,6-O-ketal cleavage of 1a:}

To a solution of compound $1 \mathrm{a}(1.0 \mathrm{mmol})$ in $10 \mathrm{ml}$ of aq. SDS, catalyst $\mathrm{BnBr}(0.15 \mathrm{mmol})$ was added. Then different amounts of $\mathrm{NaCl}(0.0,0.05,0.1,0.3,0.6$ and $0.9 \mathrm{M})$ was added and stirred at $\mathrm{rt}$. The reactions were monitored by TLC and the detailed results are presented here. 


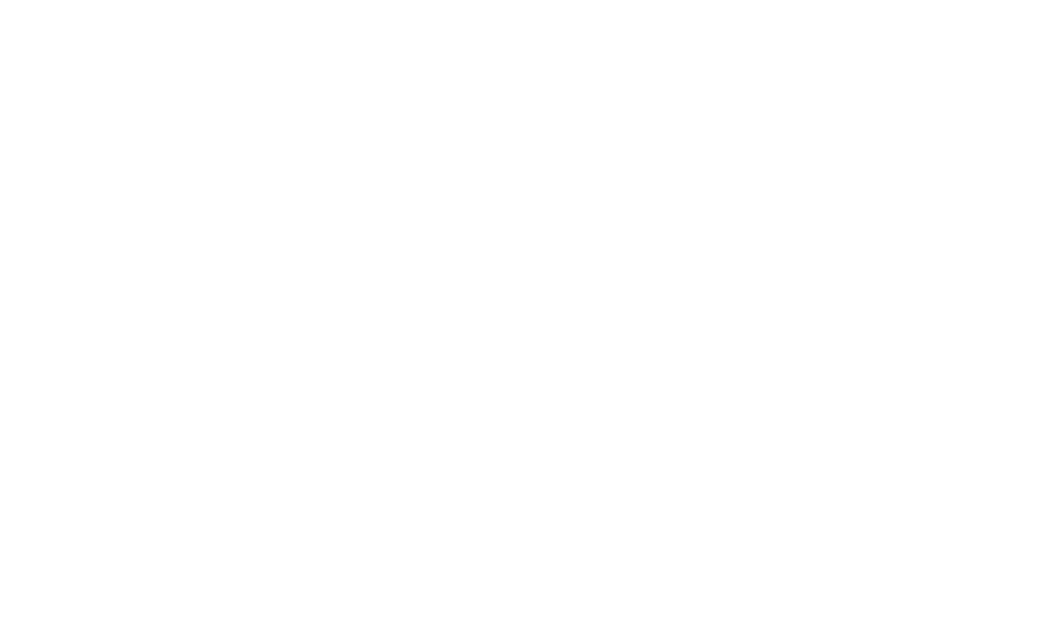

Figure S5. Effect of different concentrations of $\mathrm{NaCl}(0.0,0.05,0.1,0.3,0.6$ and $0.9 \mathrm{M})$ on the rate of 5,6-O-ketal cleavage of $\mathbf{1 a}$

${ }^{1} \mathrm{H}$ NMR study for the sustained-release of nascent- $\mathrm{HBr}$ from the catalyst $\mathrm{BnBr}$ in $\mathrm{D}_{2} \mathrm{O}$ solution of SDS:

Initially, the ${ }^{1} \mathrm{H}$ NMR spectroscopy of $1.4 \mathrm{M}$ aq. SDS in $\mathrm{D}_{2} \mathrm{O}(1.0 \mathrm{~mL})$ was determined. ${ }^{1} \mathrm{H}$ NMR $\left(500 \mathrm{MHz}, \mathrm{D}_{2} \mathrm{O}\right): \delta 3.87(\mathrm{t}, J=6.8 \mathrm{~Hz}, 2 \mathrm{H}), 1.53$ (quintet, $\left.2 \mathrm{H}\right), 1.15(\mathrm{~m}, 18 \mathrm{H}), 0.74(\mathrm{t}, J=7.0$ $\mathrm{Hz}, 3 \mathrm{H})$.

To the above NMR solution, catalyst $(\mathrm{BnBr})(0.15 \mathrm{mmol})$ was added and NMR was detected in time different interval. Initially it shows only the surfactant peaks whereas after time interval, signals related to $\mathrm{BnBr}$ and $\mathrm{BnOH}$ appeared due to the dispersion of the catalyst in $\mathrm{D}_{2} \mathrm{O}$ (discussed in manuscript, Figure 3) solution of SDS.

Determination of $\mathrm{pH}$ at different concentration of $\mathrm{HBr}$ (in mmol) in aq. SDS from $\mathrm{BnBr}$ through NMR experiment:

The $\mathrm{pH}$ of $0.14 \mathrm{M}$ aq. SDS solution $(10 \mathrm{ml})$ at different concentration (mmol) of commercially available $48 \%$ aq. $\mathrm{HBr}$ was determined at room temperature using $\mathrm{pH}$-meter (Figure 4, inset 2). The release of nascent $\mathrm{HBr}$ in mmol from the hydrolysis of $\mathrm{BnBr}$ (cat.) in $\mathrm{D}_{2} \mathrm{O}$ solution of SDS was determined from NMR experiment (Figure 4, inset 1) (eq. 1) and the $\mathrm{pH}$ of the nascent- $\mathrm{HBr}$ solution was calculated with the help of inset 2 in Figure 4.

$$
\mathrm{BnBr}+\mathrm{H}_{2} \mathrm{O} \stackrel{\text { hydrolysis }}{\longrightarrow} \mathrm{BnOH}+\mathrm{HBr}
$$




\section{Study on pH gradient of different bromide catalysts in aq. SDS as a source of nascent-HBr:}

Over a period of time, the $\mathrm{pH}$ of a freshly prepared $0.14 \mathrm{M}$ aq. SDS solution $(10 \mathrm{~mL})$ was determined and compared upon addition of different concentration of catalysts $(\mathrm{BnBr}, t-\mathrm{BuBr}, p$ $\mathrm{Me}-\mathrm{BnBr}, p$-nitro-BnBr $(0.15 \mathrm{mmol}, 0.35 \mathrm{mmol}$ and $0.80 \mathrm{mmol}$ as source of nascent- $\mathrm{HBr}$ and determined by $\mathrm{pH}$ meter ( $\mathrm{pH}$ of freshly prepared $0.14 \mathrm{M}$ aq. SDS 7.93 ).

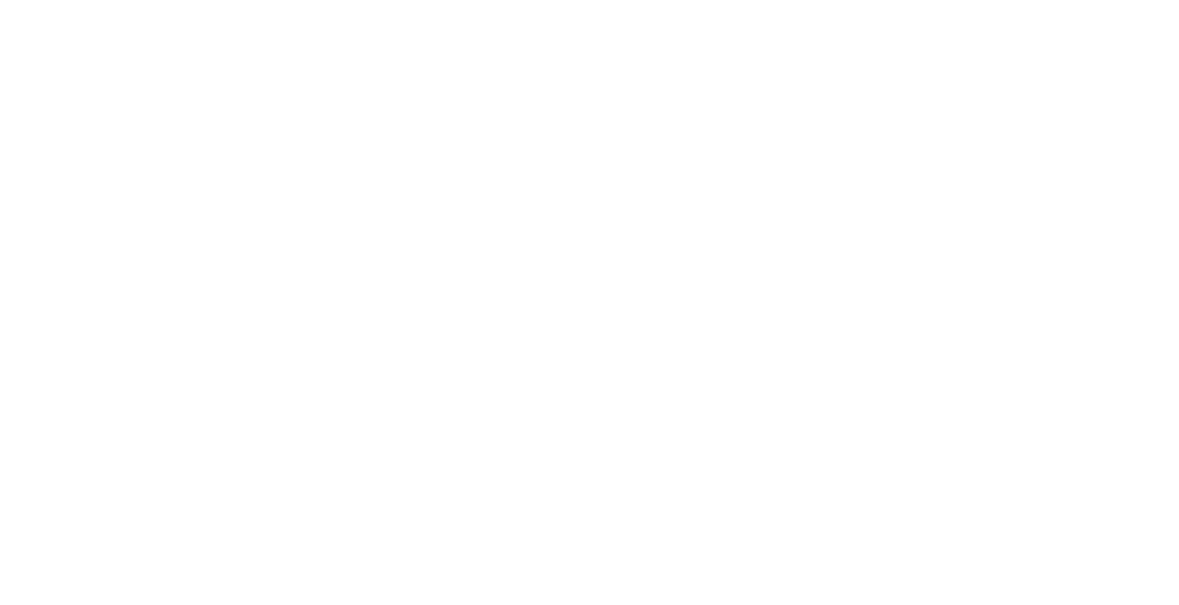

Figure S6. $\mathrm{pH}$ determination and comparison study of freshly prepared aq. SDS (0.14 M, $10 \mathrm{~mL}, \mathrm{pH} 7.93)$ upon addition of various concentration of catalyst $\mathrm{BnBr}, t-\mathrm{BuBr}, p$-Me- $\mathrm{BnBr}$ and $p$-nitro- $\mathrm{BnBr}$ at $25^{\circ} \mathrm{C}$

Determination of $\mathrm{pH}$ at different concentration of $\mathrm{HBr}$ (in $\mathrm{mmol}$ ) in aq. SDS from tertbutyl bromide ( $t$-BuBr) through NMR experiment:

Like $\mathrm{BnBr}$, an experiment was performed for the release study of $t-\mathrm{BuBr}(0.15 \mathrm{mmol})$ in $1.4 \mathrm{M}$ $\mathrm{SDS}$ in $\mathrm{D}_{2} \mathrm{O}$ and NMR was taken with time interval.

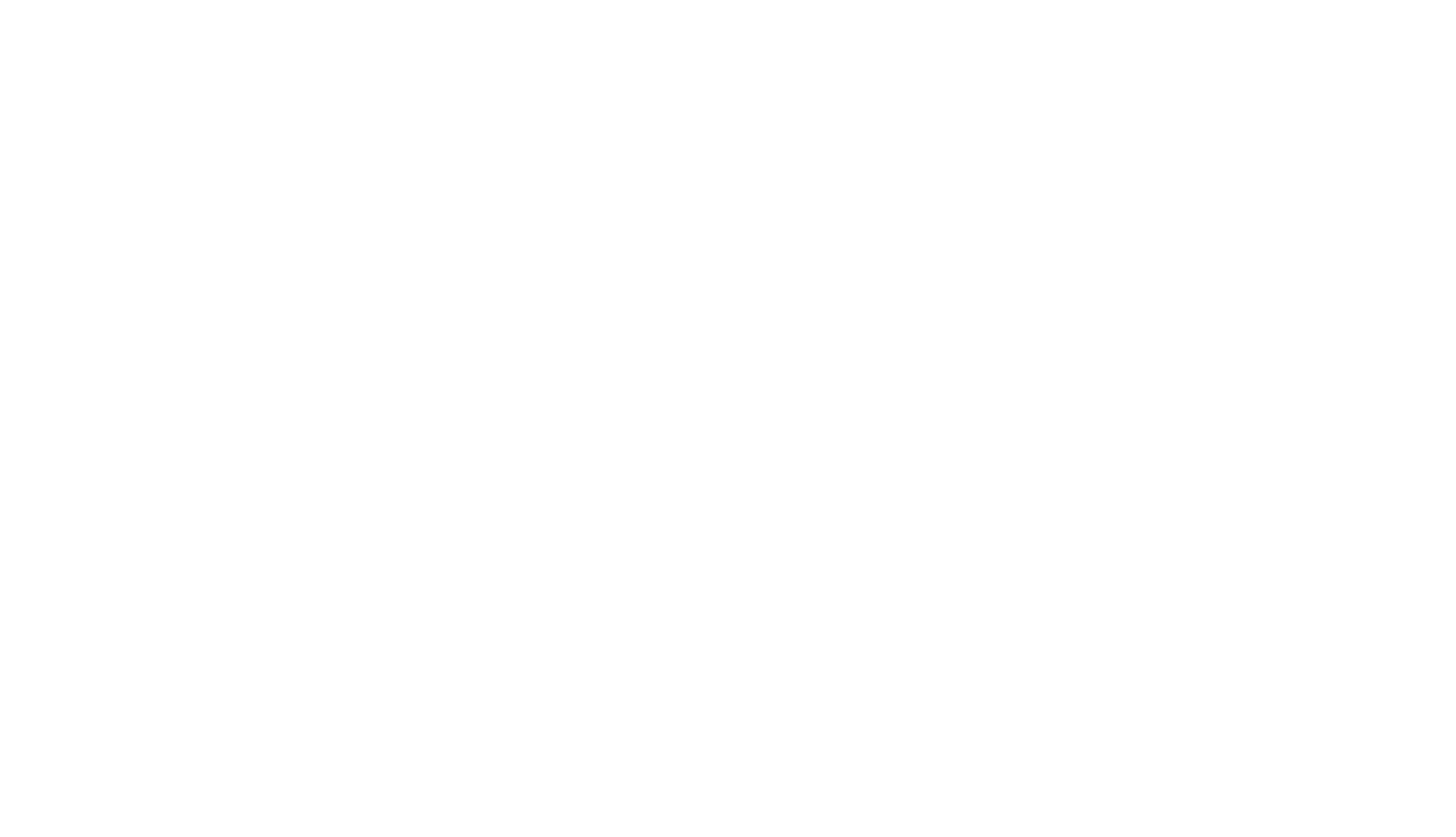

Figure S7. ${ }^{1} \mathrm{H}$ NMR of catalyst $t$ - $\mathrm{BuBr}$ in $1.4 \mathrm{M}$ SDS solution in $\mathrm{D}_{2} \mathrm{O}$ at a different time interval 


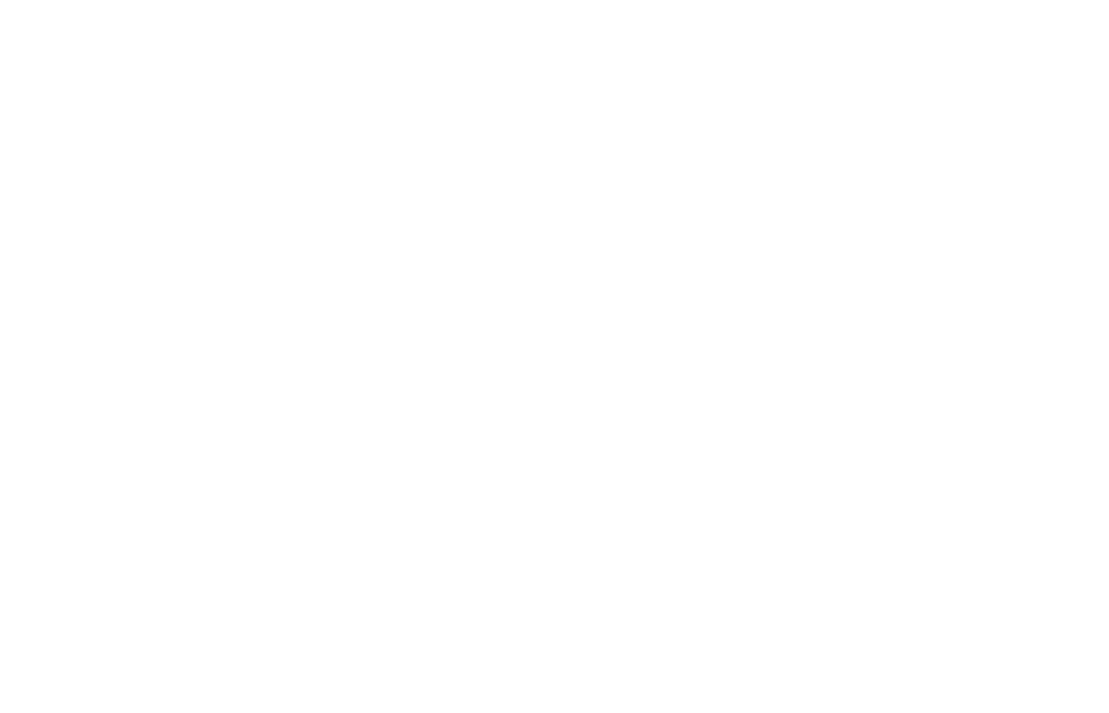

Figure S8. Rate of hydrolysis of butyl bromide $(t-\mathrm{BuBr})$ in $\mathrm{D}_{2} \mathrm{O}$ solution of SDS vs. time

Comparison study of cleavage reactions with different types of catalysts $(\mathrm{BnBr}, p-\mathrm{MeBnBr}$, $p-\mathrm{NO}_{2} \mathrm{BnBr}$, and $\boldsymbol{t}$-BuBr): The reactions were performed with the process similar to $\mathrm{BnBr}$ catalyzed cleavage of functional groups discussed above.

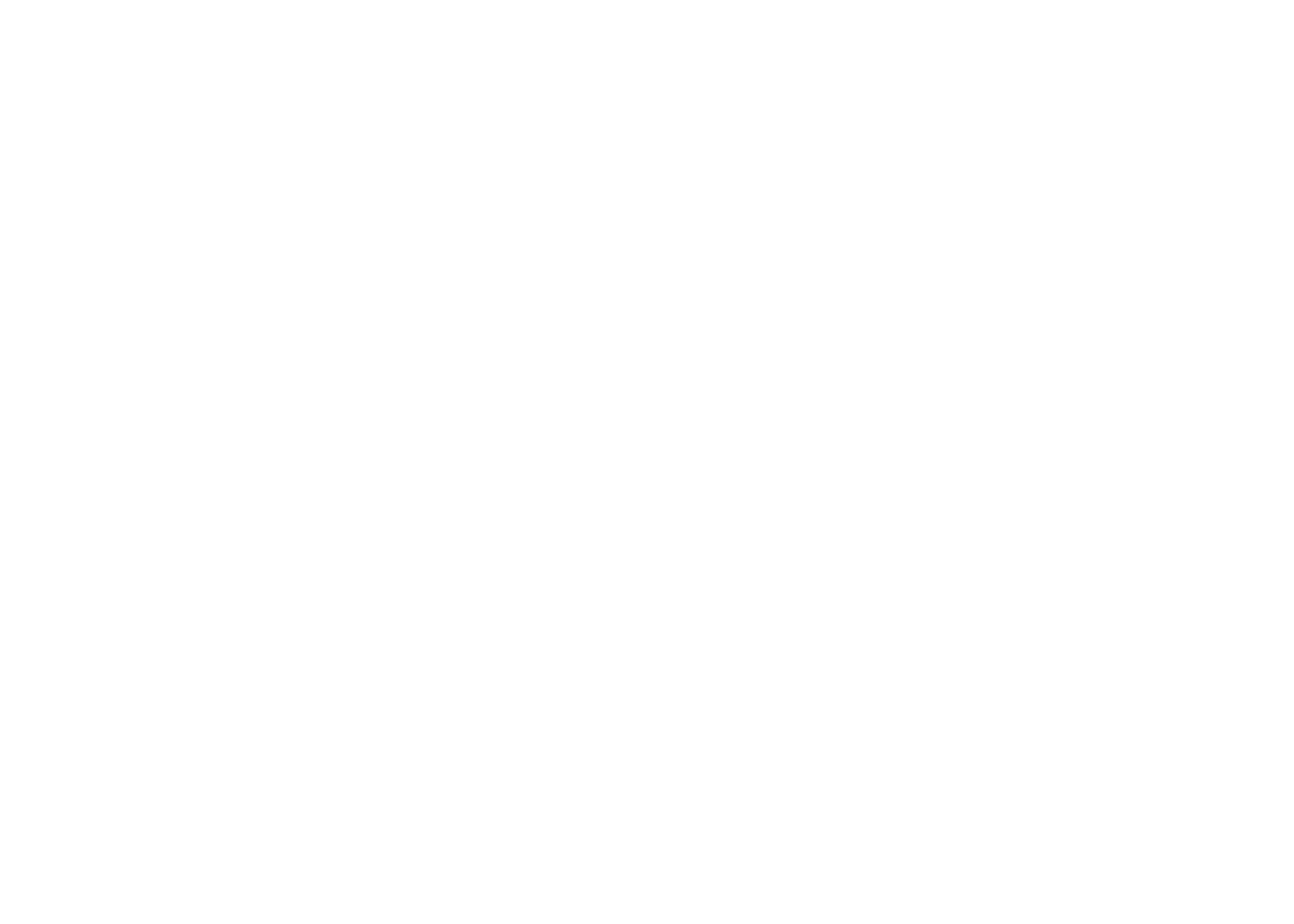




\begin{tabular}{|c|c|c|c|c|c|c|c|c|c|}
\hline \multirow[t]{3}{*}{6.} & \multirow{3}{*}{$\mathrm{TBSO}_{\mathbf{6 a}}$} & $\mathrm{BnBr}$ & 0.10 & \multirow{3}{*}{ TBSO } & 81 & & & $9 \mathrm{~h}$ & $\mathrm{rt}$ \\
\hline & & $\begin{array}{l}p- \\
\mathrm{MeBnBr}\end{array}$ & 0.10 & & 78 & & & $11 \mathrm{~h}$ & $\mathrm{rt}$ \\
\hline & & $t-\mathrm{BuBr}$ & 0.10 & & 55 & $\mathrm{HO}_{\mathrm{HOH}}^{\mathrm{OH}}$ & 35 & $5 \mathrm{~h}$ & $\mathrm{rt}$ \\
\hline 7. & MOMO $\underbrace{\stackrel{N}{=} \mathrm{CO}_{2} \mathrm{Mec}}_{14 a}$ & $\mathrm{BnBr}$ & 0.20 & 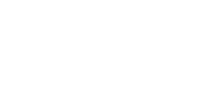 & 25 & 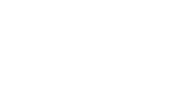 & 55 & $18 \mathrm{~h}$ & $45-50^{\circ} \mathrm{C}$ \\
\hline
\end{tabular}

\section{Synthesis of compound 15:}

The synthesis of compound $\mathbf{1 5}$ proceeds through titanium (IV) isopropoxide catalyzed nucleophilic addition of cyanide from TMSCN to the insitu generated imine of keto ulose derivative $^{\mathbf{S 1}}$ (17) on treatment with ammonium chloride and triethylamine in anhydrous methanol. ${ }^{\text {S2-4 }}$ The reaction proceeds stereoselectively to get $\mathbf{1 8}$ as single diastereomer with $90 \%$ yield, due steric hindrance imparted by the 1,2-isopropylidene functionality. The compound was characterized by NMR spectroscopy and the free amine was protected as $N$-Boc derivative upon treatment with $(\mathrm{Boc})_{2} \mathrm{O}$ and $\mathrm{Et}_{3} \mathrm{~N}$ in methanol at room temperature to get the desired compound 15.

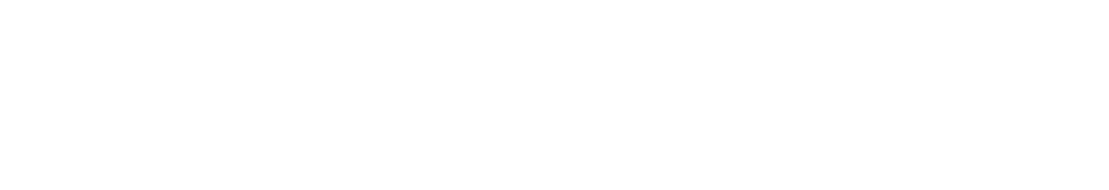

17

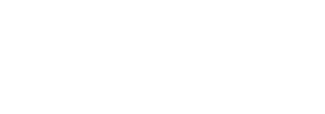

$\mathrm{MeOH}$

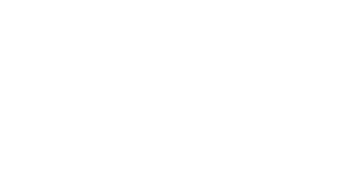

15

Scheme S1: Generation of quaternary centre at the C-3 position of keto-ulose derivative (18)

\section{References:}

S1. Y. Saito, T. A. Zevaco, L. A. Agrofoglio. Chemical synthesis of ${ }^{13} \mathrm{C}$-labeled anti-HIV nucleosides as mass-internal standards. Tetrahedron, 2002, 58, 9593.

S2. B. Miriyala, S. Bhattacharyya, J. S. Williamson. Chemoselective reductive alkylation of ammonia with carbonyl compounds: synthesis of primary and symmetrical secondary amines. Tetrahedron 2004, 60, 1463.

S3. L. Dominguez, A. N. V. Nhien, C. Tomassi, C. Len, D. Postel, J. M. Contelles, Synthesis of 4-amino-5-H-2,3-dihydroisothiazole-1,1-dioxide ring systems on sugar templates via carbanion-mediated sulfonamide intramolecular cyclization reactions (CSIC Protocols) of glyco- $\alpha$-sulfonamidonitriles. J. Org. Chem. 2004, $69,843$.

S4. D. Postel, A.N. V. Nhien, P. Villa, G. Ronco. Novel spirohydantoins of D-allose and Dribose derived from glyco- $\alpha$-aminonitriles, Tetrahedron Letters 2001, 42, 1499. 


\section{$\underline{\text { Spectrum }}$}

The ${ }^{1} \mathrm{H}$ and ${ }^{13} \mathrm{C}$ NMR spectrum of compounds (2a-2j)

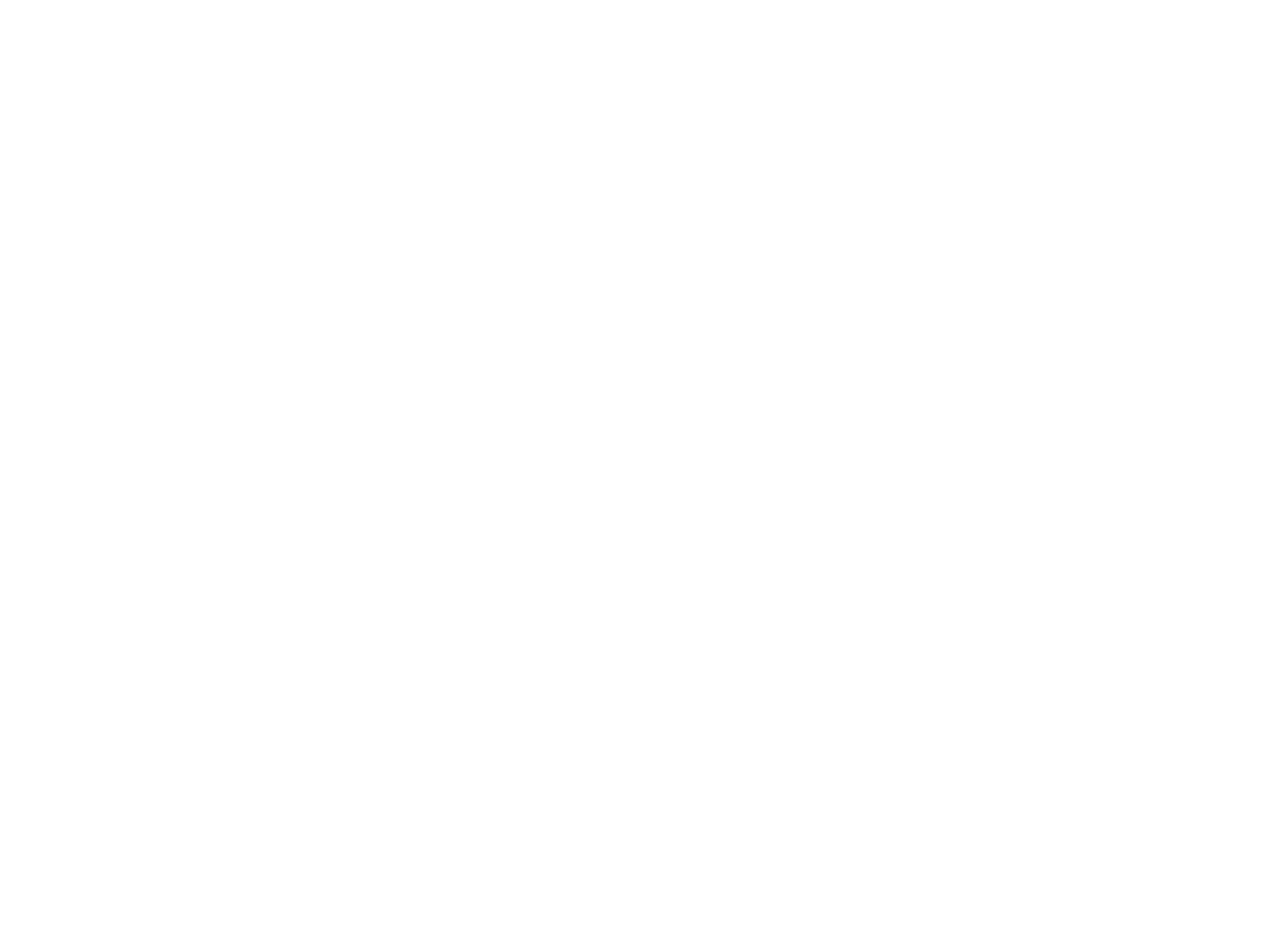

Figure S9. ${ }^{1} \mathrm{H}$ NMR of compound 2a in mixture of DMSO-d6 and $\mathrm{CDCl}_{3}$ at $500 \mathrm{MHz}$ 


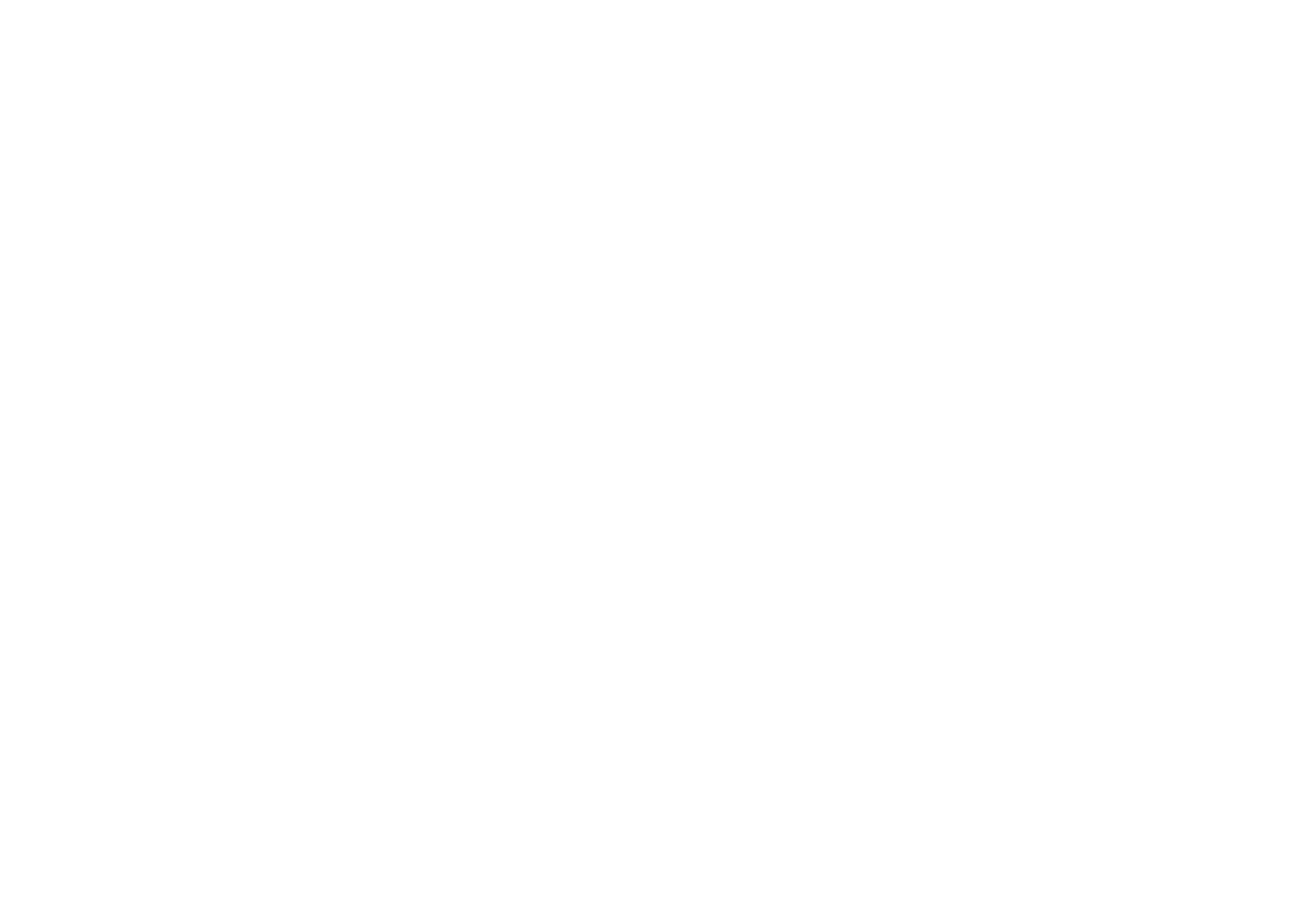

Figure S10. ${ }^{13} \mathrm{C}$ NMR of compound 2a in a mixture of DMSO-d6 and $\mathrm{CDCl}_{3}$ at $500 \mathrm{MHz}$ 


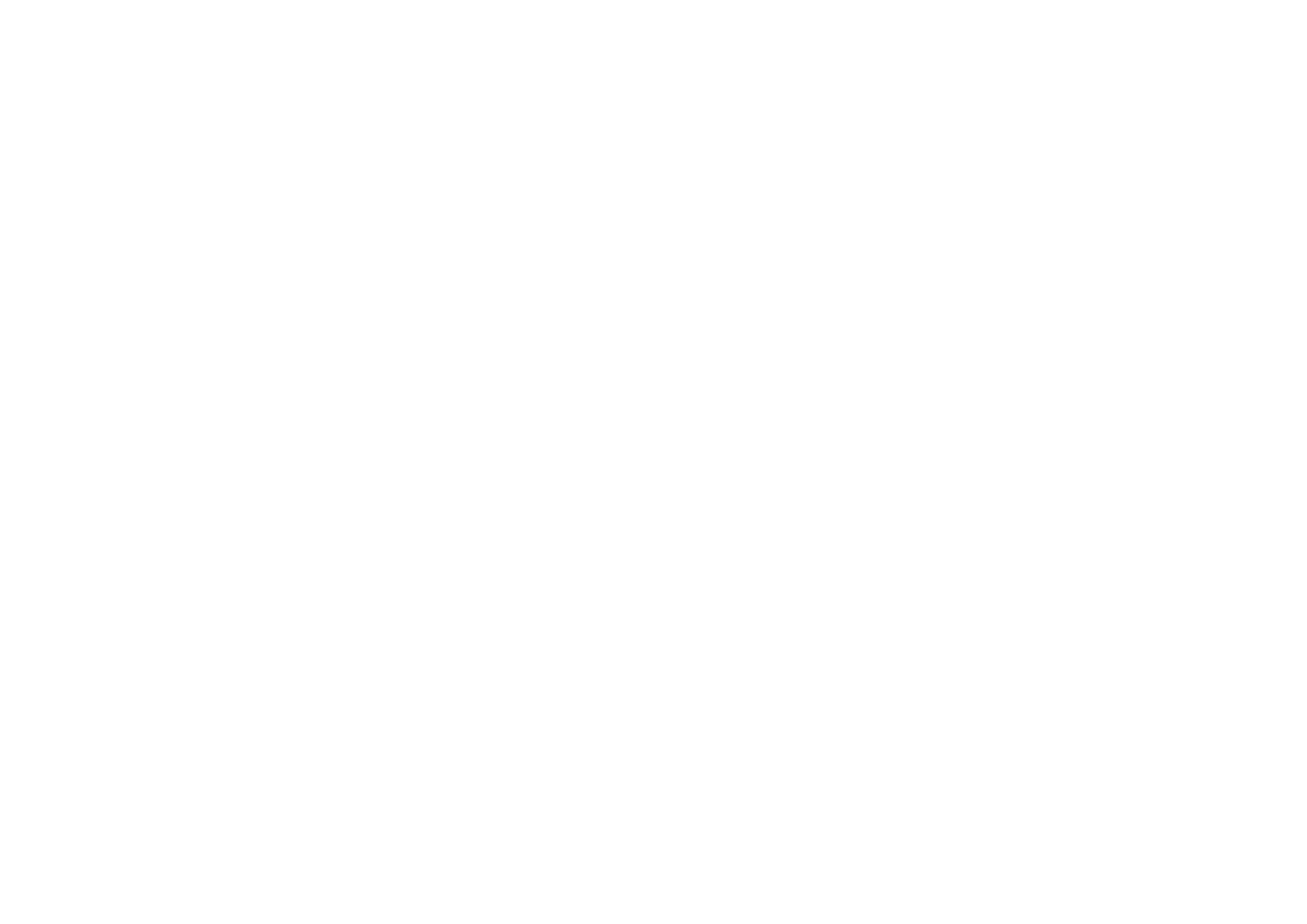

Figure S11. ${ }^{1} \mathrm{H}$ NMR of compound $\mathbf{2 b}$ in $\mathrm{CDCl}_{3}$ at $500 \mathrm{MHz}$ 


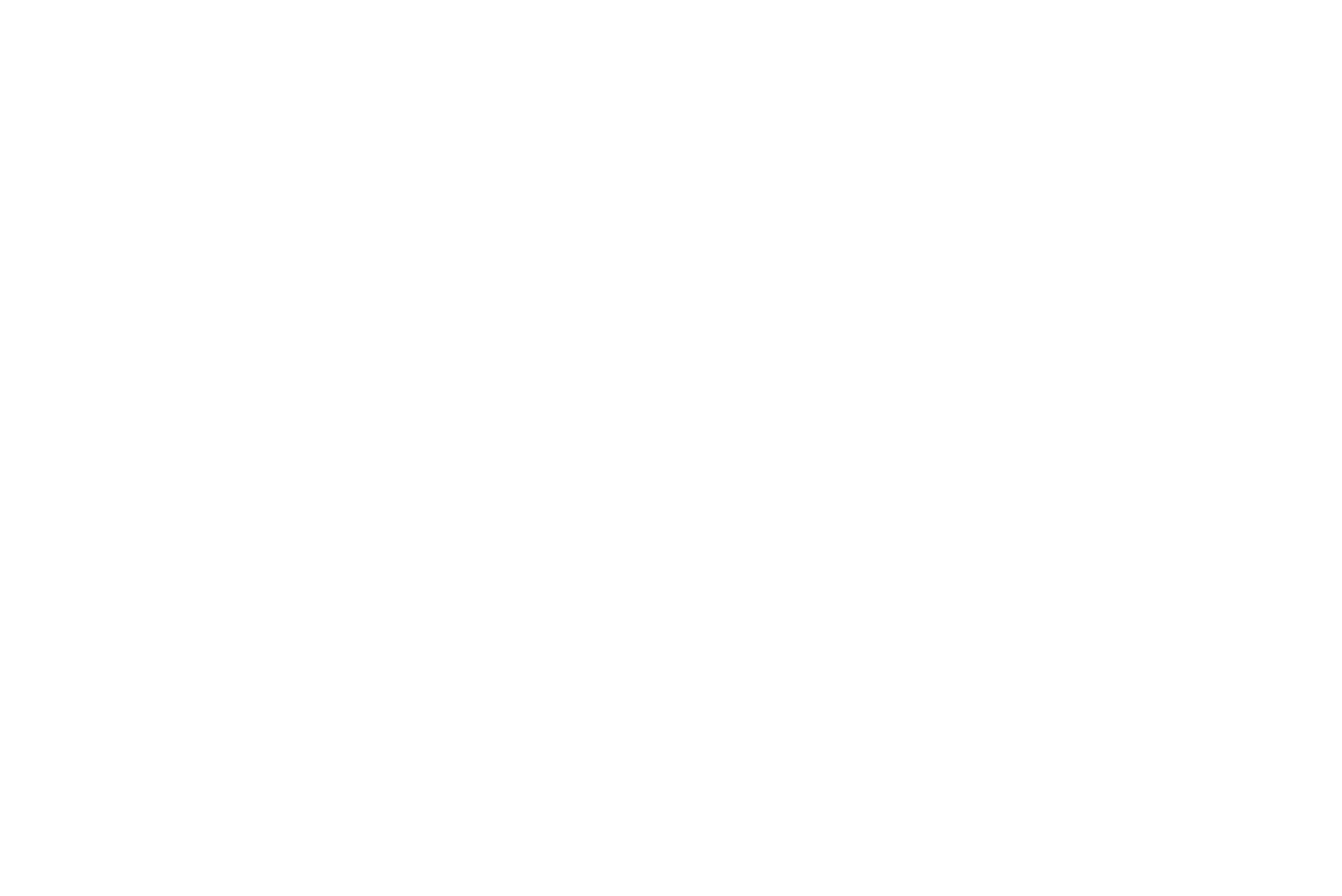

Figure S12. ${ }^{13} \mathrm{C}$ NMR of compound $\mathbf{2 b}$ in $\mathrm{CDCl}_{3}$ at $500 \mathrm{MHz}$ 


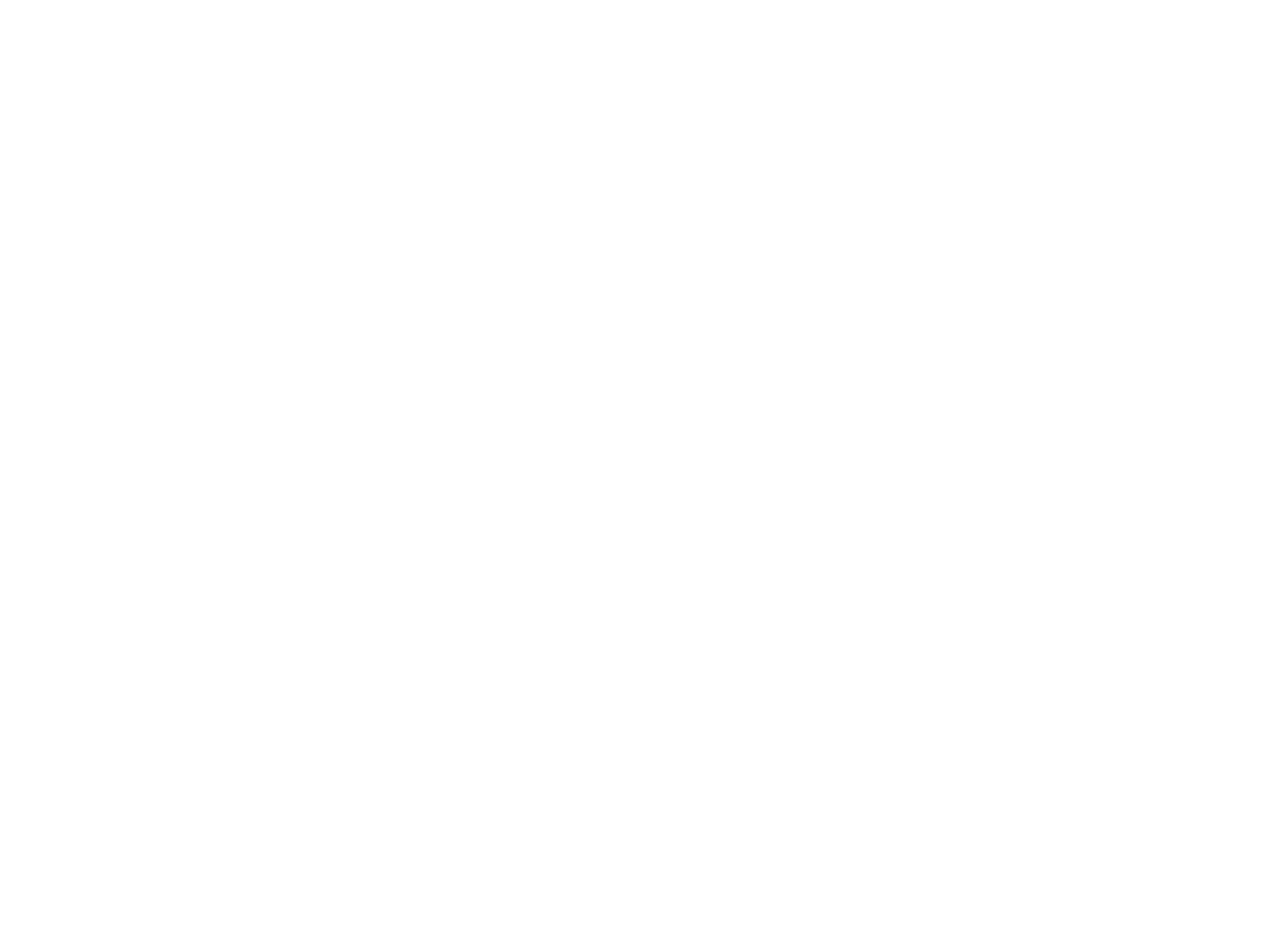

Figure S13. ${ }^{1} \mathrm{H}$ NMR of compound 2c in DMSO-d6 at $500 \mathrm{MHz}$ 


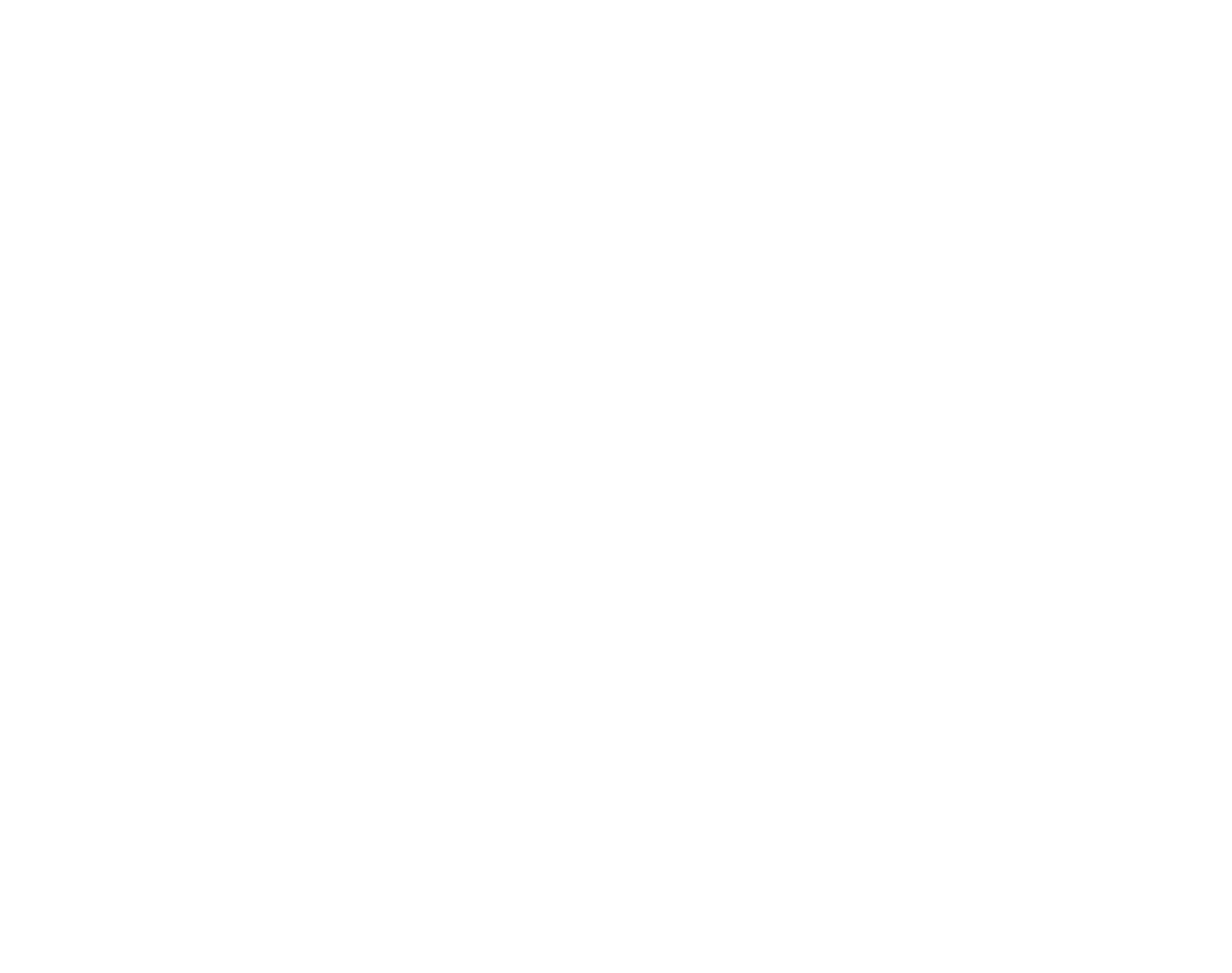

Figure S14. ${ }^{13} \mathrm{C}$ NMR of compound 2c in DMSO-d6 at $500 \mathrm{MHz}$ 


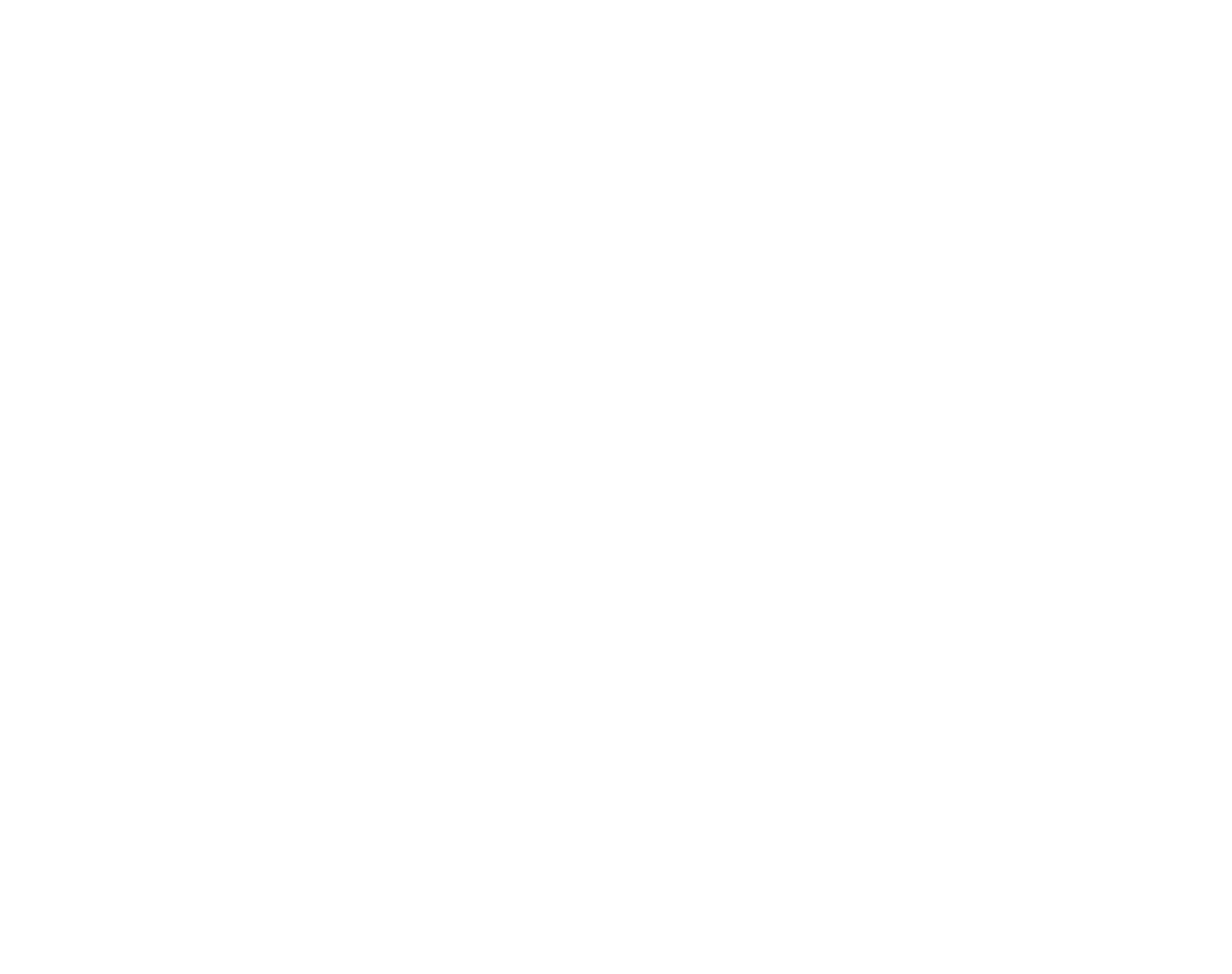

Figure S15. ${ }^{1} \mathrm{H}$ NMR of compound $\mathbf{2 d}$ in $\mathrm{CDCl}_{3}$ at $500 \mathrm{MHz}$ 


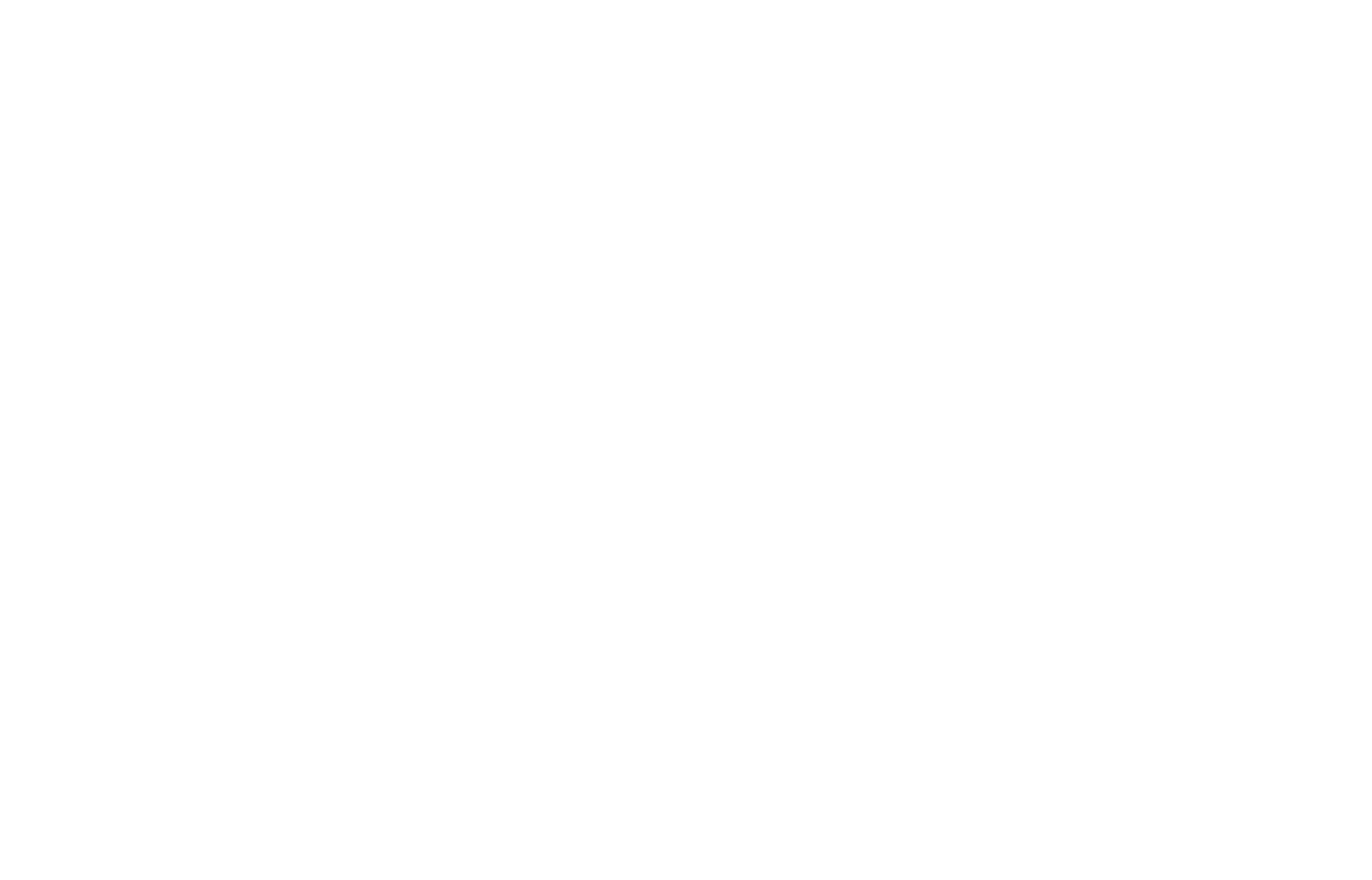

Figure S16. ${ }^{13} \mathrm{C}$ NMR of compound $2 d$ in $\mathrm{CDCl}_{3}$ at $500 \mathrm{MHz}$ 


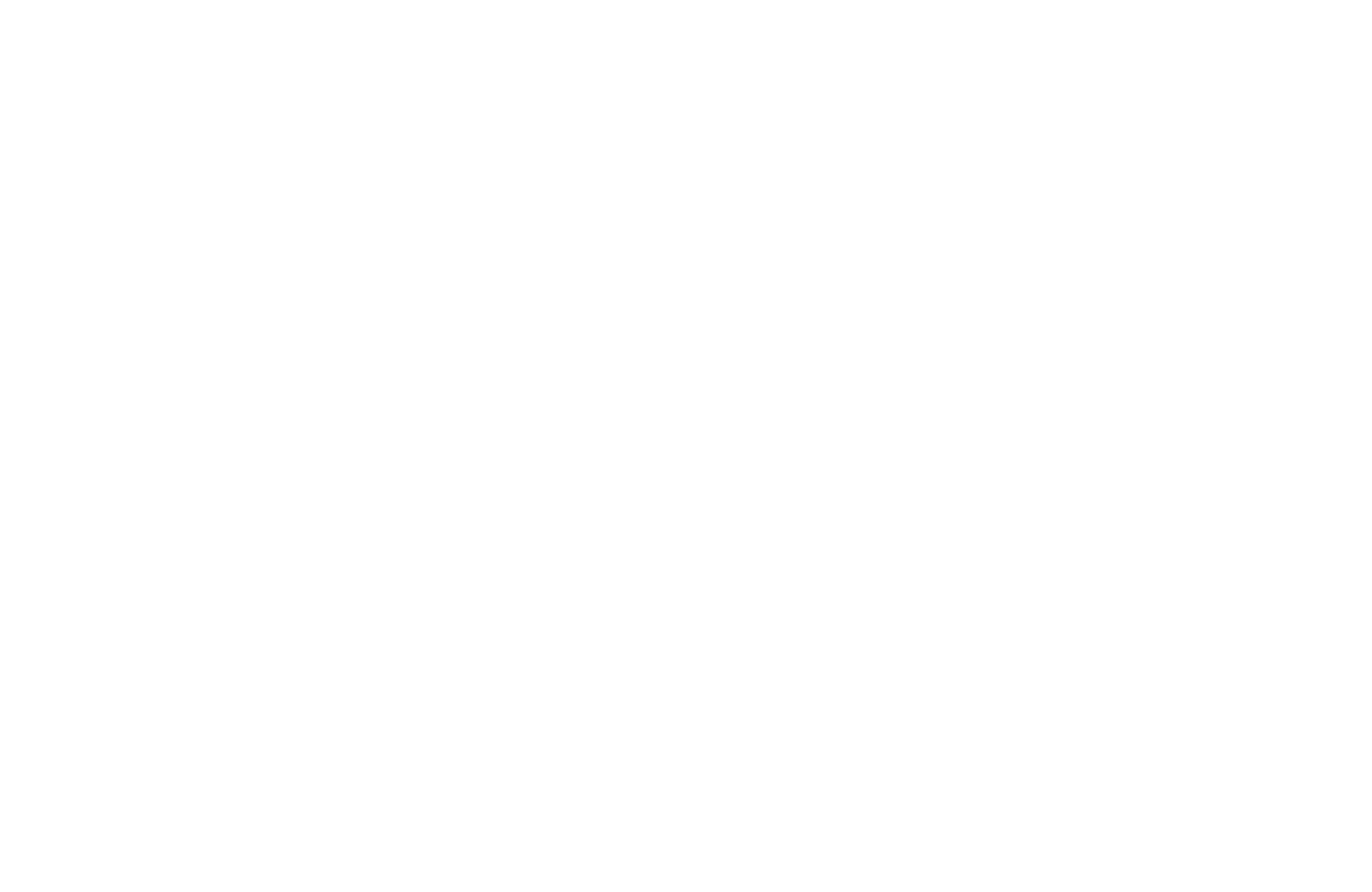

Figure S17. ${ }^{1} \mathrm{H} \mathrm{NMR}$ of compound 2e in $\mathrm{CDCl}_{3}$ at $500 \mathrm{MHz}$ 


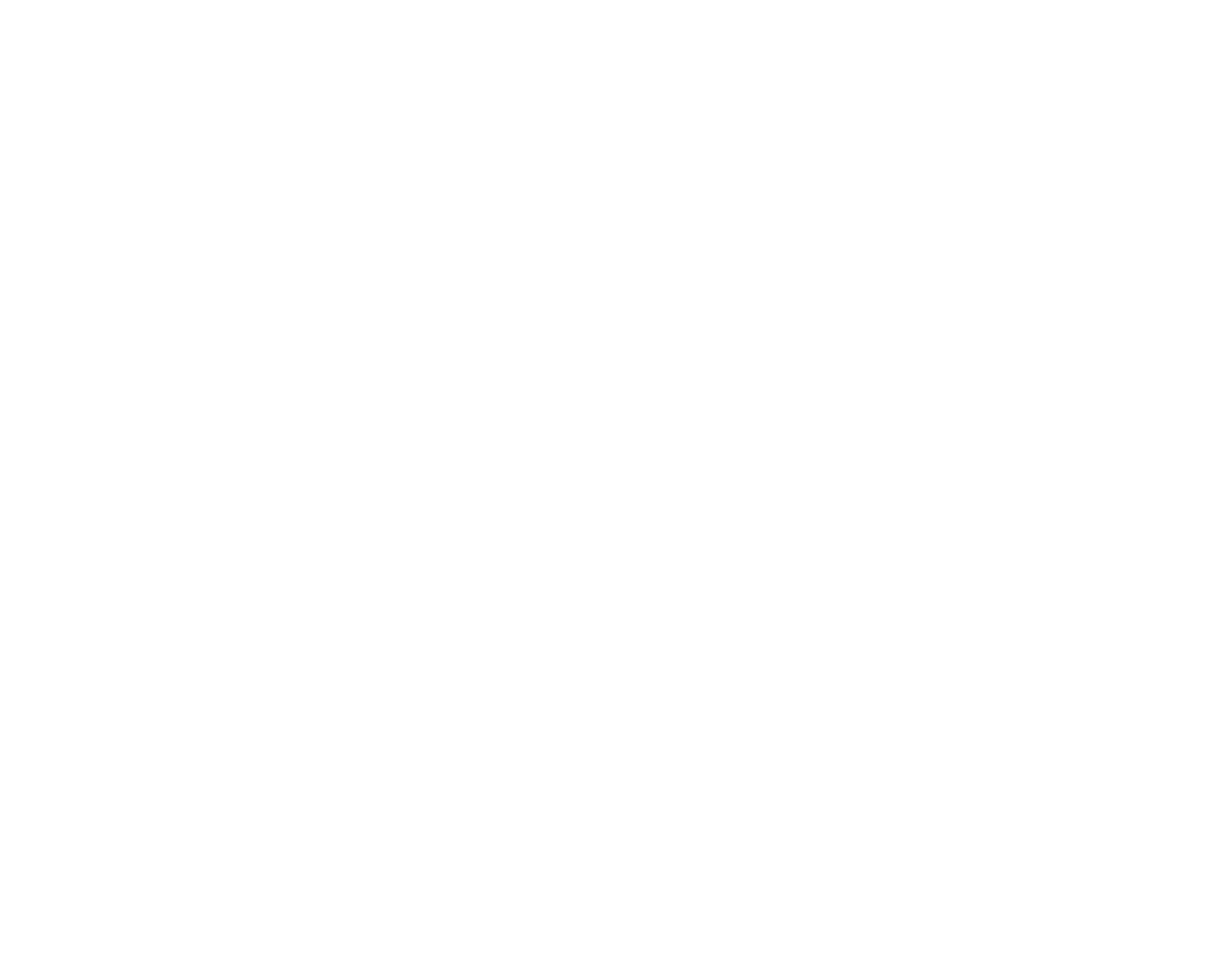

Figure S18. ${ }^{13} \mathrm{C}$ NMR of compound $2 \mathrm{e}$ in $\mathrm{CDCl}_{3}$ at $500 \mathrm{MHz}$ 


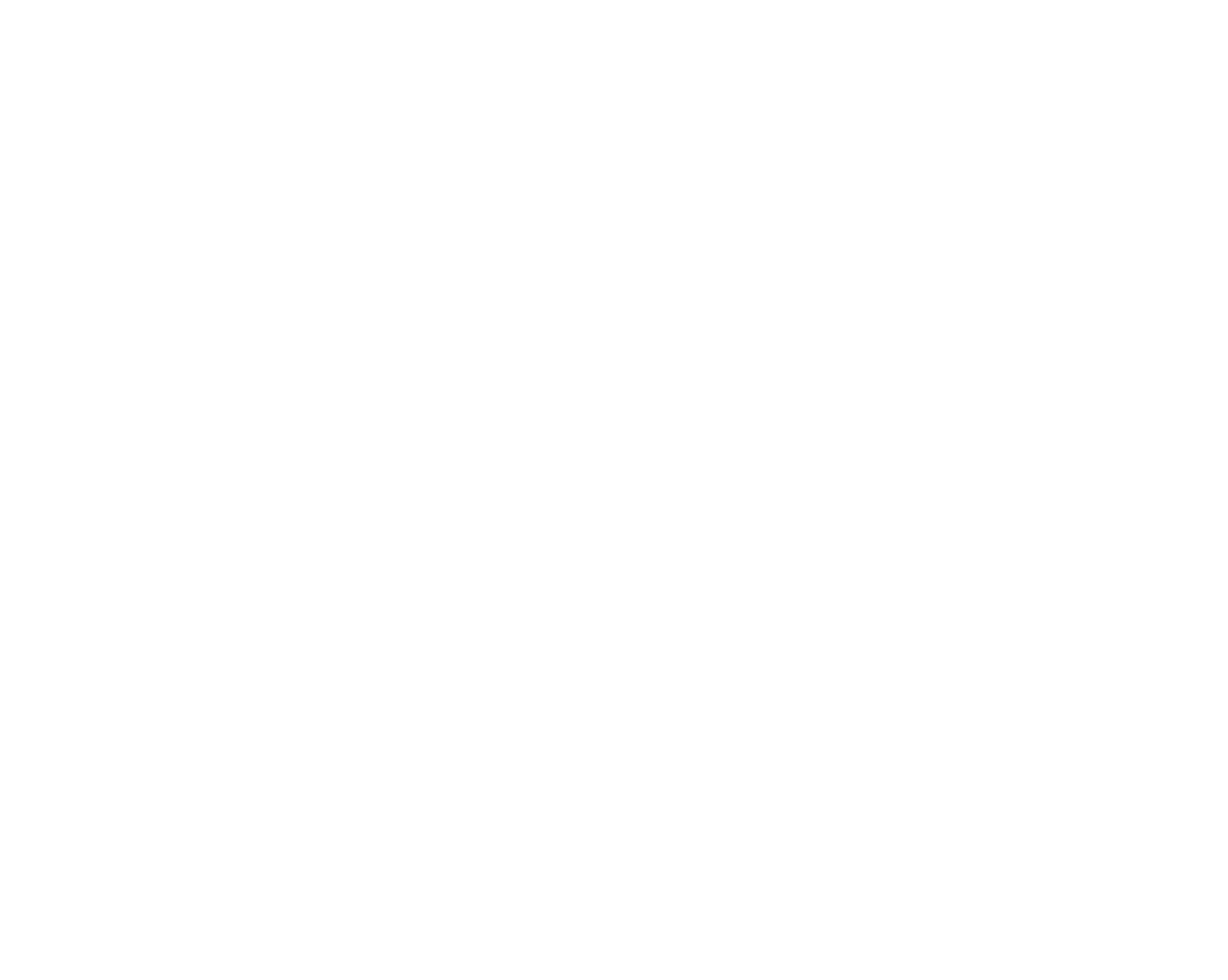

Figure S19. ${ }^{1} \mathrm{H} \mathrm{NMR}$ of compound $\mathbf{2 f}$ in $\mathrm{CDCl}_{3}$ at $500 \mathrm{MHz}$ 


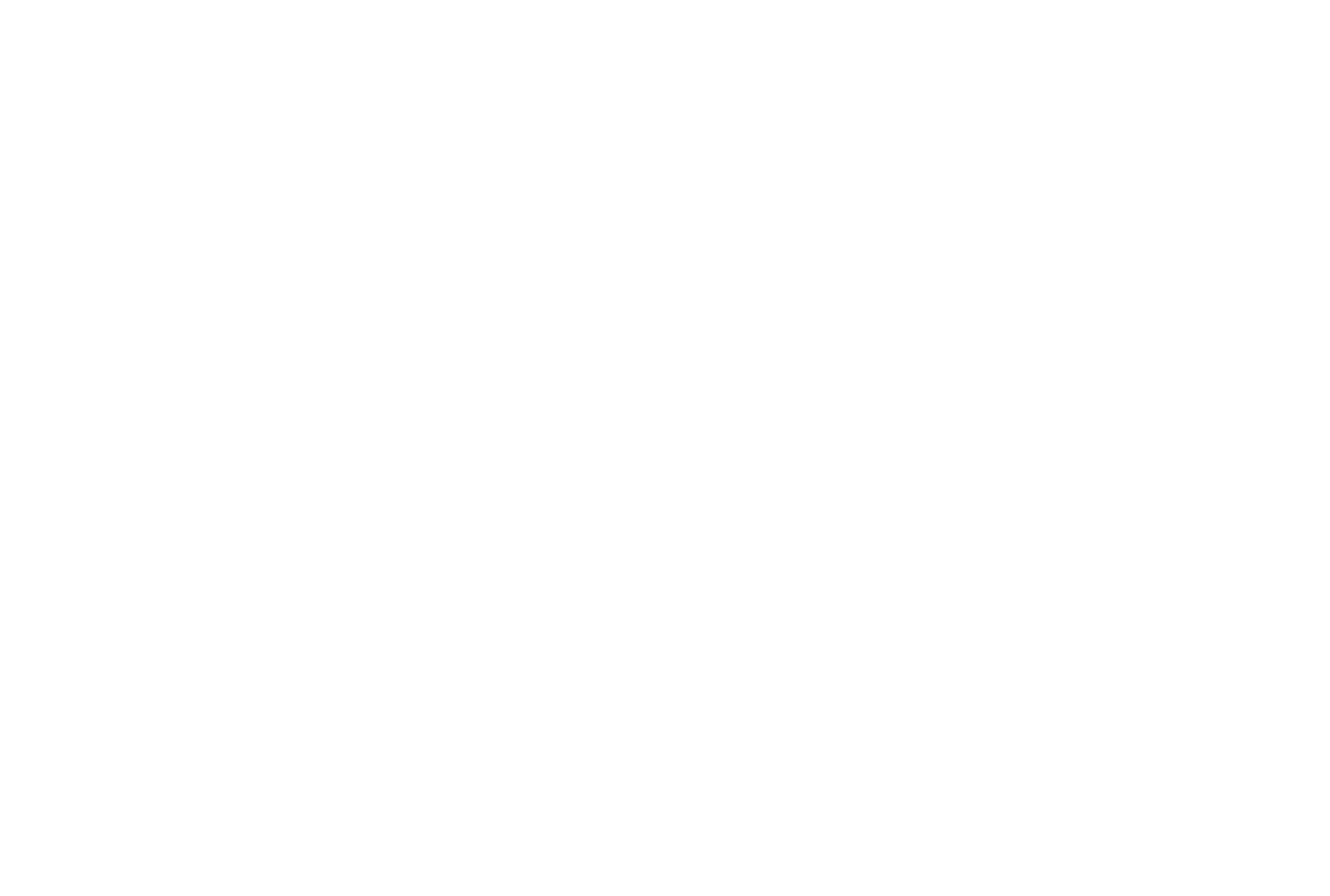

Figure S20. ${ }^{13} \mathrm{C}$ NMR of compound $2 \mathrm{f}$ in $\mathrm{CDCl}_{3}$ at $500 \mathrm{MHz}$ 


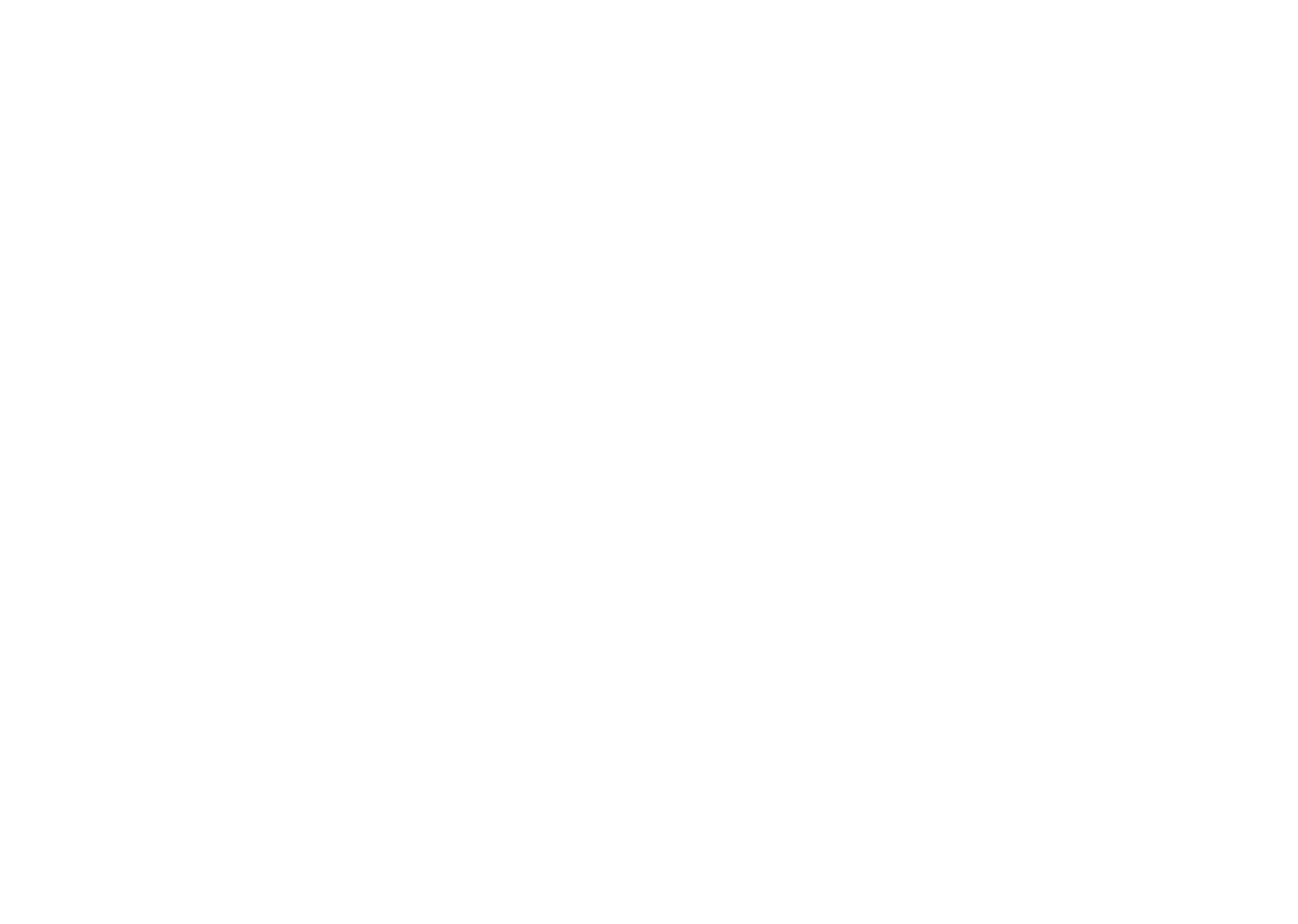

Figure S21. ${ }^{1} \mathrm{H}$ NMR of compound $2 \mathrm{~g}$ in $\mathrm{CDCl}_{3}$ at $500 \mathrm{MHz}$ 


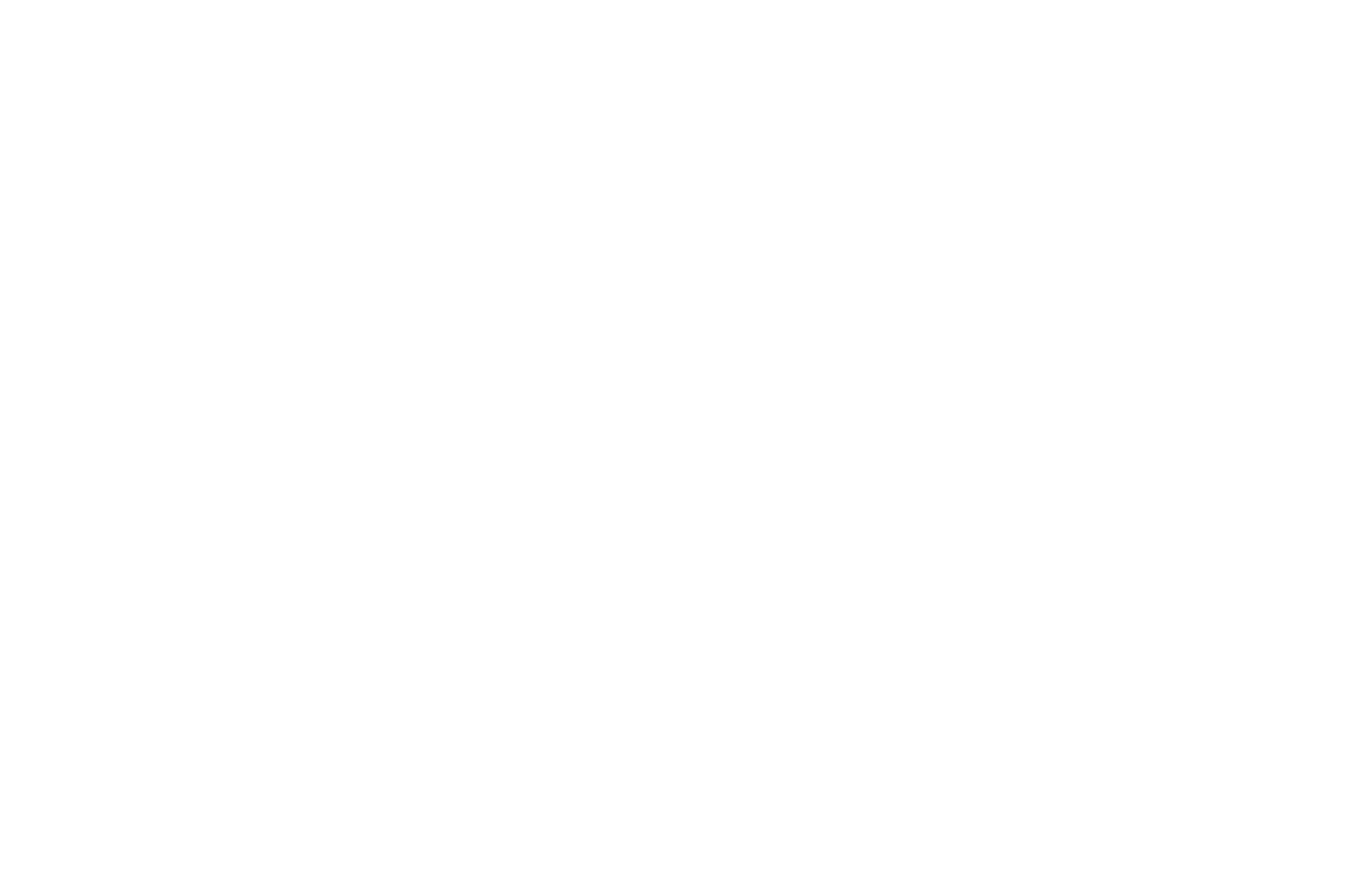

Figure S22. ${ }^{13} \mathrm{C} \mathrm{NMR}$ of compound $2 \mathrm{~g}$ in $\mathrm{CDCl}_{3}$ at $500 \mathrm{MHz}$ 


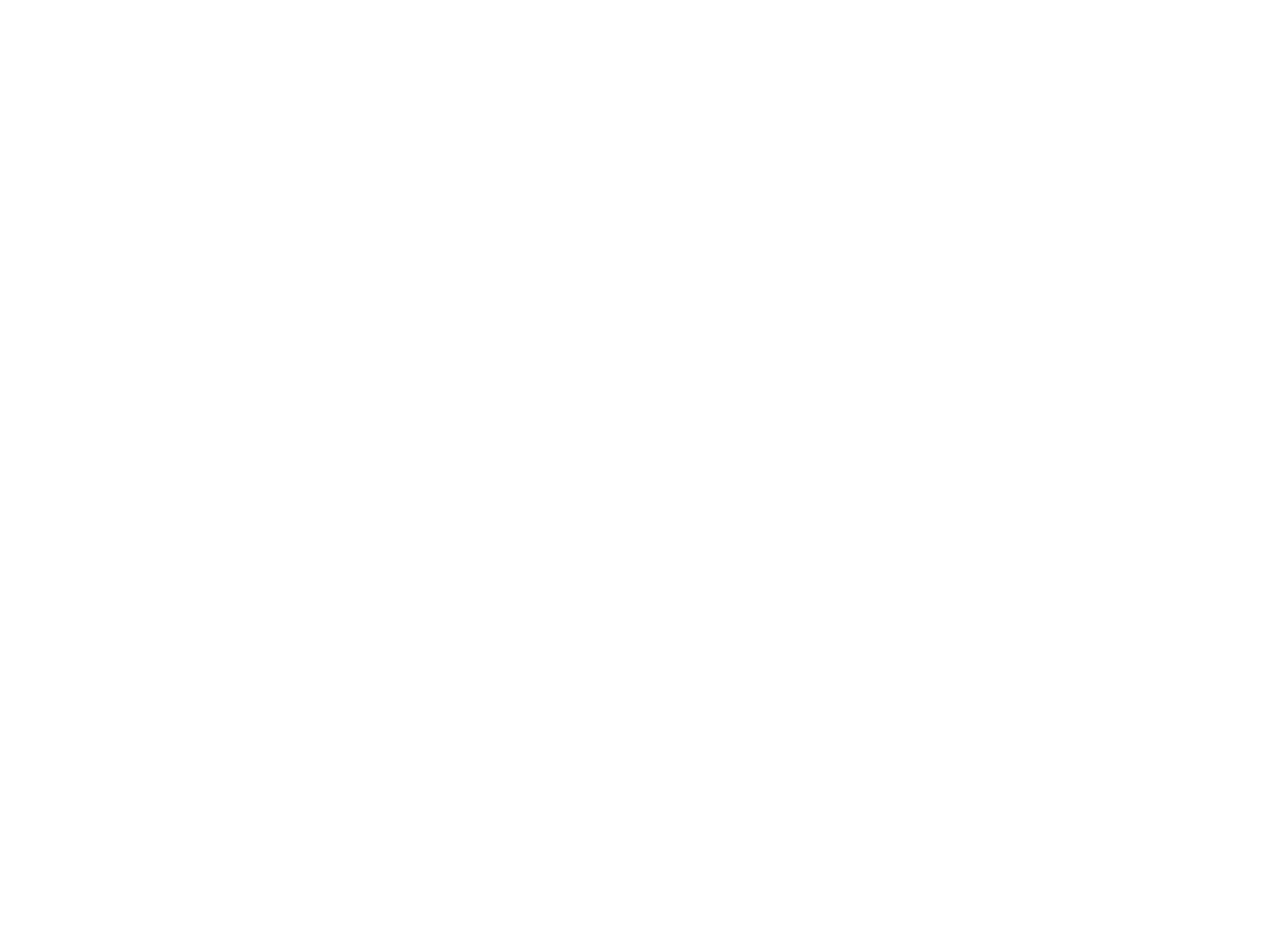

Figure S23. ${ }^{1} \mathrm{H}$ NMR of compound $\mathbf{2 h}$ in $\mathrm{CDCl}_{3}$ at $500 \mathrm{MHz}$ 


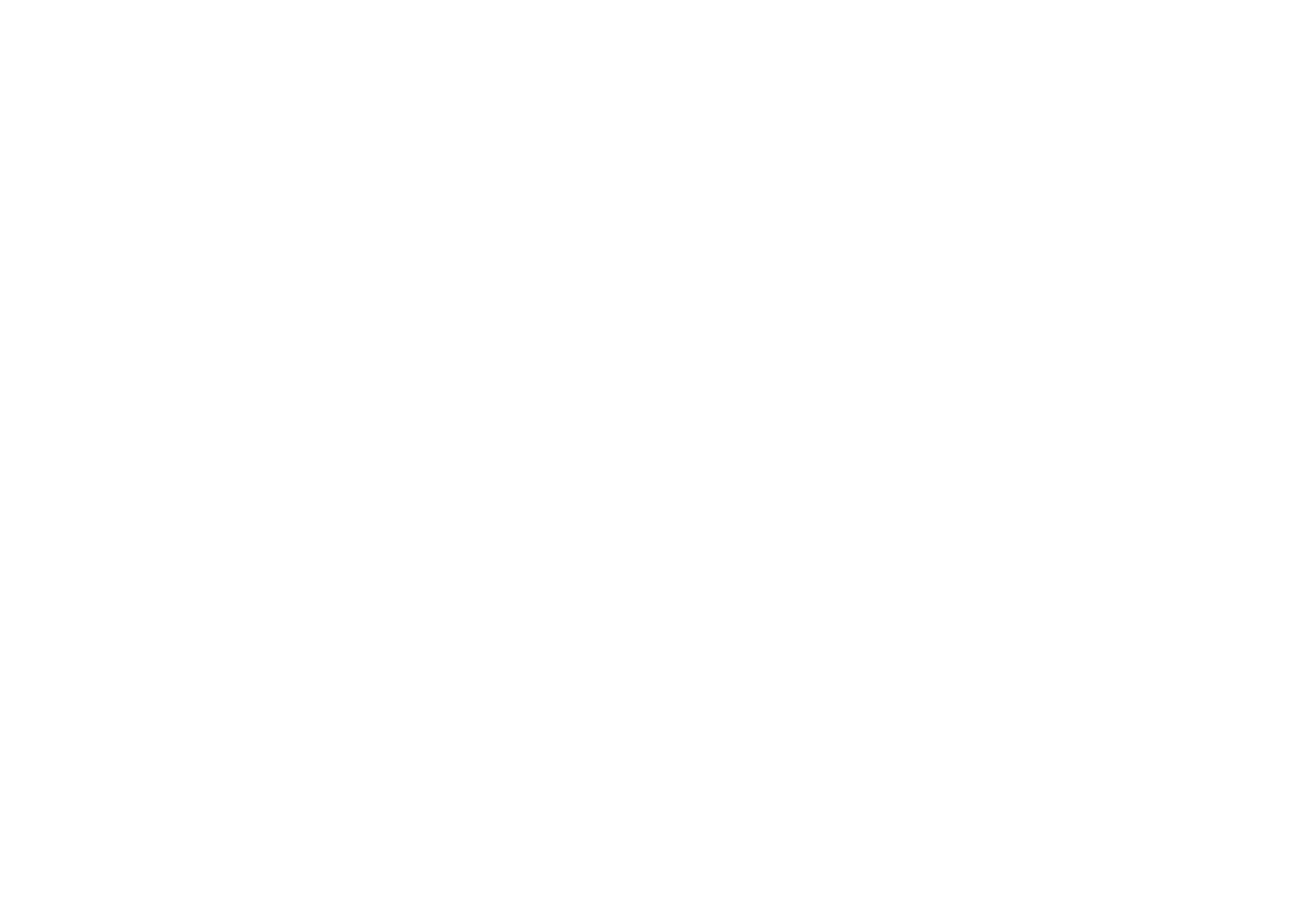

Figure S24. ${ }^{13} \mathrm{C} \mathrm{NMR}$ of compound $\mathbf{2 h}$ in $\mathrm{CDCl}_{3}$ at $500 \mathrm{MHz}$ 


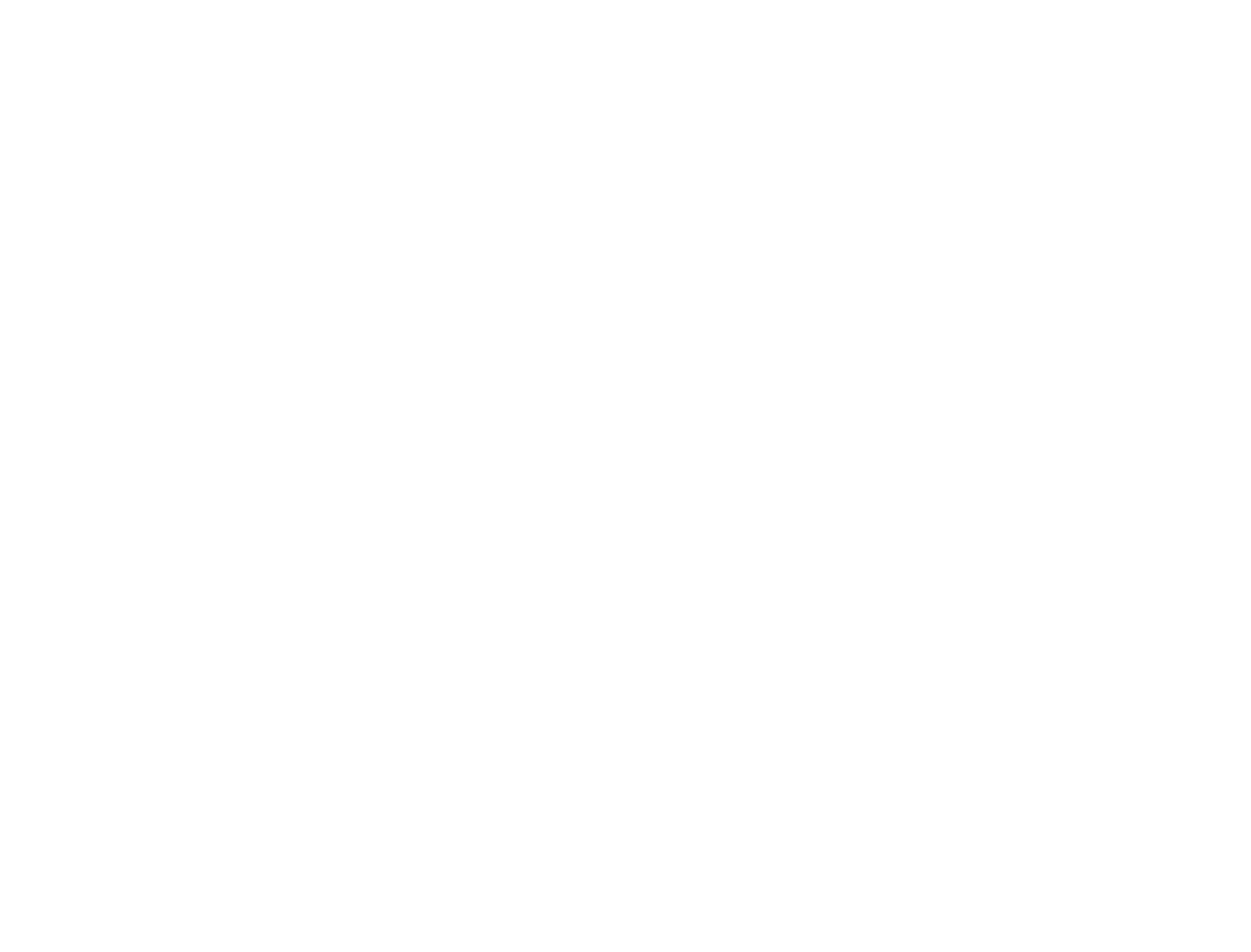

Figure S25. ${ }^{1} \mathrm{H} \mathrm{NMR}$ of compound $\mathbf{2 i}$ in $\mathrm{CDCl}_{3}$ at $500 \mathrm{MHz}$ 


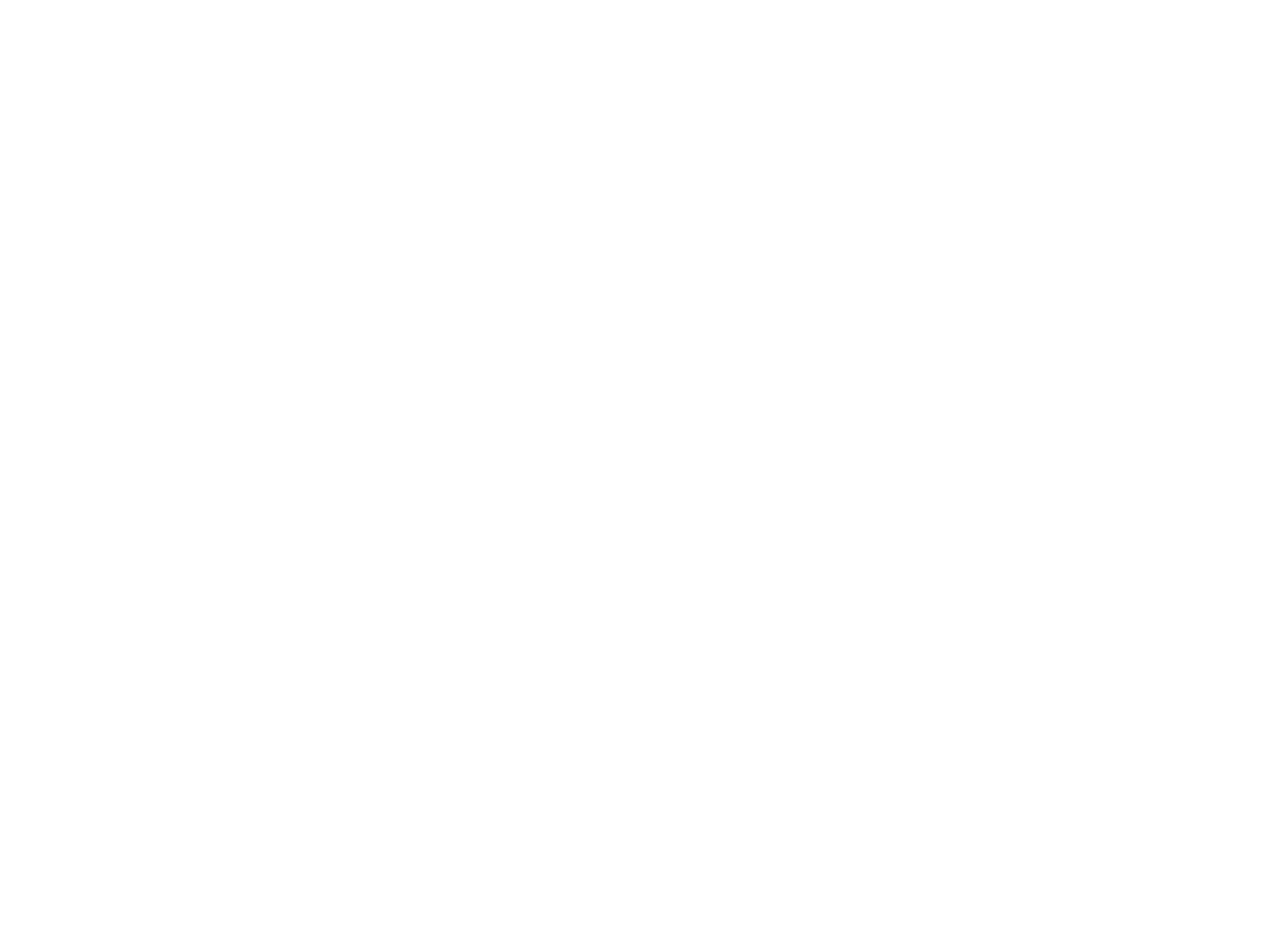

Figure S26. ${ }^{13} \mathrm{C}$ NMR of compound $2 \mathbf{i}$ in $\mathrm{CDCl}_{3}$ at $500 \mathrm{MHz}$ 


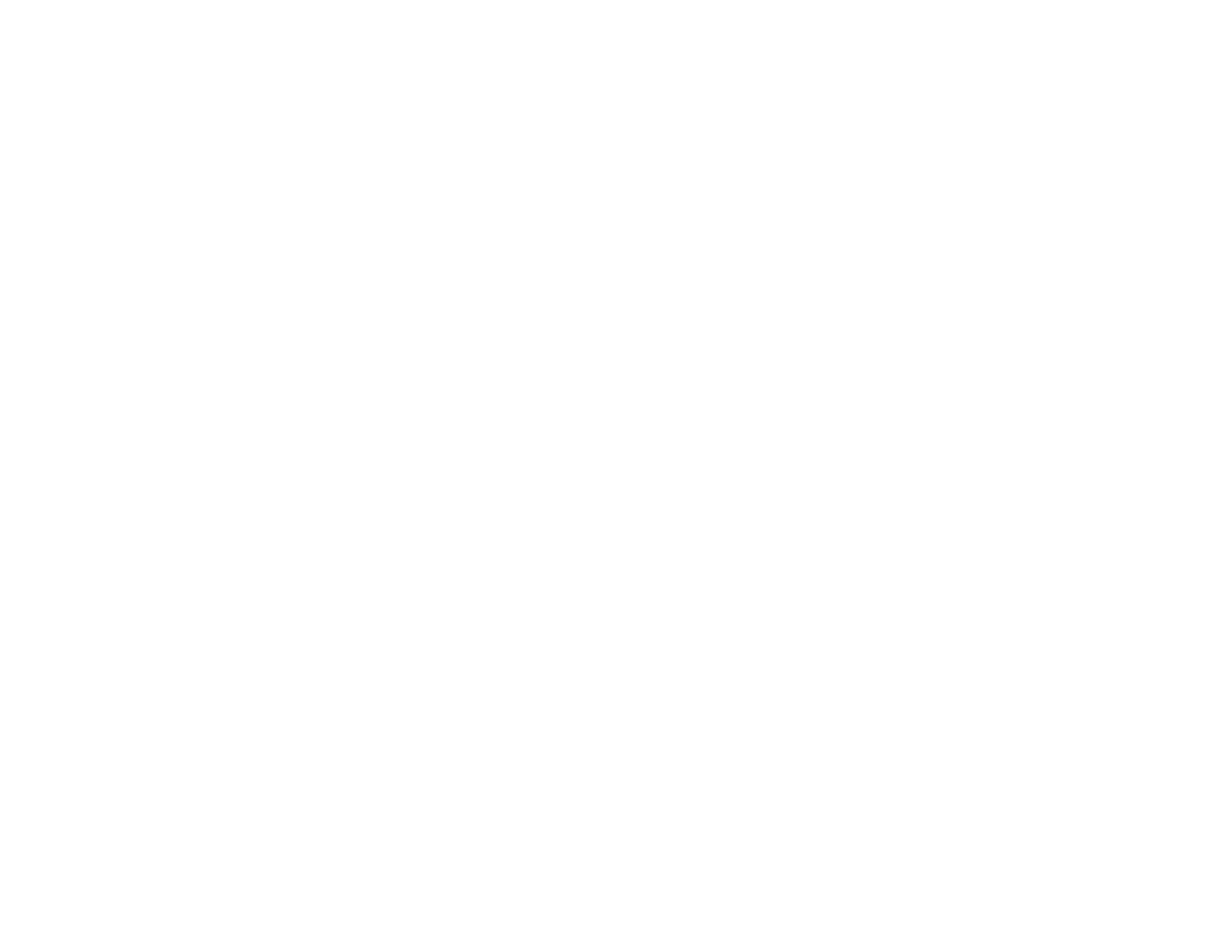

Figure S27. ${ }^{1} \mathrm{H}$ NMR of compound $\mathbf{2 j}$ in $\mathrm{D}_{2} \mathrm{O}$ at $500 \mathrm{MHz}$ 
${ }^{1} \mathrm{H}$ and ${ }^{13} \mathrm{C}$ NMR spectrum of compounds $4 \mathrm{a}-4 \mathrm{~d}$

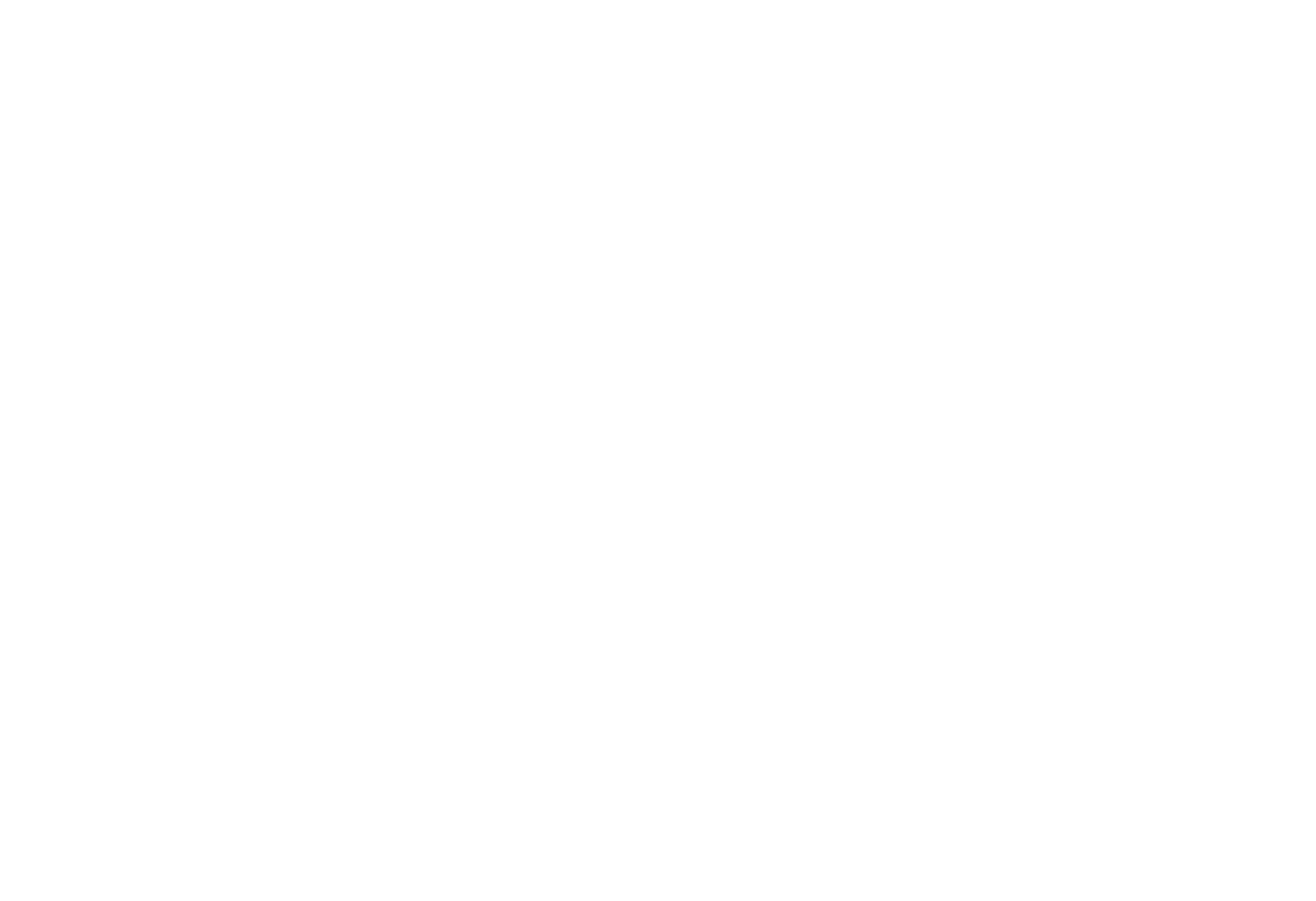

Figure S28. ${ }^{1} \mathrm{H} \mathrm{NMR}$ of compound $\mathbf{4 a}$ in $\mathrm{CDCl}_{3}$ at $500 \mathrm{MHz}$ 


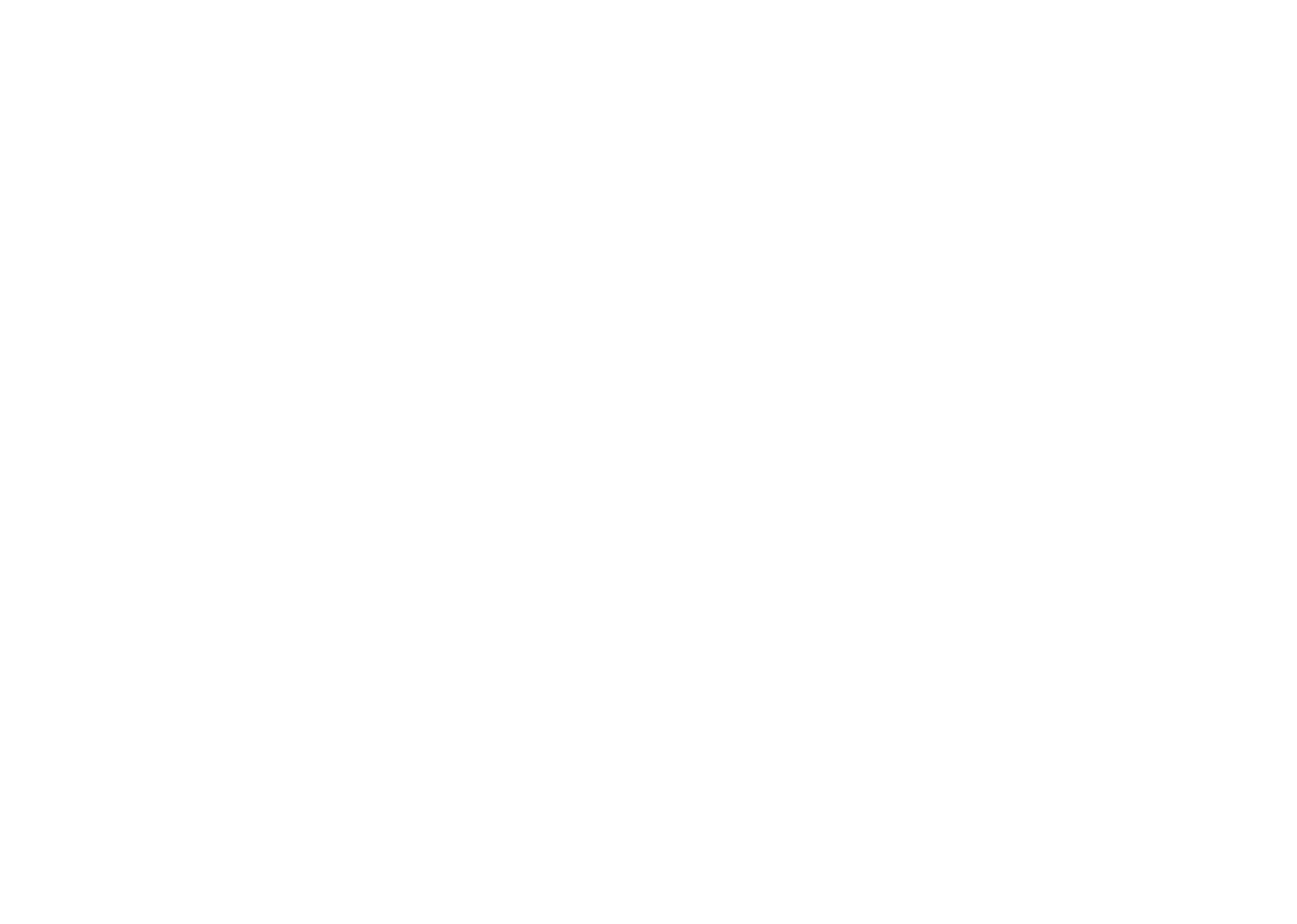

Figure S29. ${ }^{13} \mathrm{C}$ NMR of compound $4 \mathbf{a}$ in $\mathrm{CDCl}_{3}$ at $500 \mathrm{MHz}$ 
SpinWorks 4: PROTON CDCl3 E: \data CUG

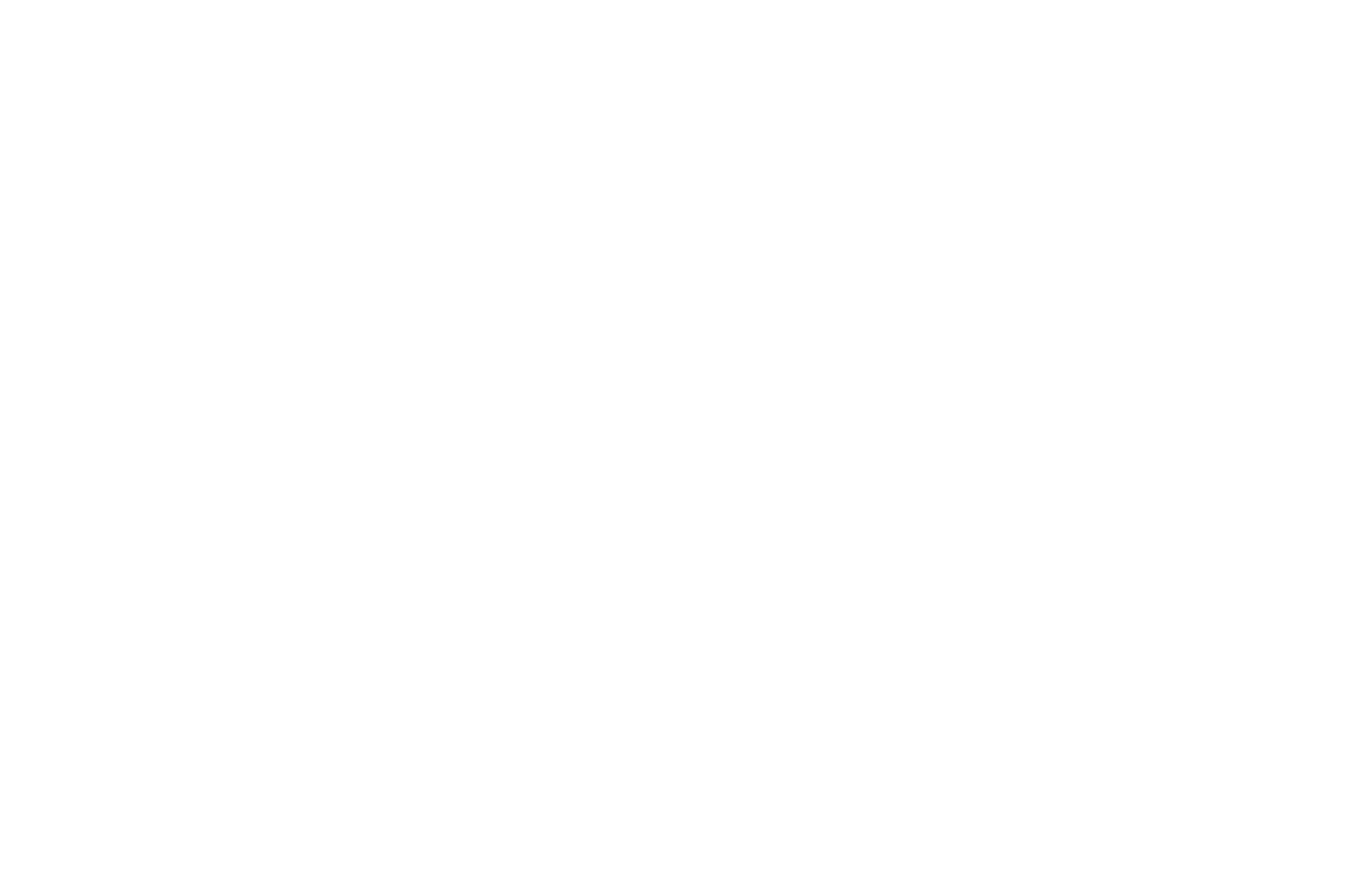

Figure S30. ${ }^{1} \mathrm{H}$ NMR of compound $\mathbf{4 b}$ in $\mathrm{CDCl}_{3}$ at $500 \mathrm{MHz}$ 


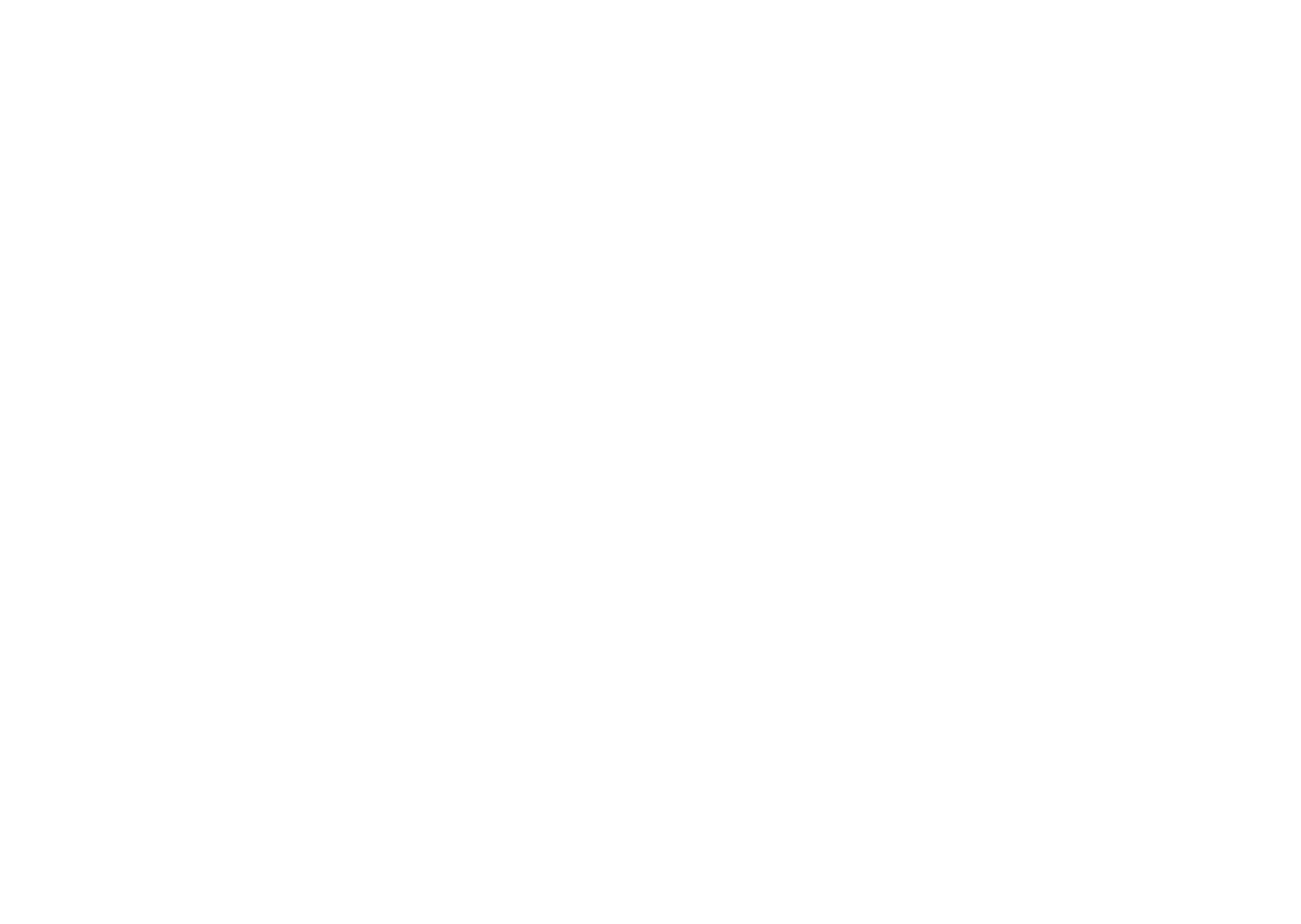

Figure S31. ${ }^{13} \mathrm{C}$ NMR of compound $\mathbf{4 b}$ in $\mathrm{CDCl}_{3}$ at $500 \mathrm{MHz}$ 


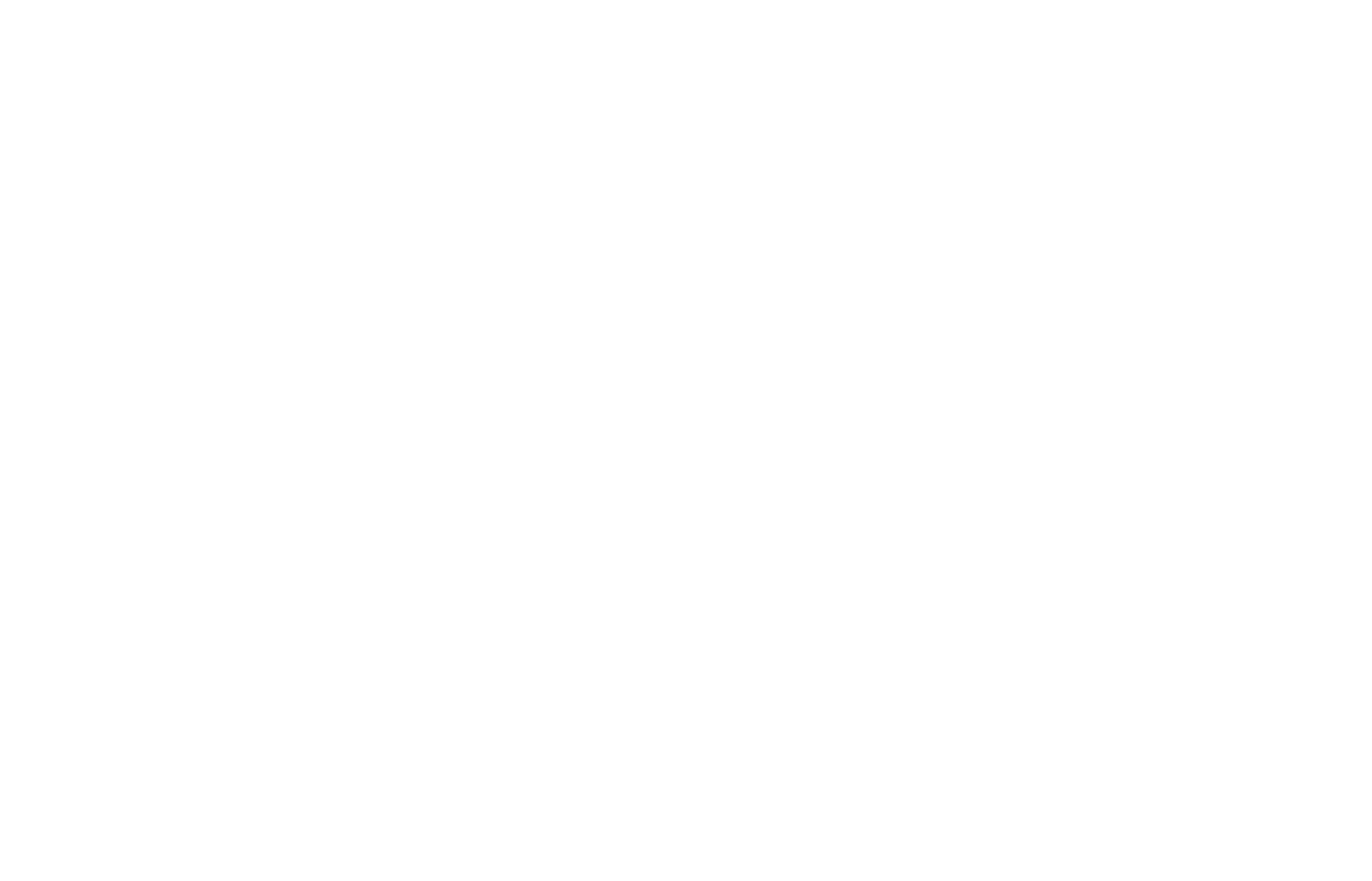

Figure S32. ${ }^{1} \mathrm{H}$ NMR of compound $4 \mathbf{c}$ in $\mathrm{CDCl}_{3}$ at $500 \mathrm{MHz}$ 


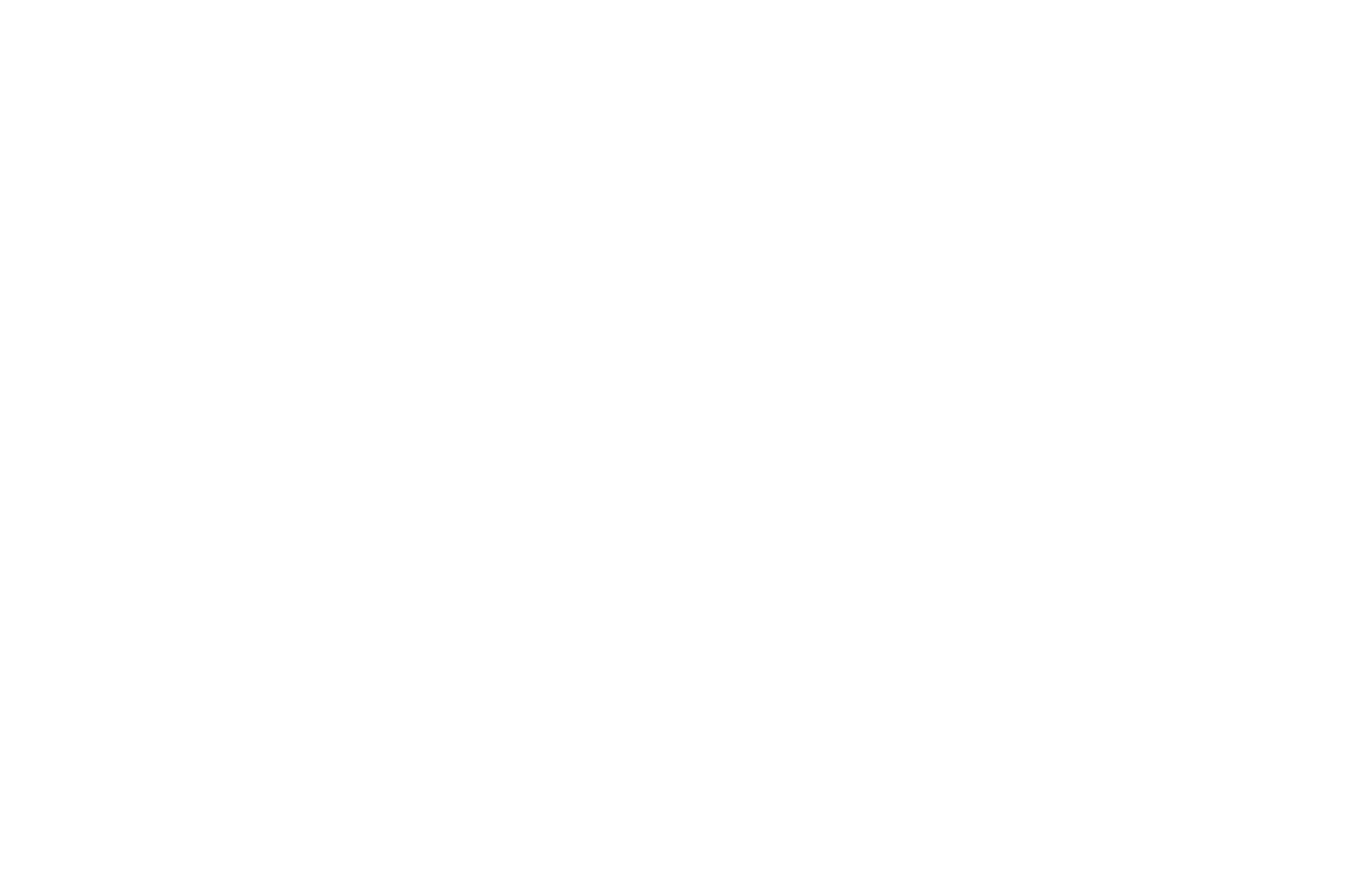

Figure S33. ${ }^{13} \mathrm{C}$ NMR of compound $4 \mathbf{c}$ in $\mathrm{CDCl}_{3}$ at $500 \mathrm{MHz}$ 


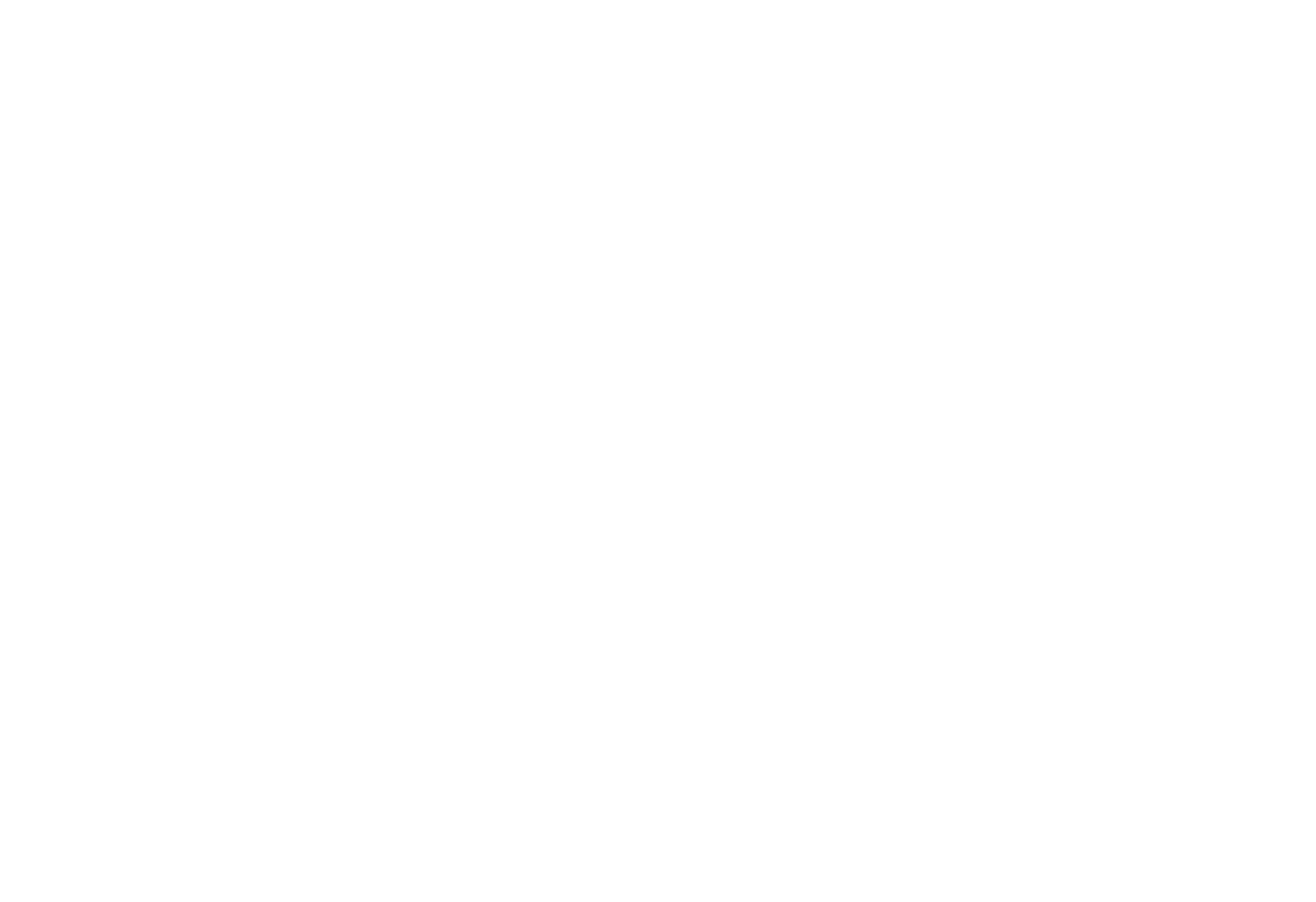

Figure S34. ${ }^{1} \mathrm{H}$ NMR of compound $4 \mathbf{d}$ in $\mathrm{CDCl}_{3}$ at $500 \mathrm{MHz}$ 
${ }^{1} \mathrm{H}$ and ${ }^{13} \mathrm{C}$ NMR spectrum of compounds $5 \mathrm{~b}-14 \mathrm{~b}$

SpinWorks 4: DMABT

PROTON CDCl3 E:\data CUG

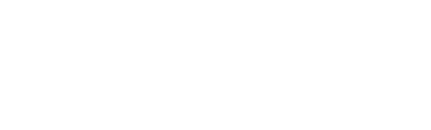

$\underset{\sim}{\stackrel{\leftrightarrow}{\omega}}$

$\overbrace{\mathrm{OH}}^{\mathrm{MOMO}} \mathrm{OH}$

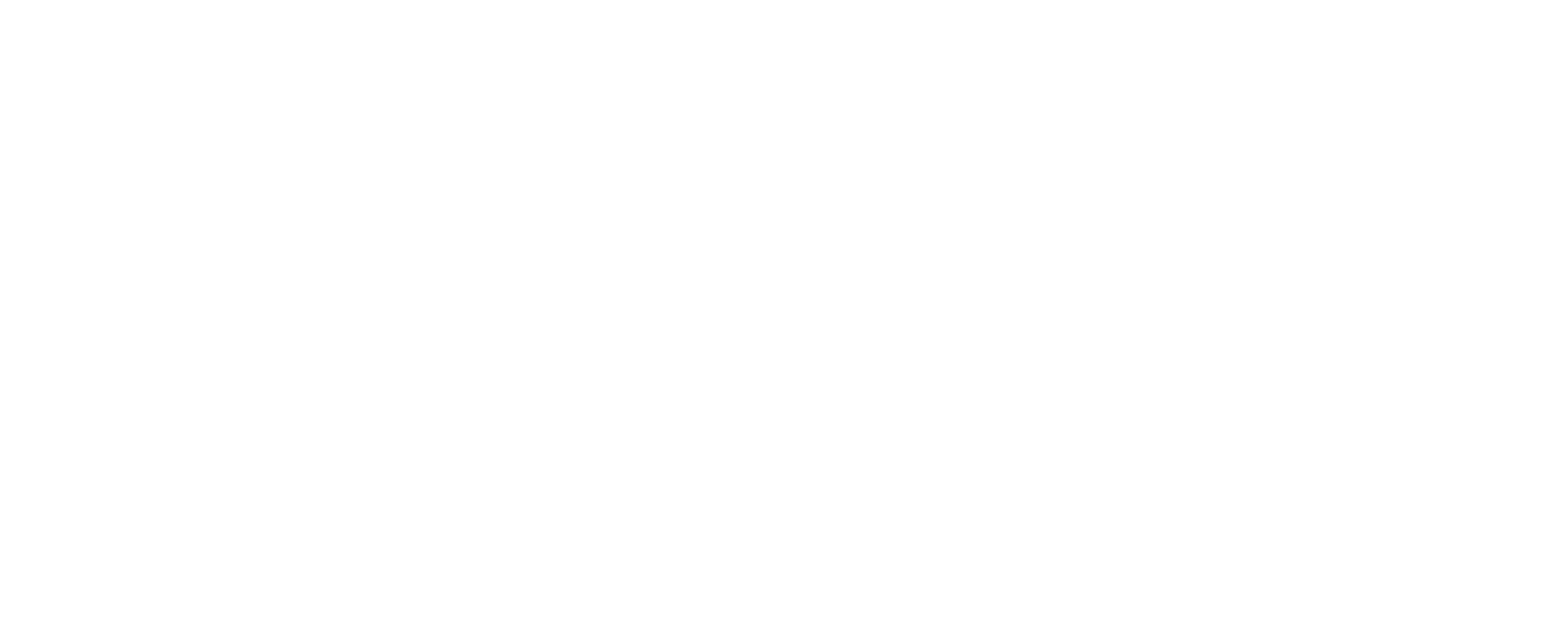

Figure S35. ${ }^{1} \mathrm{H}$ NMR of compound $\mathbf{5 b}$ in $\mathrm{CDCl}_{3}$ at $500 \mathrm{MHz}$ 
SpinWorks 4: PROTON CDCl3 E: \data CUG

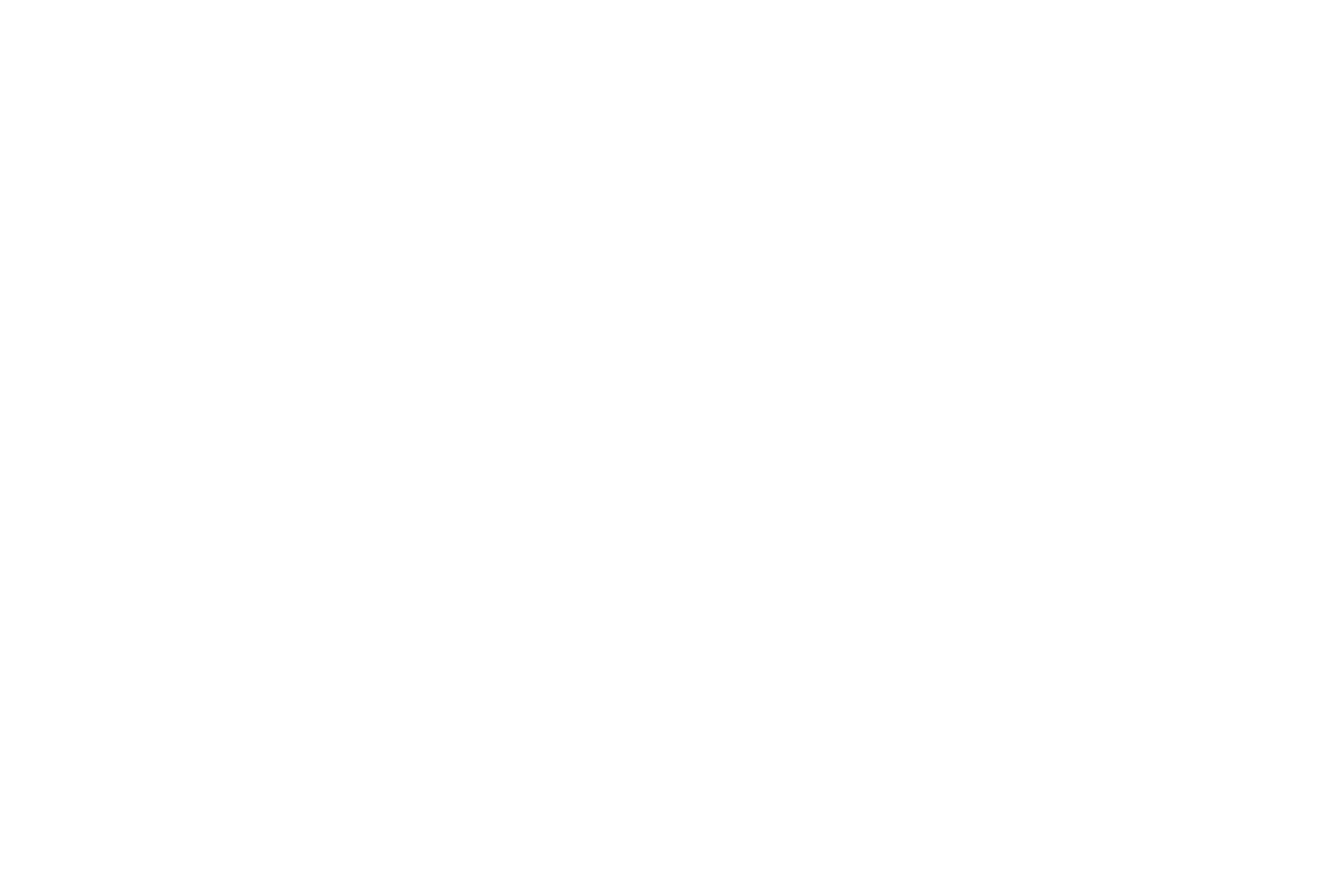

Figure S36. ${ }^{1} \mathrm{H} \mathrm{NMR}$ of compound $\mathbf{6 b}$ in $\mathrm{CDCl}_{3}$ at $500 \mathrm{MHz}$ 


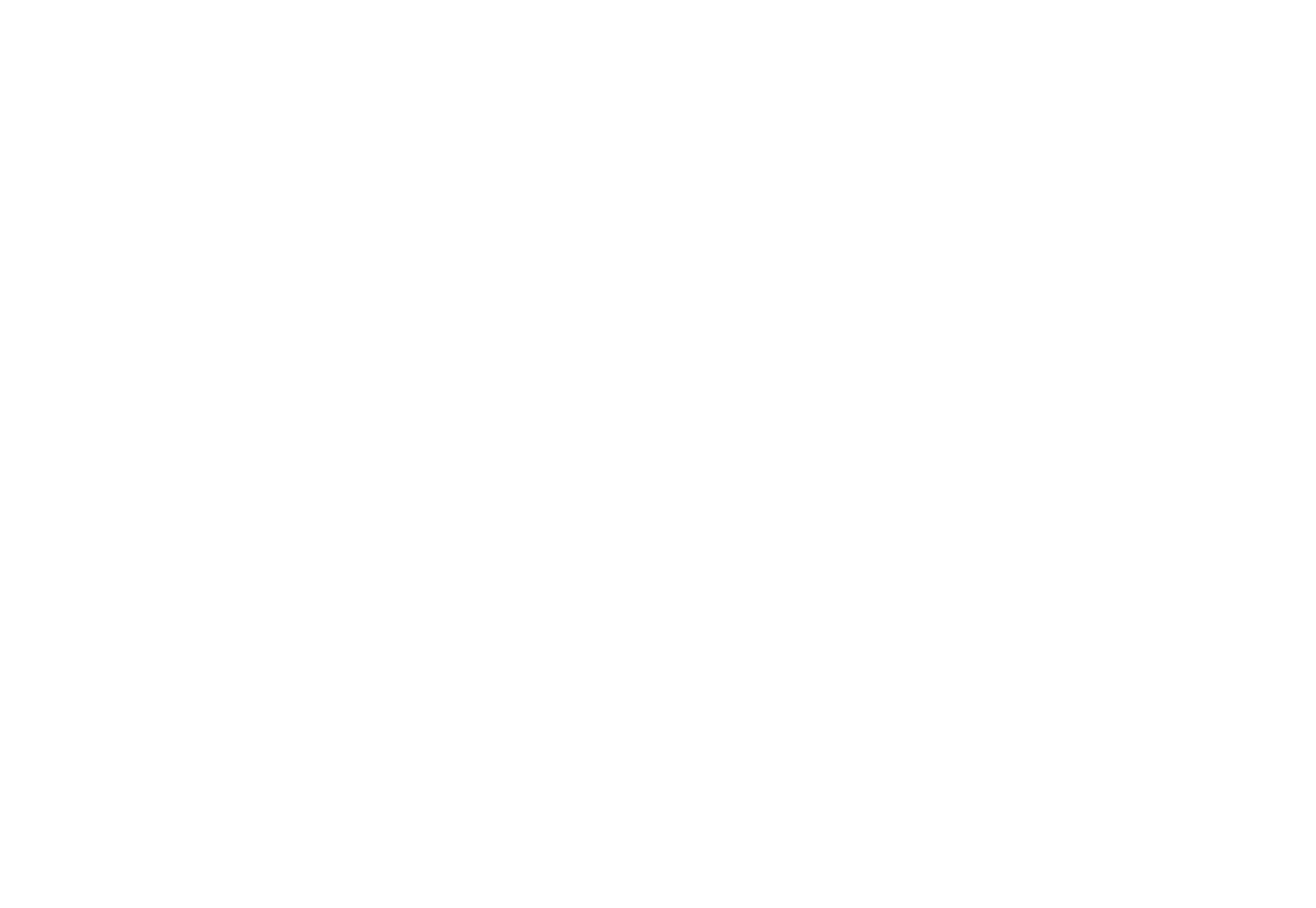

Figure S37. ${ }^{1} \mathrm{H}$ NMR of compound $7 \mathbf{b}$ in $\mathrm{CDCl}_{3}$ at $500 \mathrm{MHz}$ 
SpinWorks 4: PROTON CDCl3 E: Idata CUG

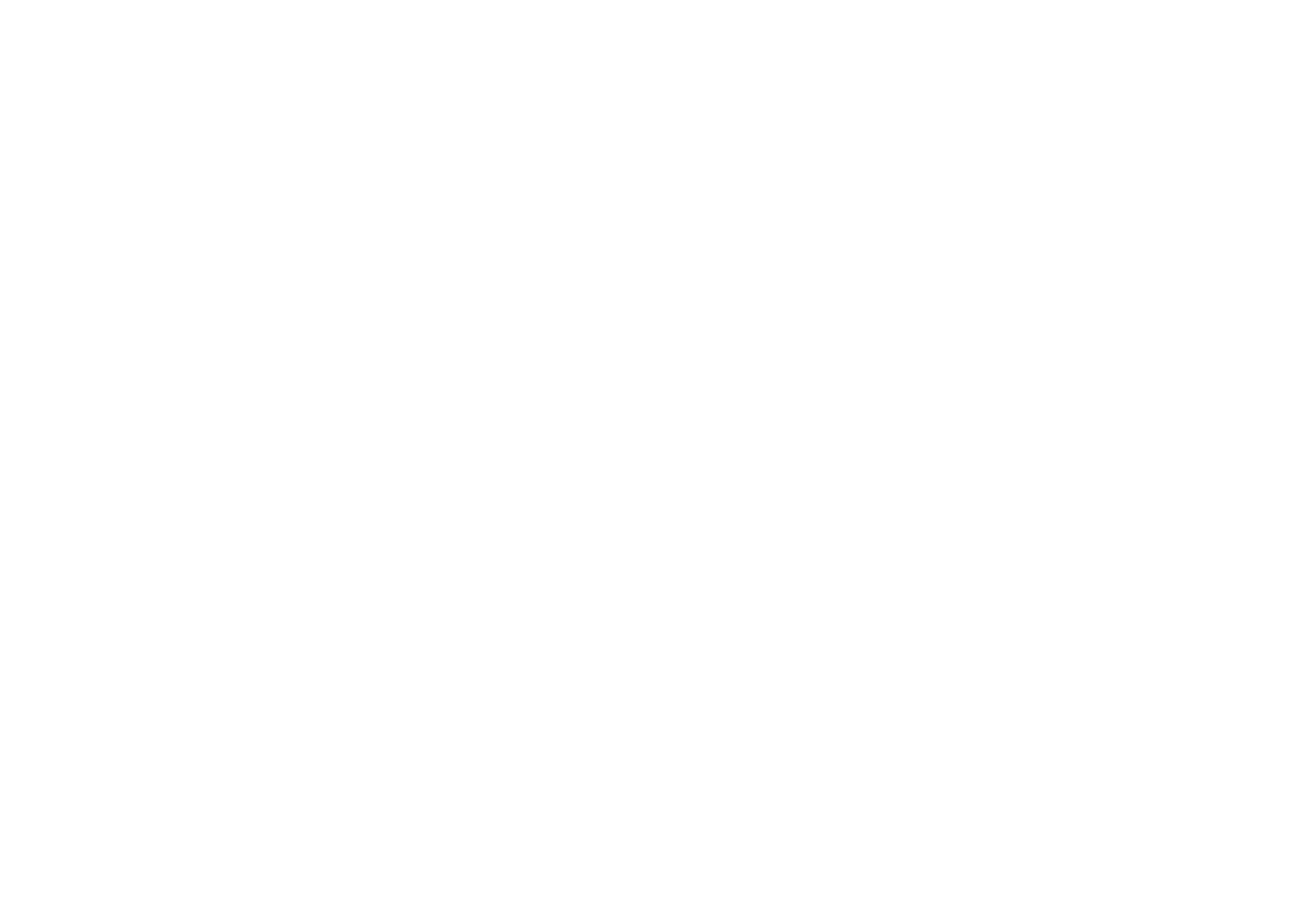

Figure S38. ${ }^{1} \mathrm{H}$ NMR of compound $\mathbf{8 b}$ in $\mathrm{CDCl}_{3}$ at $500 \mathrm{MHz}$ 


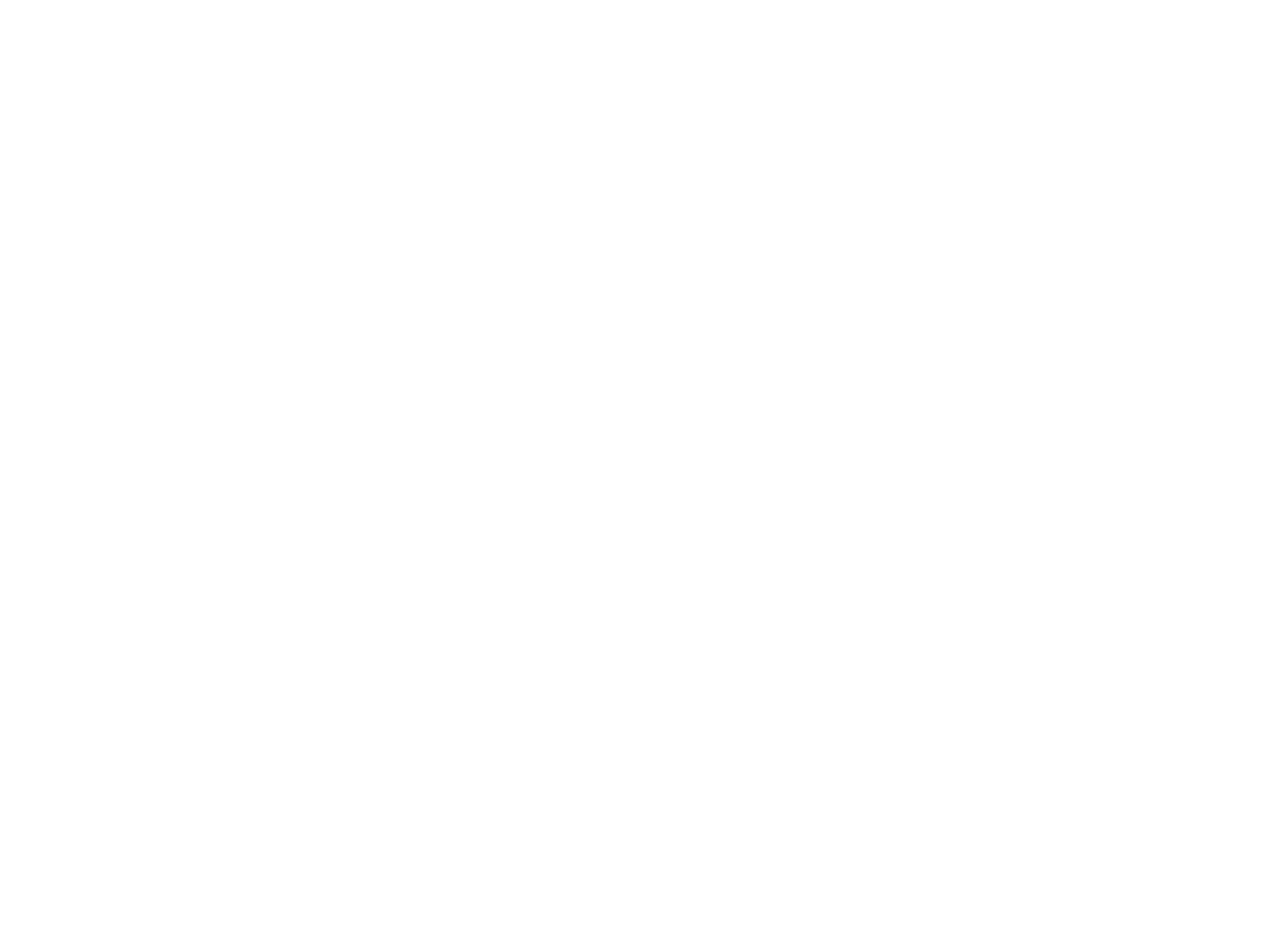

Figure S39. ${ }^{13} \mathrm{C}$ NMR of compound $\mathbf{8 b}$ in $\mathrm{CDCl}_{3}$ at $500 \mathrm{MHz}$ 


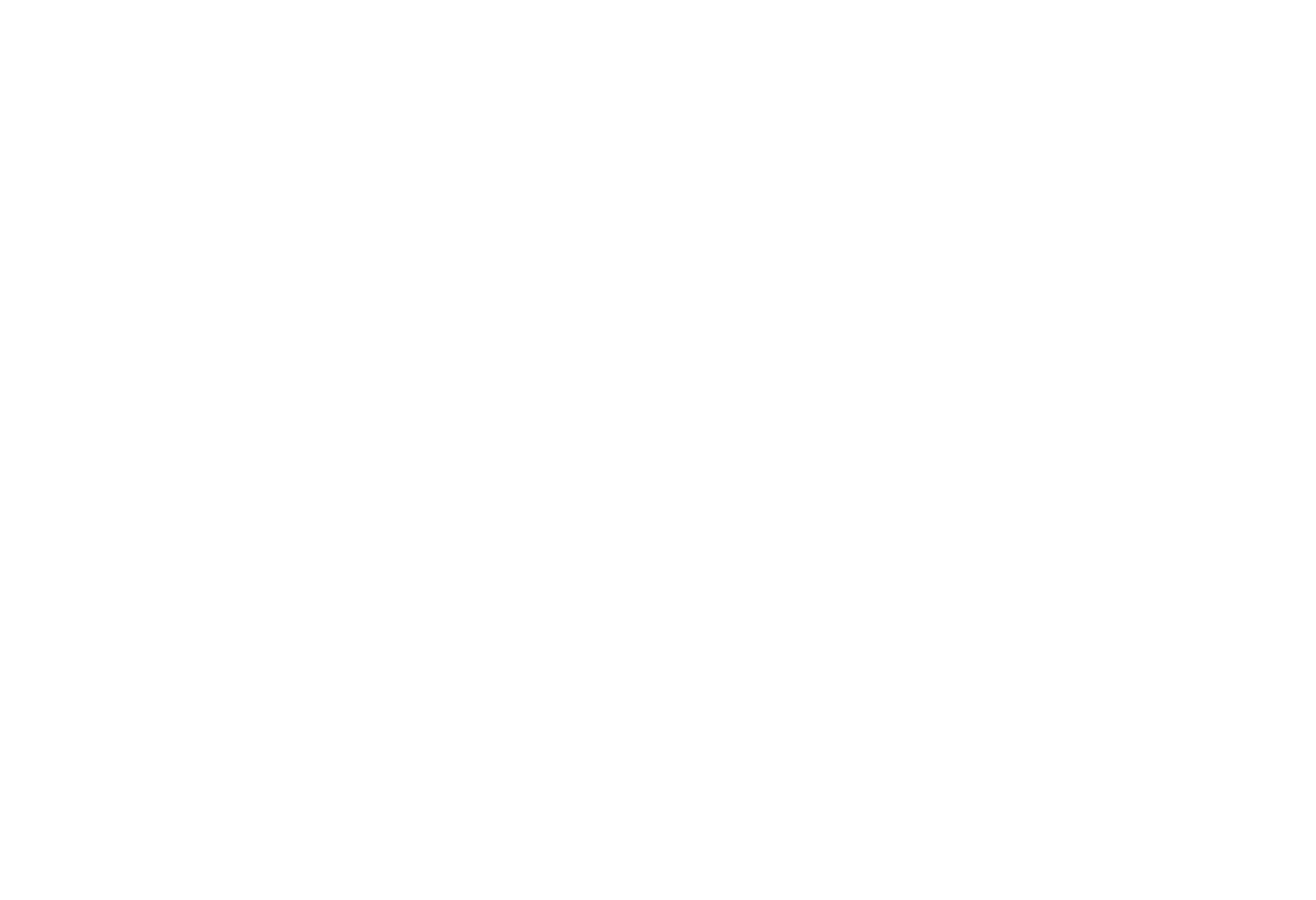

Figure S40. ${ }^{1} \mathrm{H} \mathrm{NMR}$ of compound $\mathbf{9 b}$ in $\mathrm{CDCl}_{3}$ at $500 \mathrm{MHz}$ 


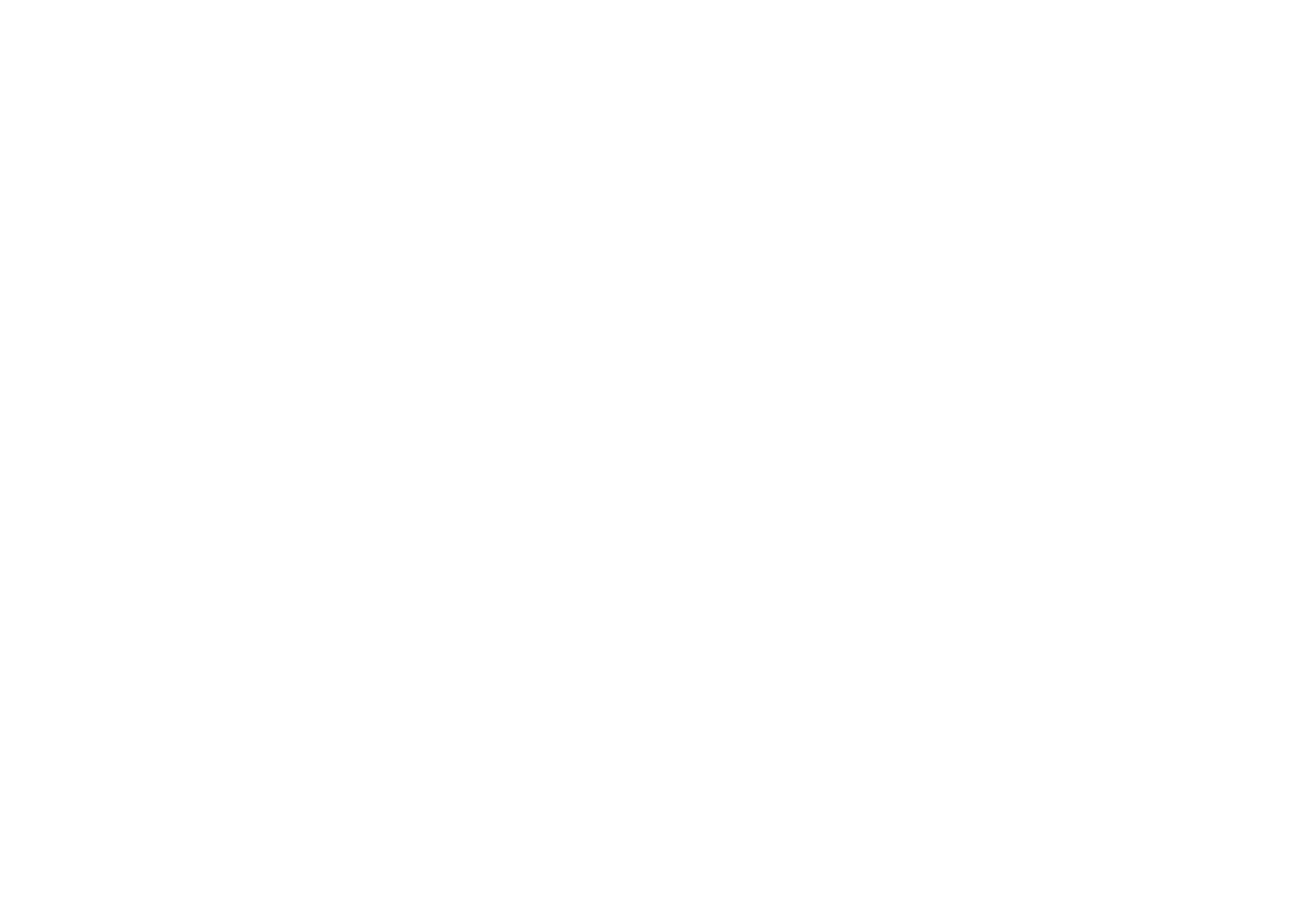

Figure $\mathbf{S 4 1 .}{ }^{13} \mathrm{C}$ NMR of compound $9 \mathrm{~b}$ in $\mathrm{CDCl}_{3}$ at $500 \mathrm{MHz}$ 


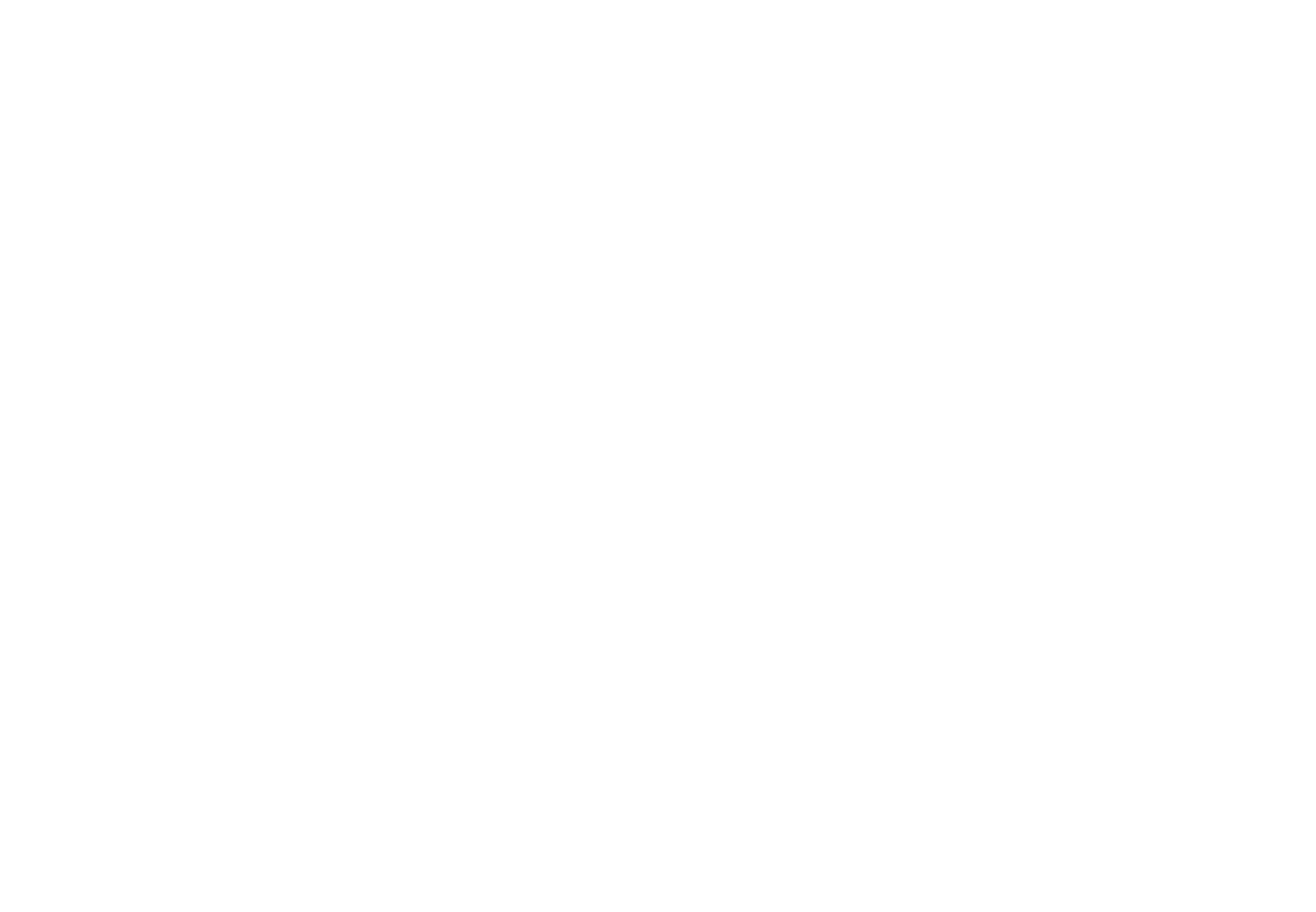

Figure S42. ${ }^{1} \mathrm{H}$ NMR of compound $\mathbf{1 0 b}$ in $\mathrm{CDCl}_{3}$ at $500 \mathrm{MHz}$ 


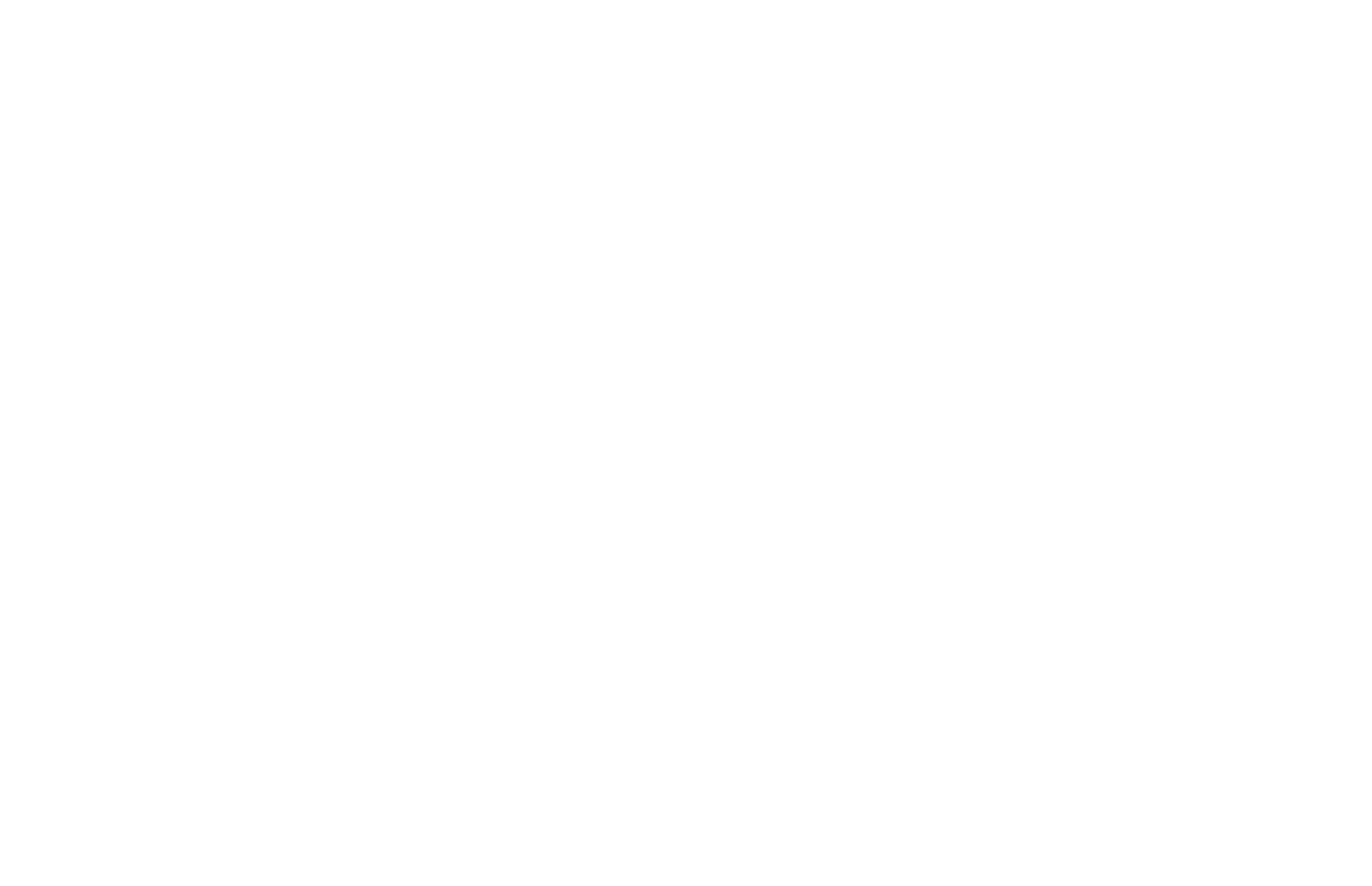

Figure S43. ${ }^{13} \mathrm{C}$ NMR of compound $\mathbf{1 0 b}$ in $\mathrm{CDCl}_{3}$ at $500 \mathrm{MHz}$ 


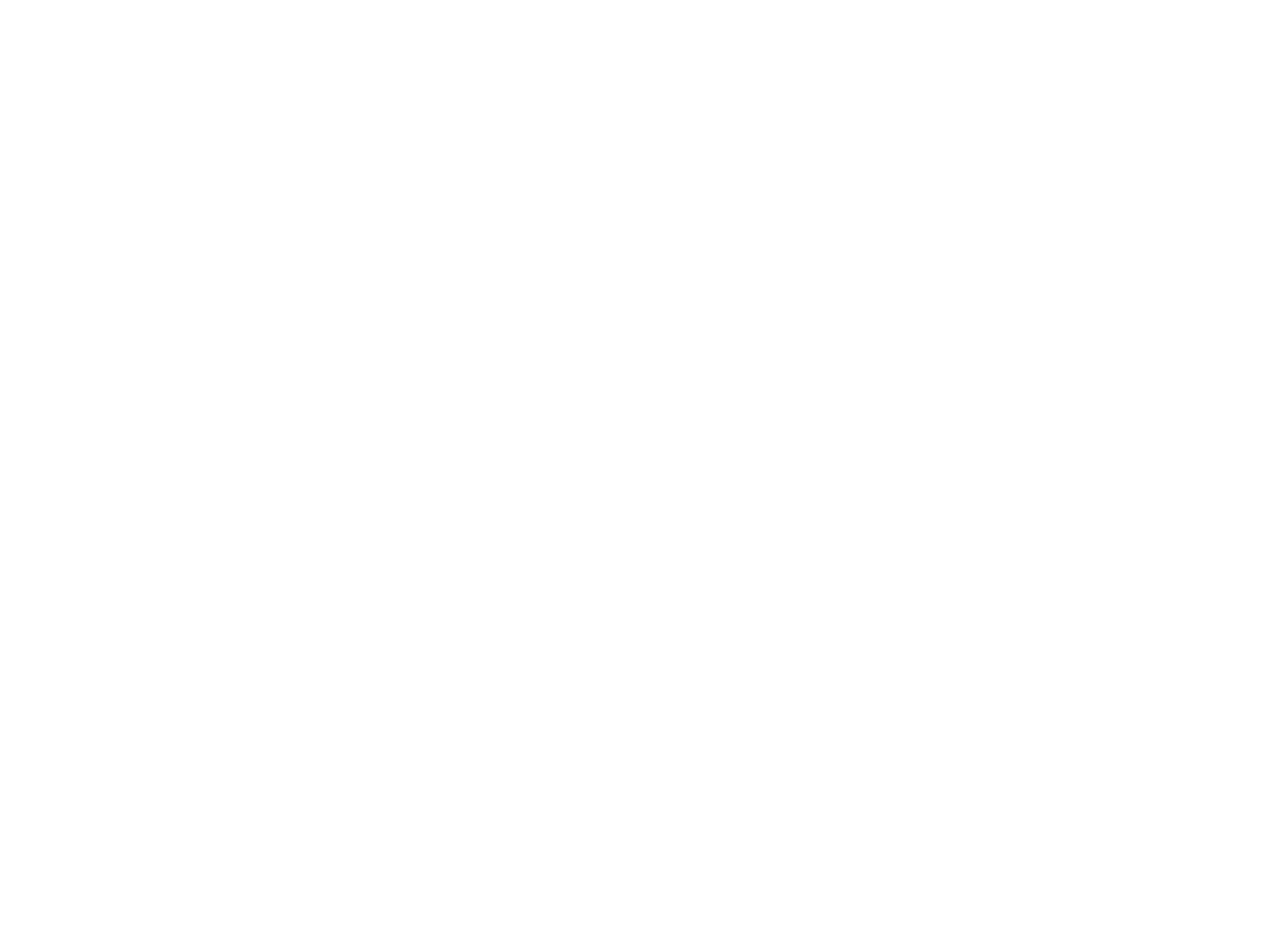

Figure S44. ${ }^{1} \mathrm{H}$ of compound $11 \mathrm{~b}$ in $\mathrm{CDCl}_{3}$ at $500 \mathrm{MHz}$ 


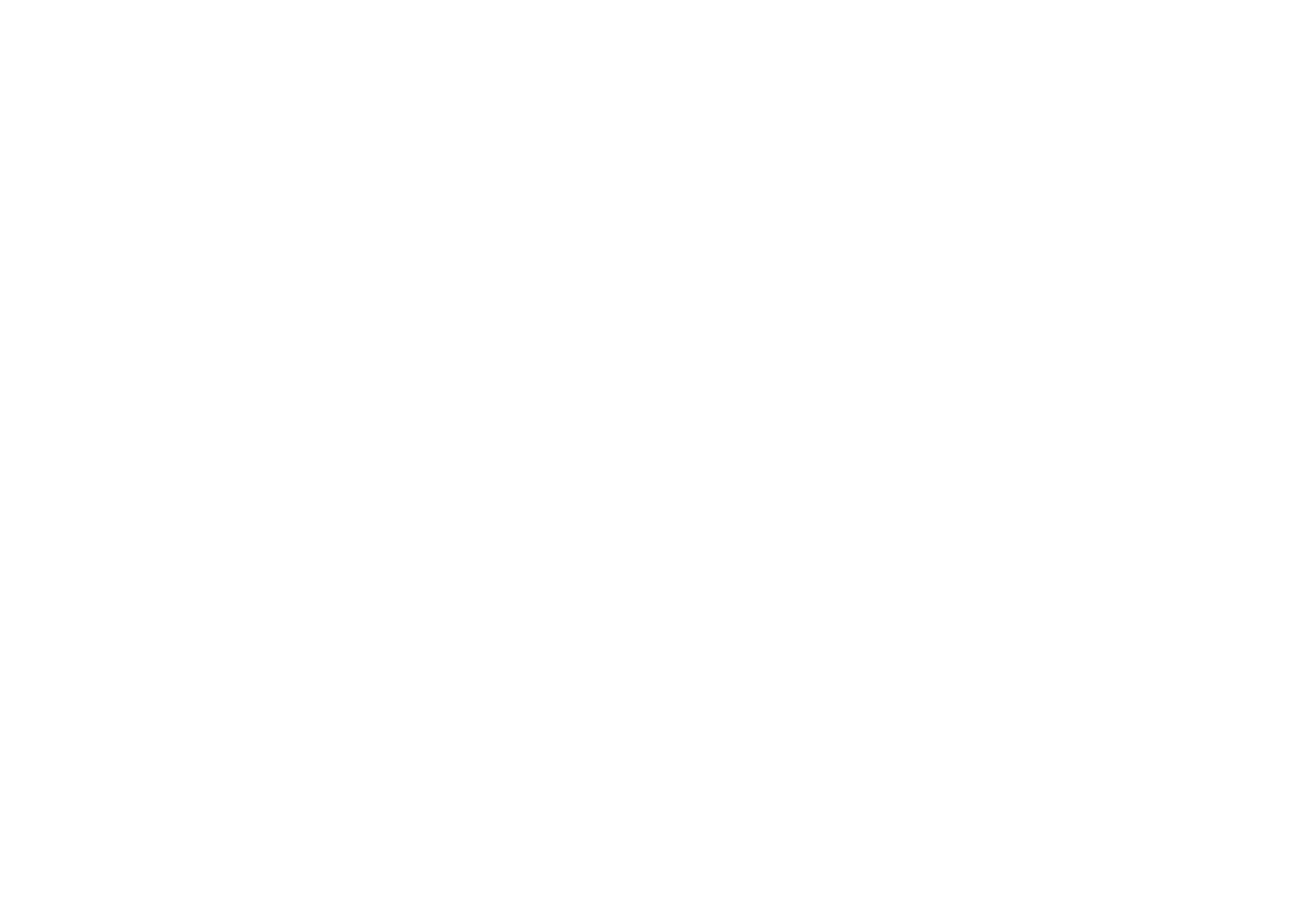

Figure S45. ${ }^{13} \mathrm{C}$ NMR of compound $\mathbf{1 1 b}$ in $\mathrm{CDCl}_{3}$ at $500 \mathrm{MHz}$ 


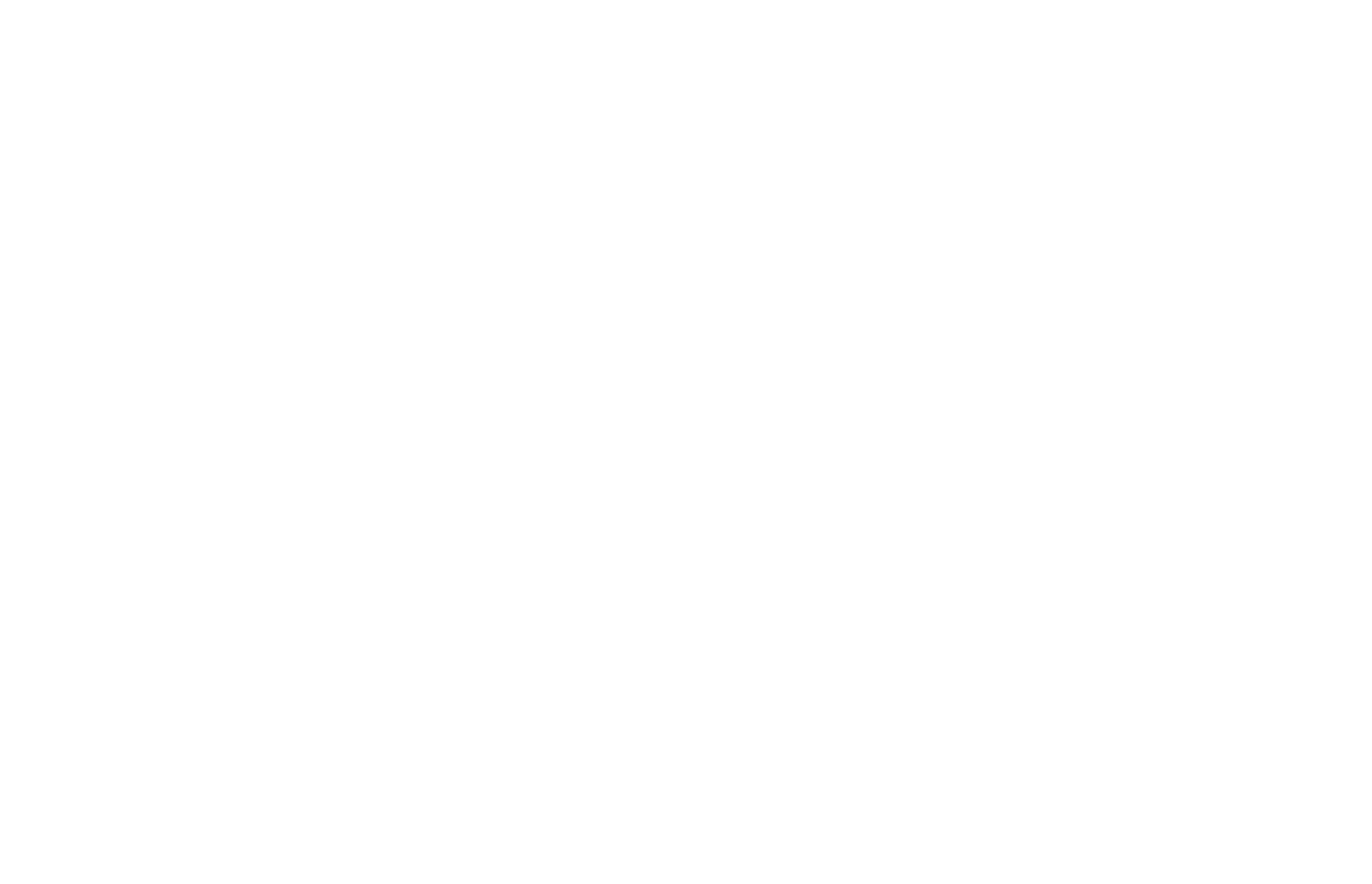

Figure S46. ${ }^{1} \mathrm{H}$ NMR of compound $\mathbf{1 3 b}$ in $\mathrm{CDCl}_{3}$ at $500 \mathrm{MHz}$ 


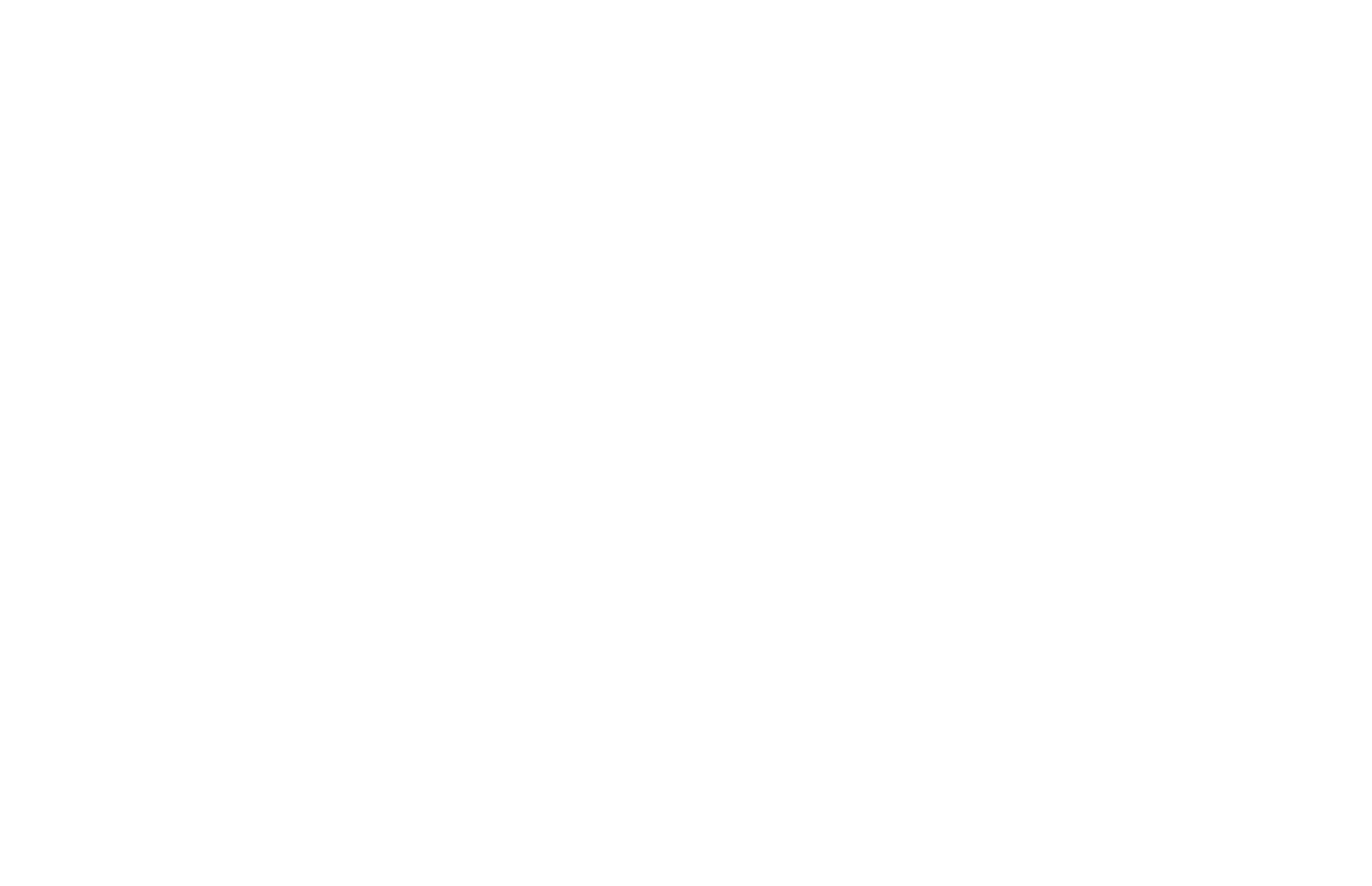

Figure S47. ${ }^{13} \mathrm{C}$ NMR of compound $\mathbf{1 3 b}$ in $\mathrm{CDCl}_{3}$ at $500 \mathrm{MHz}$ 


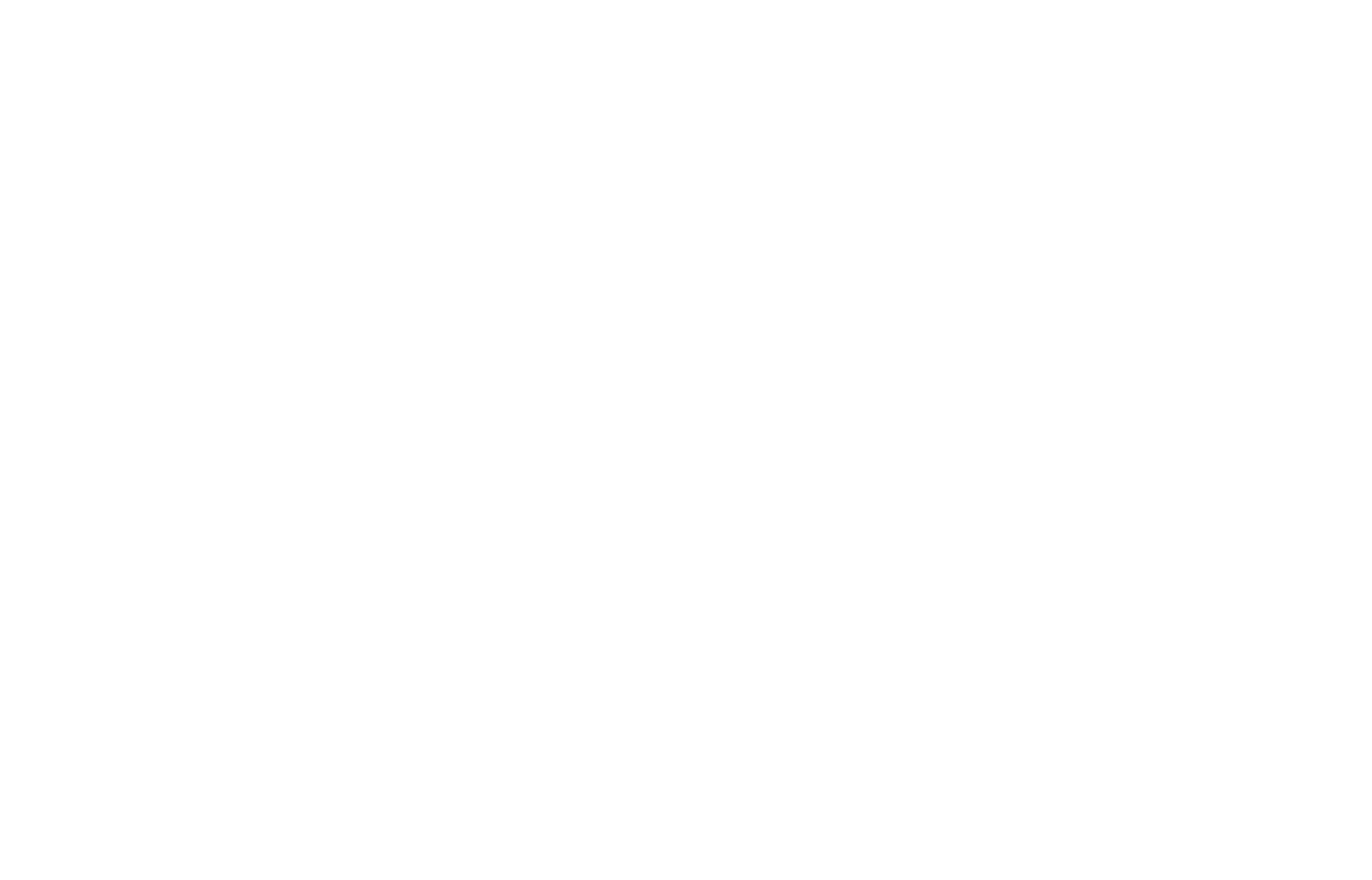

Figure S48: ${ }^{1} \mathrm{H}$ NMR of compound $14 \mathbf{b}$ in $\mathrm{D}_{2} \mathrm{O} / \mathrm{CD}_{3} \mathrm{OD}(19: 1)$ at $500 \mathrm{MHz}$ 


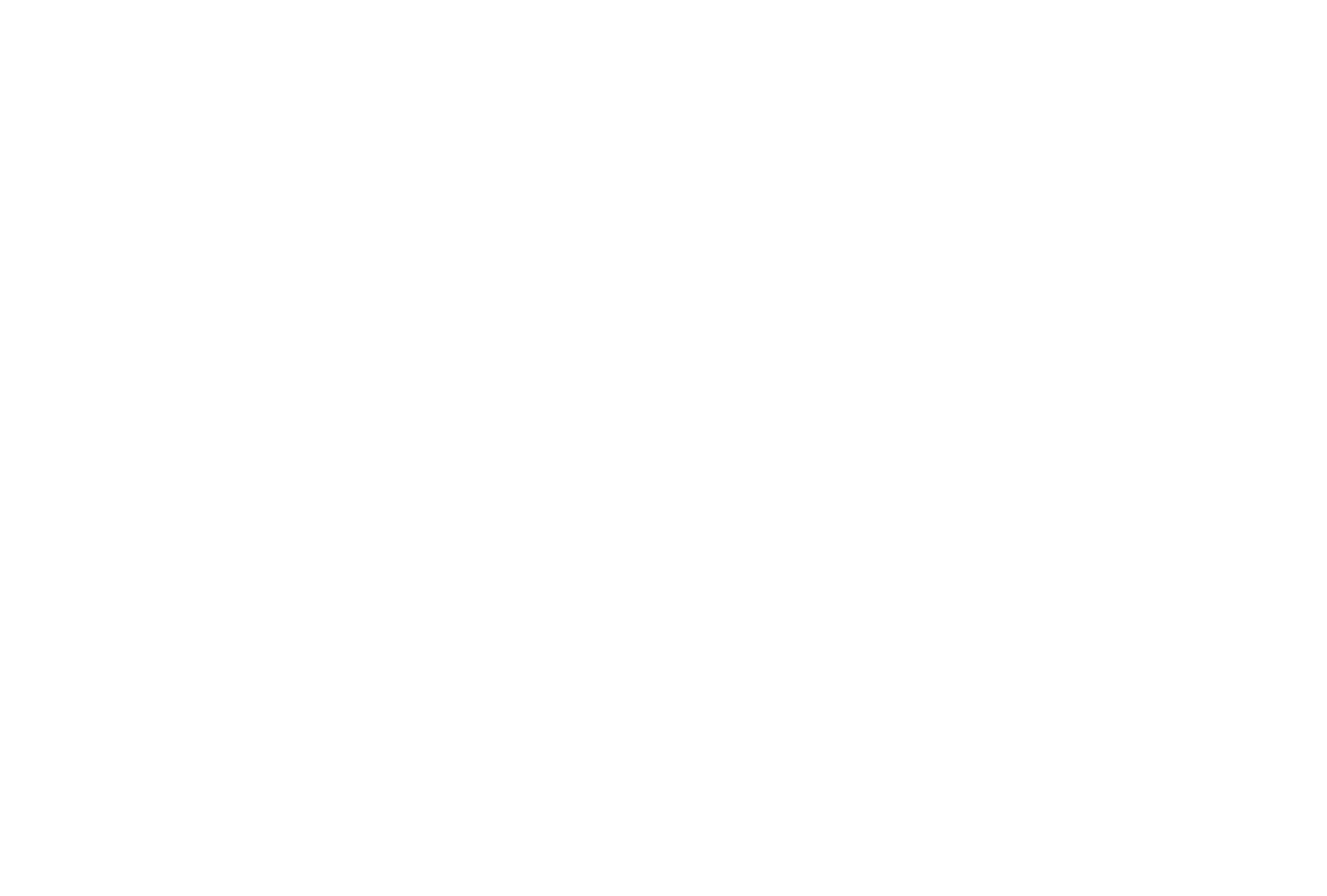

Figure S49. ${ }^{1} \mathrm{H}$ NMR of compound $\mathbf{1 2 b}$ in $\mathrm{CDCl}_{3}$ at $500 \mathrm{MHz}$ 
${ }^{1} \mathrm{H}$ and ${ }^{13} \mathrm{C}$ NMR spectrum of compounds $16 \mathrm{a}$ and $16 \mathrm{~b}$

SpinWorks 4: PROTON CDCl3 E: \data CUG

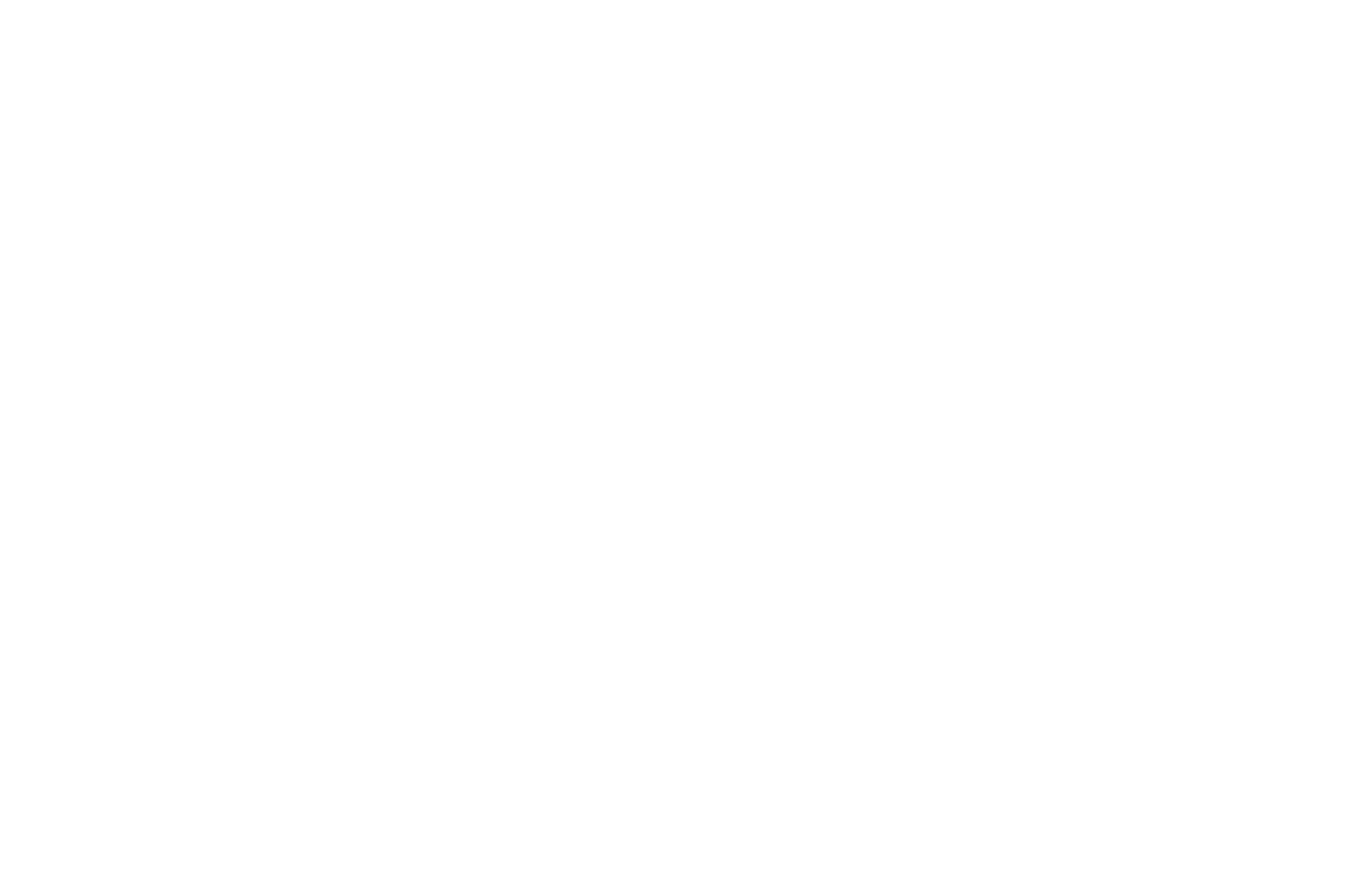

Figure S50. ${ }^{1} \mathrm{H}$ NMR of compound 16a in $\mathrm{CDCl}_{3}$ at $500 \mathrm{MHz}$ 


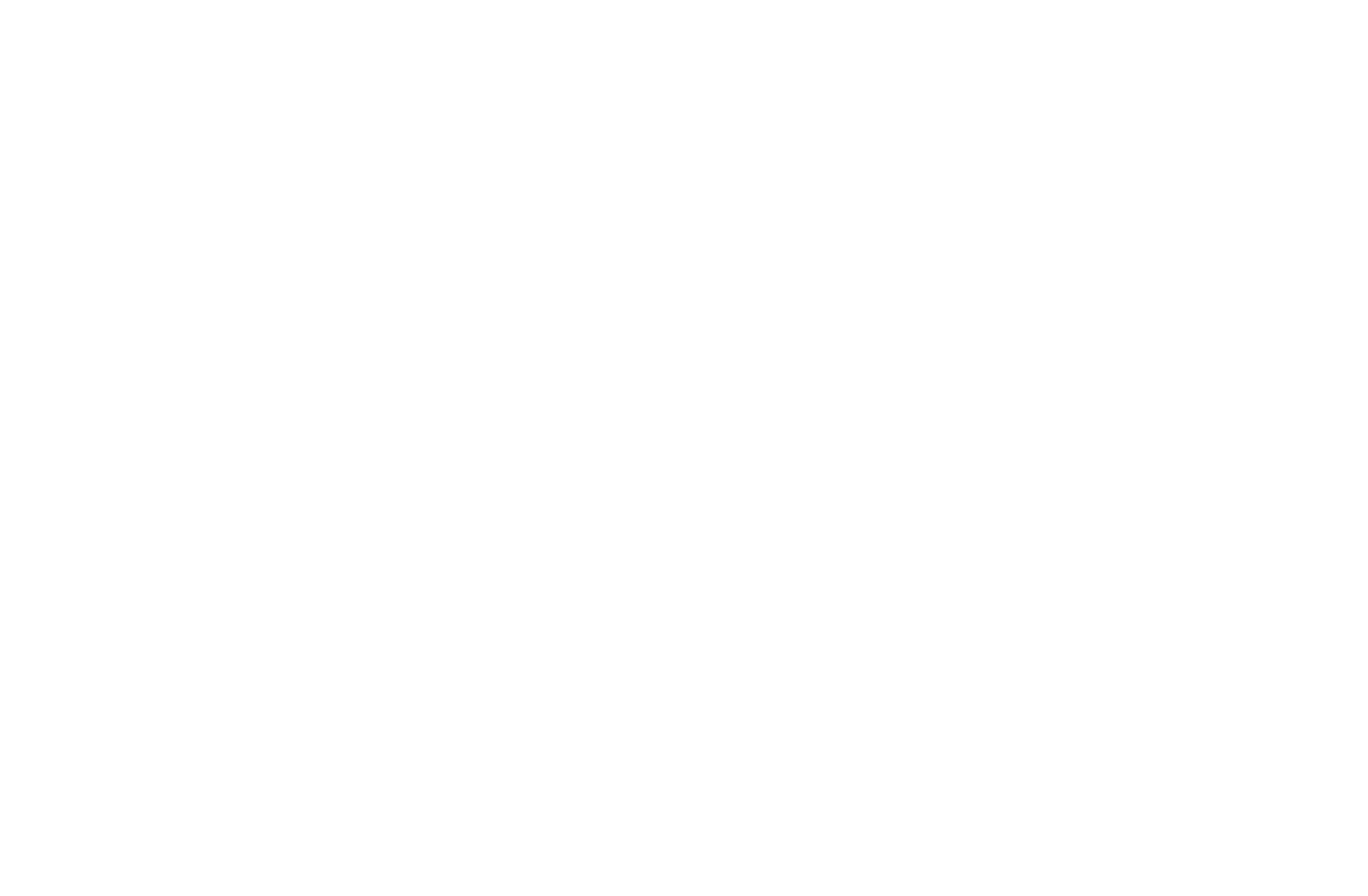

Figure S51. ${ }^{13} \mathrm{C}$ NMR of compound 16a in $\mathrm{CD}_{3} \mathrm{OD}$ at $500 \mathrm{MHz}$ 


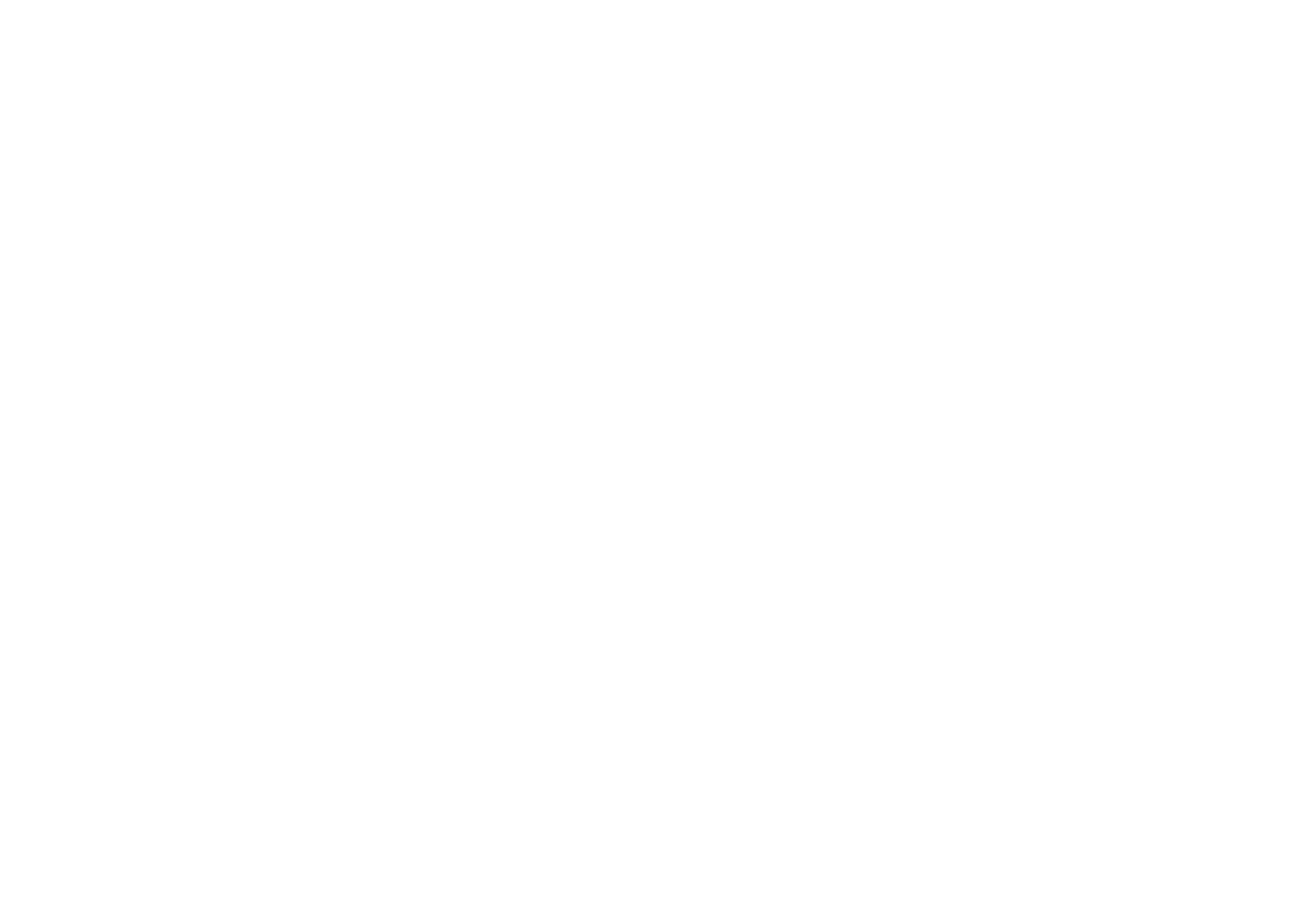

Figure S52. ${ }^{1} \mathrm{H}$ NMR of compound $\mathbf{1 6 b}$ in $\mathrm{CDCl}_{3}$ at $500 \mathrm{MHz}$ 


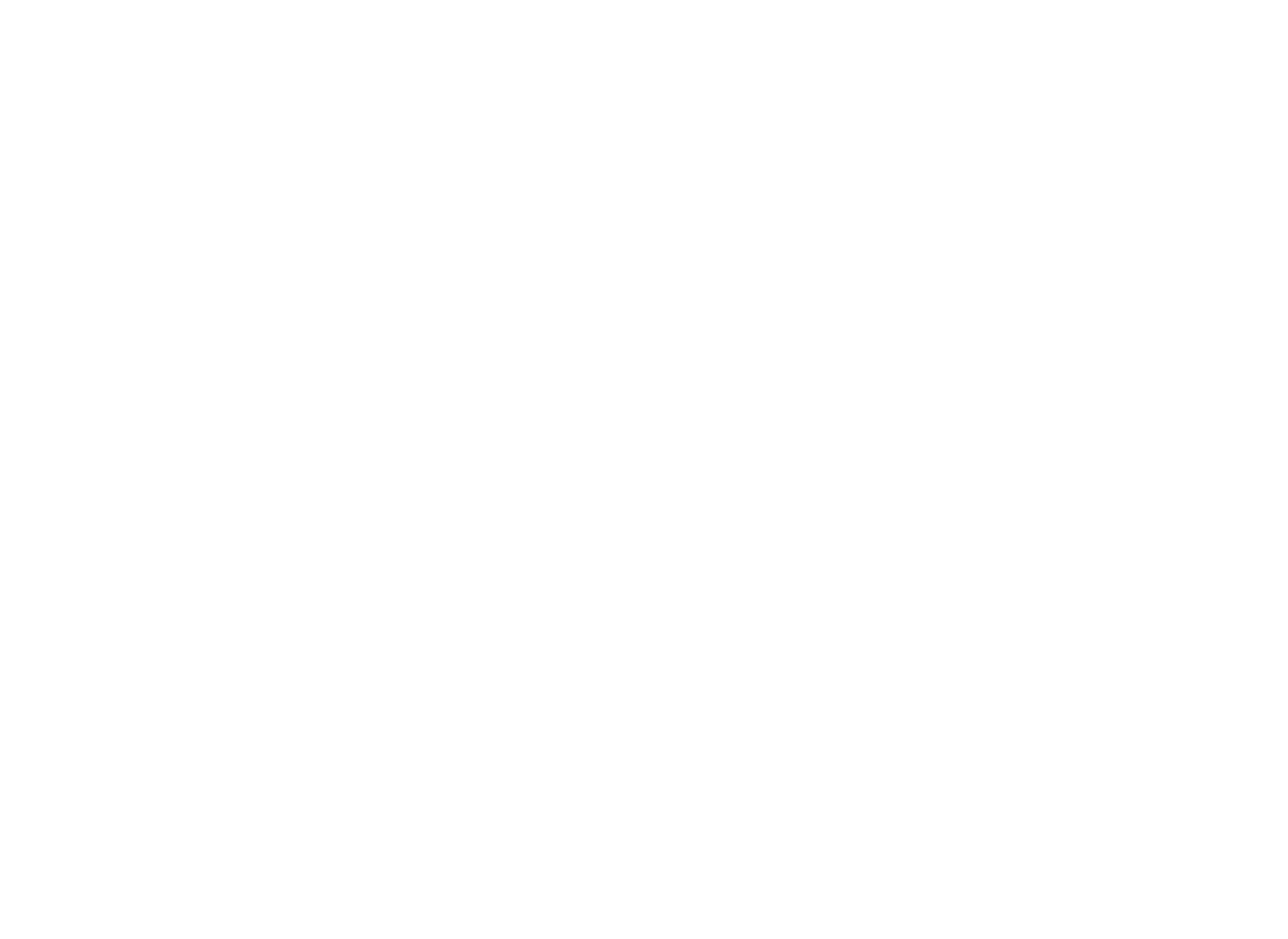

Figure S53. ${ }^{13} \mathrm{C}$ NMR of compound $\mathbf{1 6 b}$ in $\mathrm{CDCl}_{3}$ at $500 \mathrm{MHz}$ 


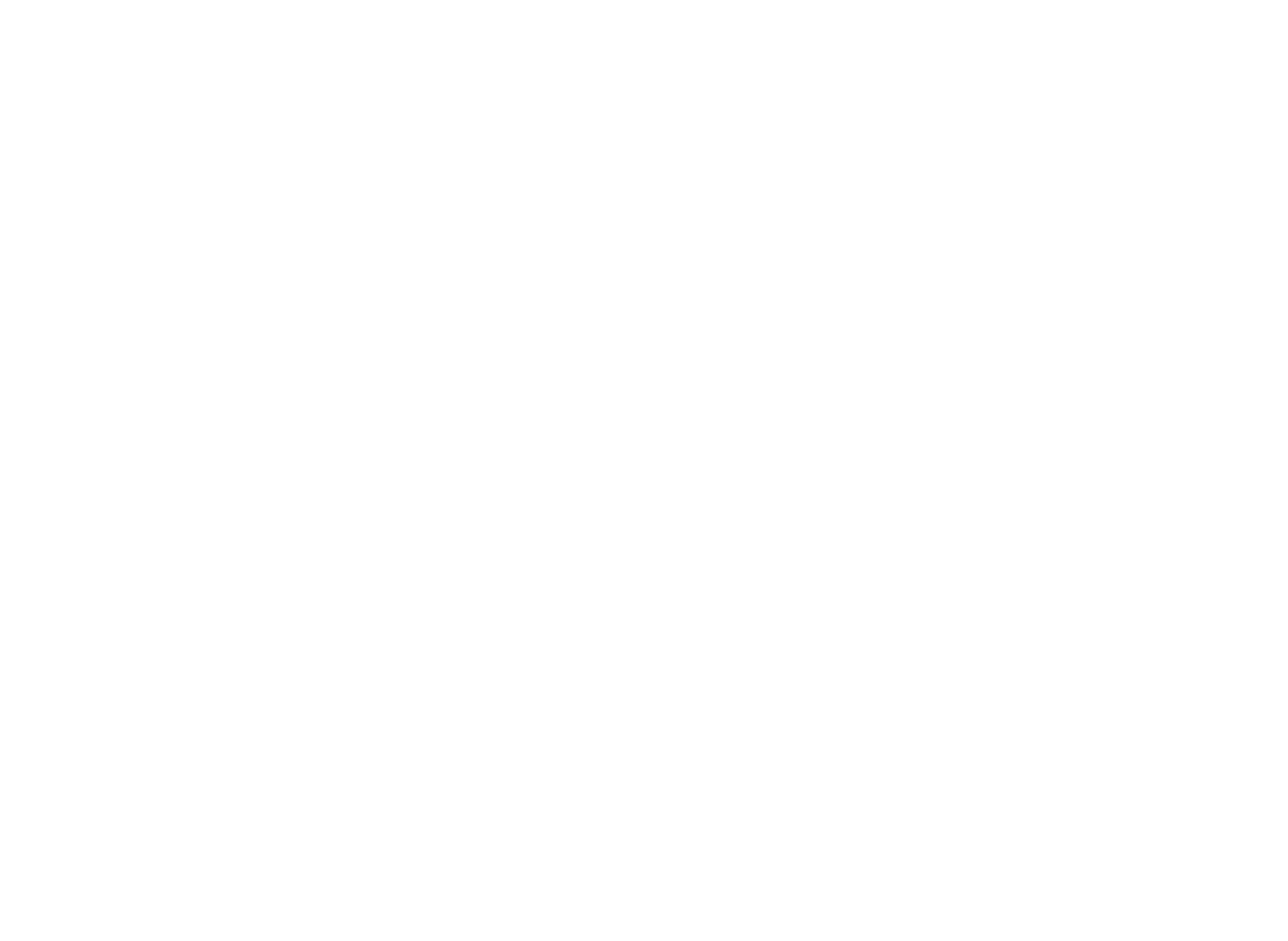

Figure S54. ${ }^{1} \mathrm{H}$ NMR of SDS in $\mathrm{D}_{2} \mathrm{O}$ at $500 \mathrm{MHz}$ 
$\underline{{ }^{1} \mathrm{H} \text { and }{ }^{13} \mathrm{C} \text { NMR spectrum of compounds (1a-1j) }}$

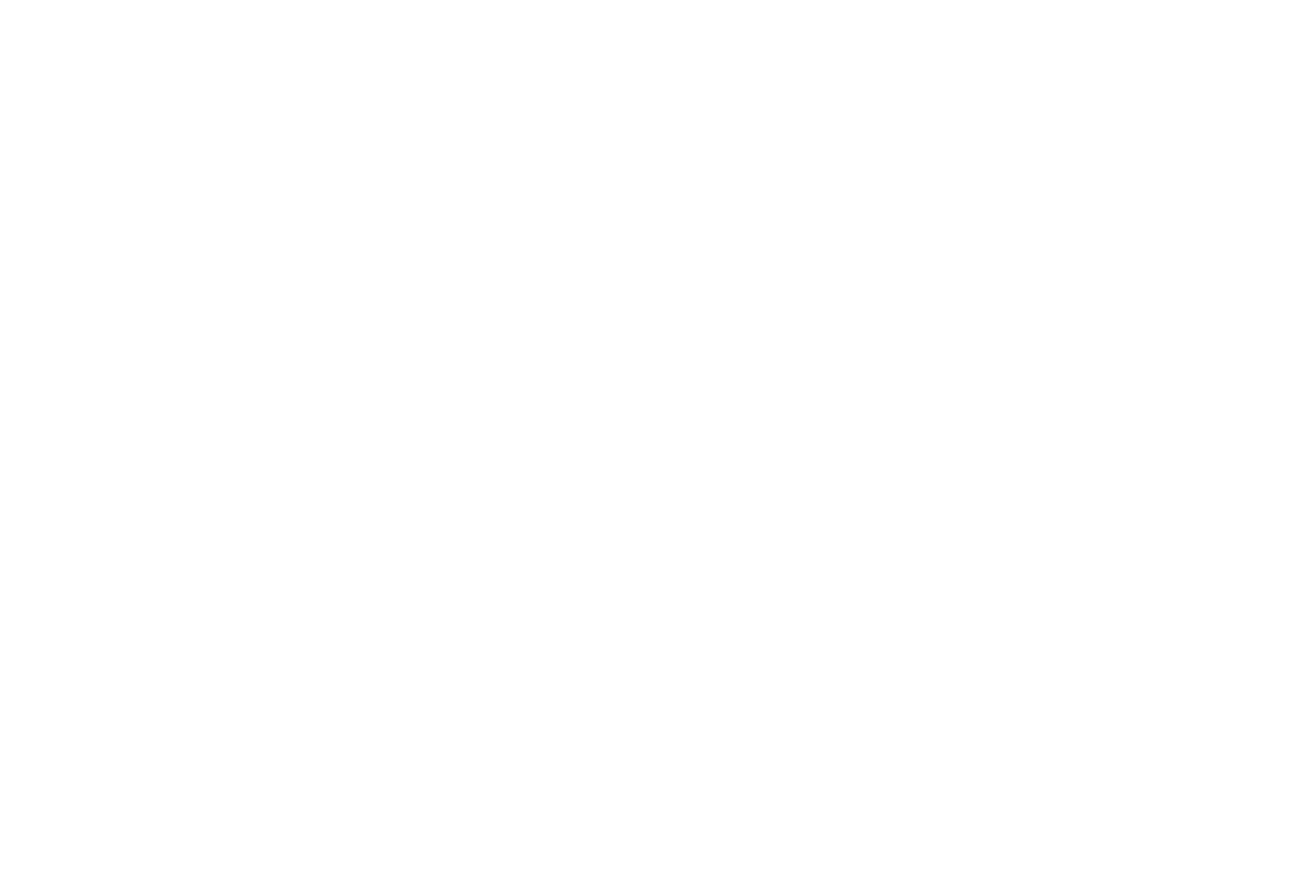

Figure S55. ${ }^{1} \mathrm{H}$ NMR of compound $1 \mathrm{a}$ in $\mathrm{CDCl}_{3}$ at $500 \mathrm{MHz}$ 


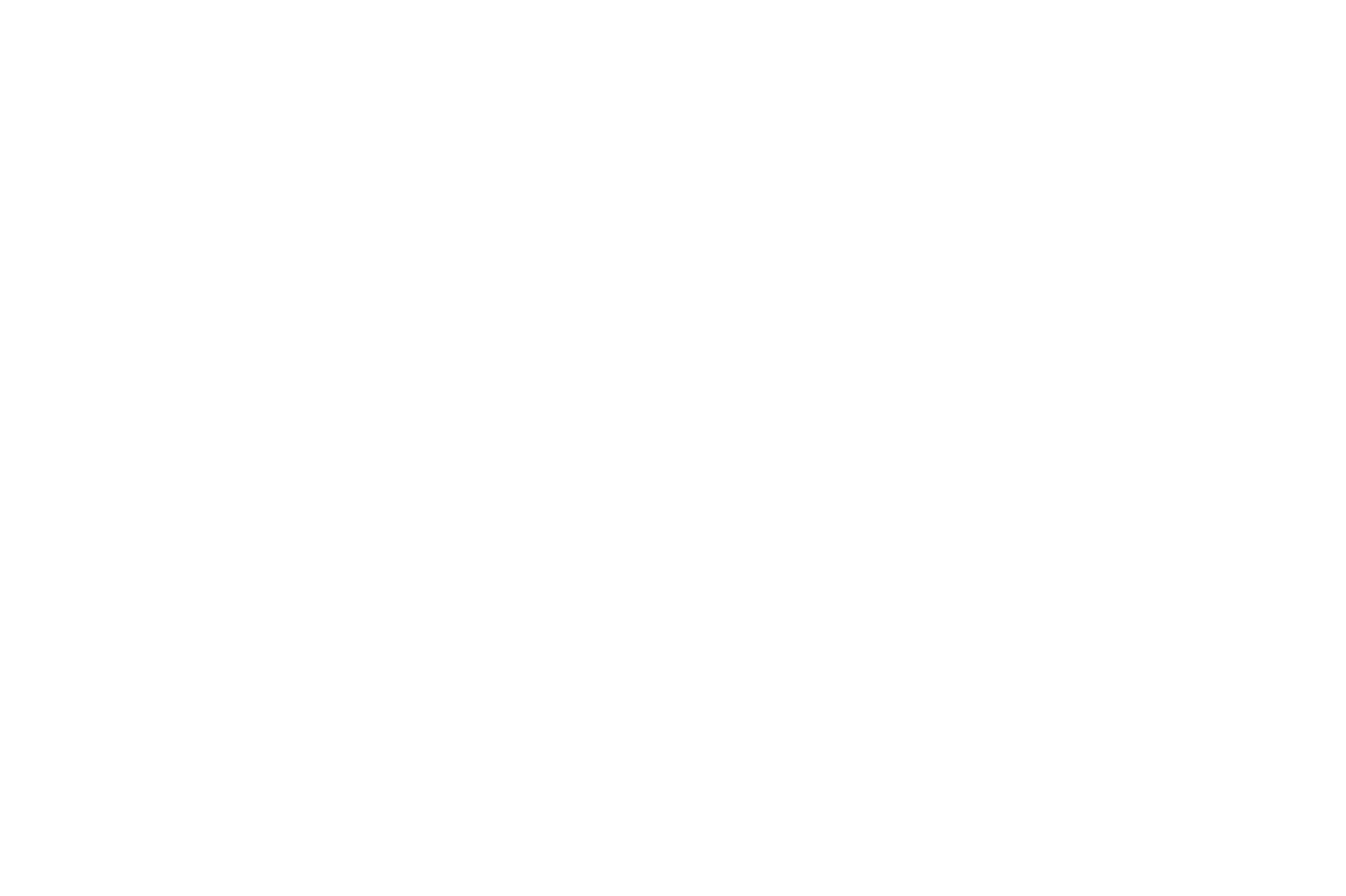

Figure S56. ${ }^{13} \mathrm{C}$ NMR of compound $\mathbf{1 a}$ in $\mathrm{CDCl}_{3}$ at $500 \mathrm{MHz}$ 


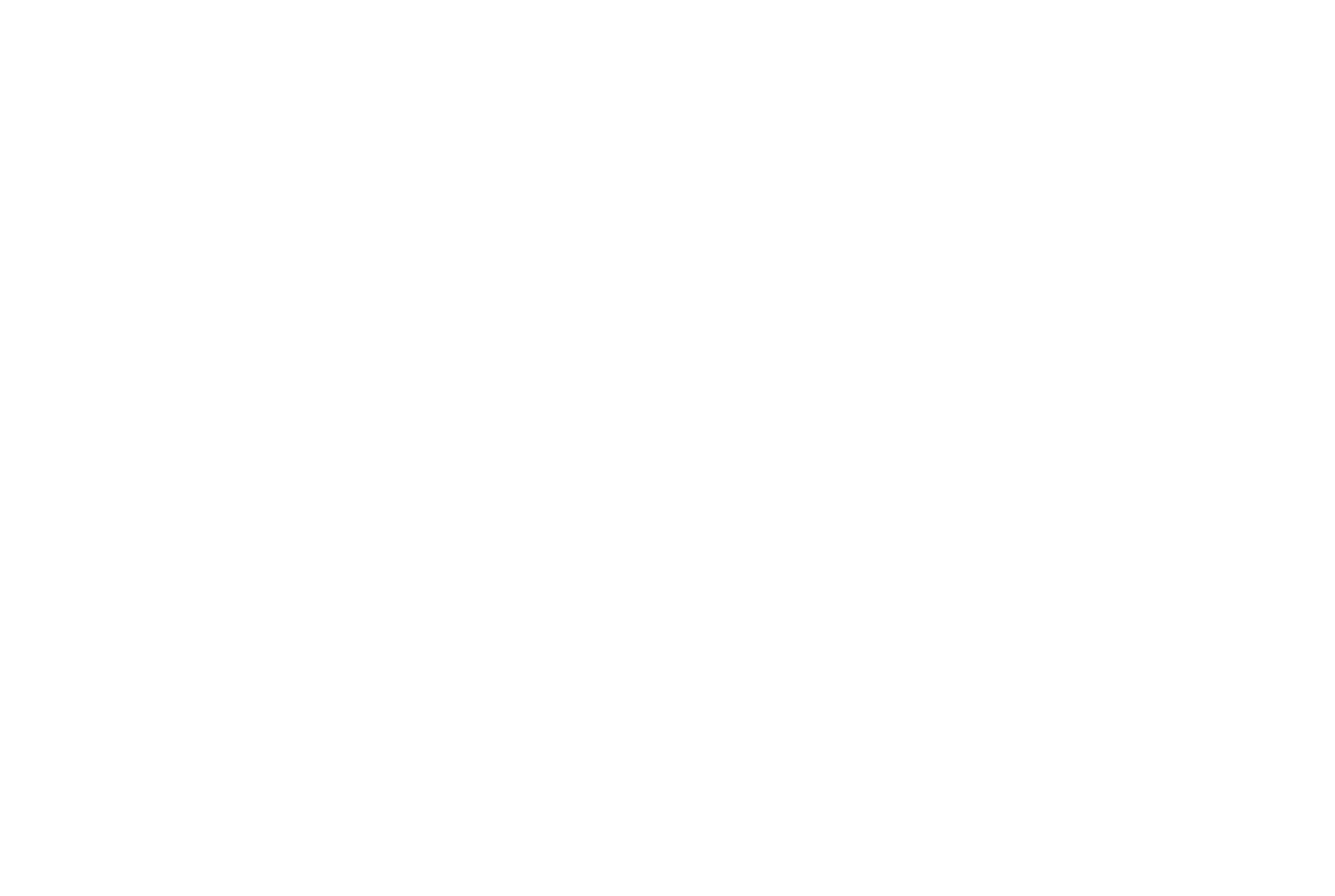

Figure S57. ${ }^{1} \mathrm{H}$ NMR of compound $\mathbf{1 b}$ in $\mathrm{CDCl}_{3}$ at $500 \mathrm{MHz}$ 


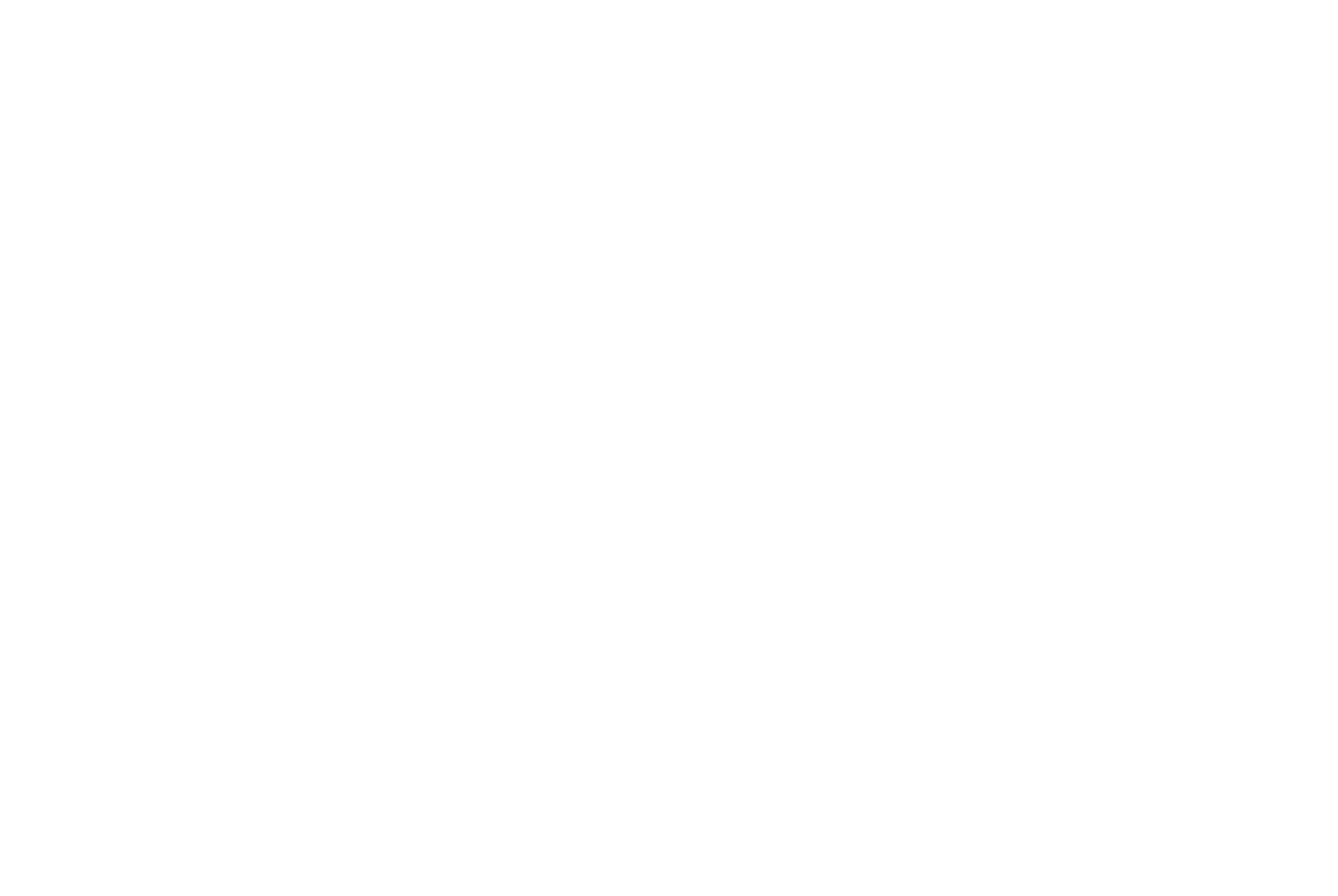

Figure 58. ${ }^{13} \mathrm{C}$ NMR of compound $\mathbf{1 b}$ in $\mathrm{CDCl}_{3}$ at $500 \mathrm{MHz}$ 
SpinWorks 4: PROTON CDCl3 E: \data CUG

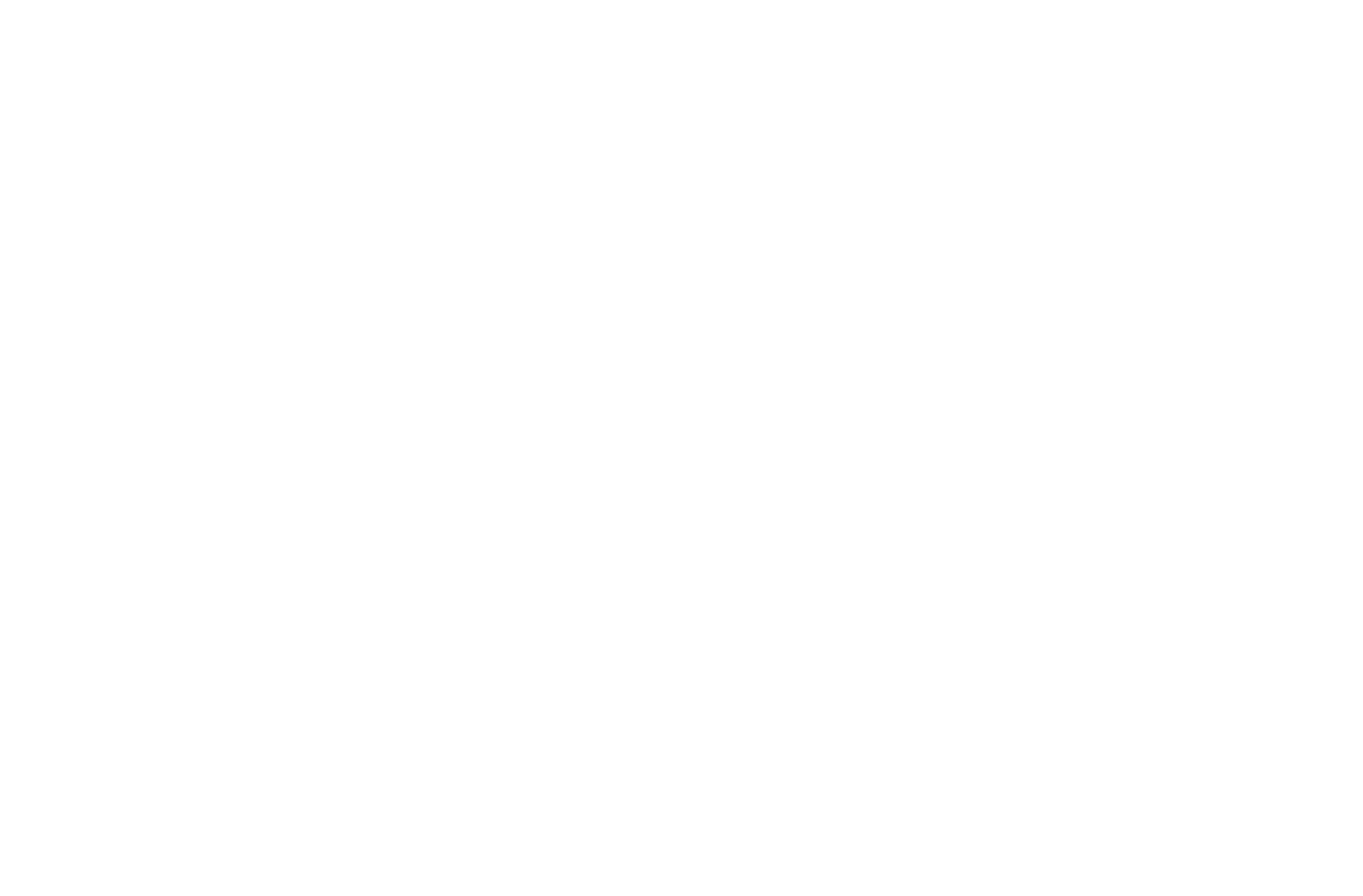

Figure 59. ${ }^{1} \mathrm{H}$ NMR of compound $1 \mathrm{c}$ in $\mathrm{CDCl}_{3}$ at $500 \mathrm{MHz}$ 


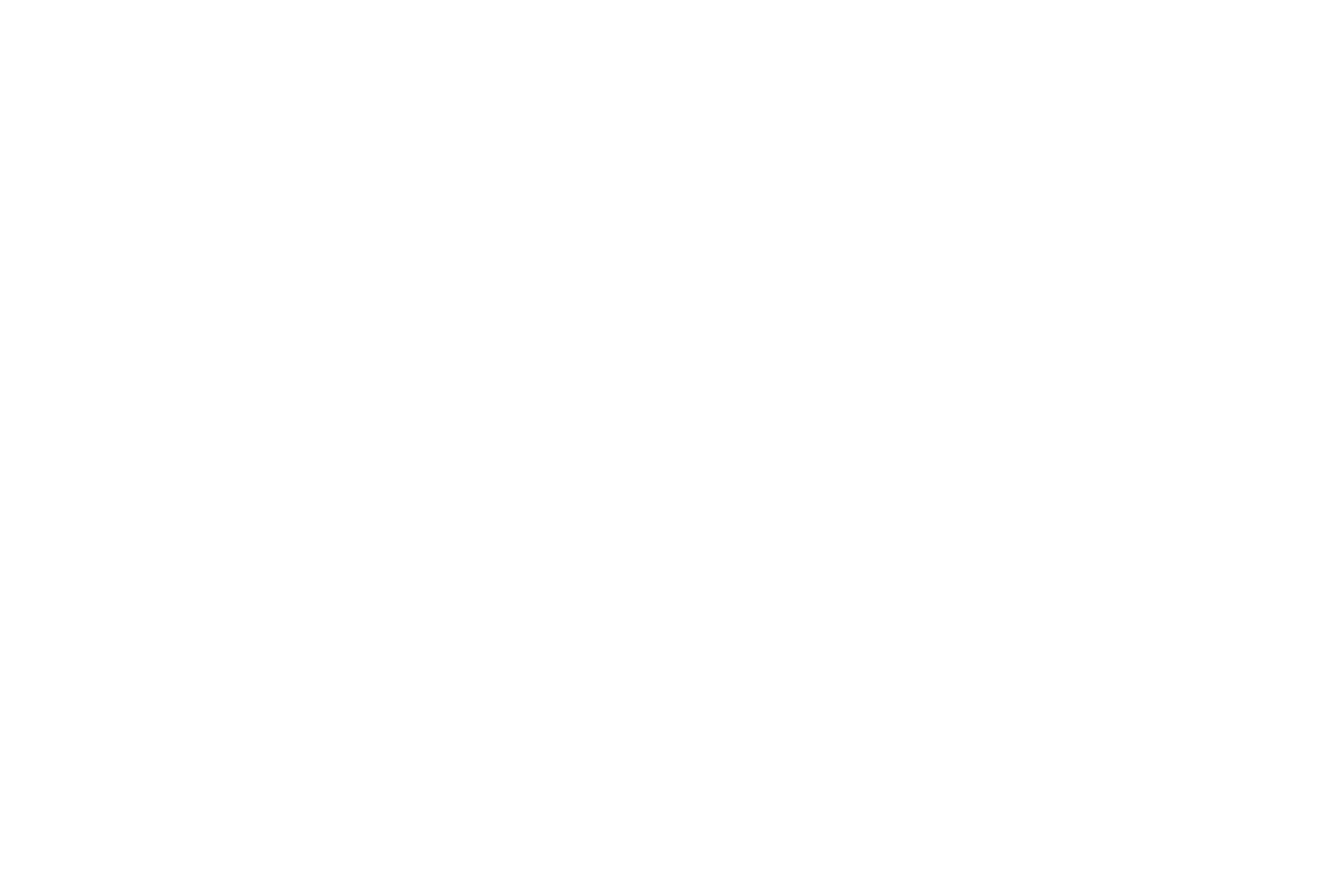

Figure 60. ${ }^{13} \mathrm{C}$ NMR of compound $1 \mathrm{c}$ in $\mathrm{CDCl}_{3}$ at $500 \mathrm{MHz}$ 


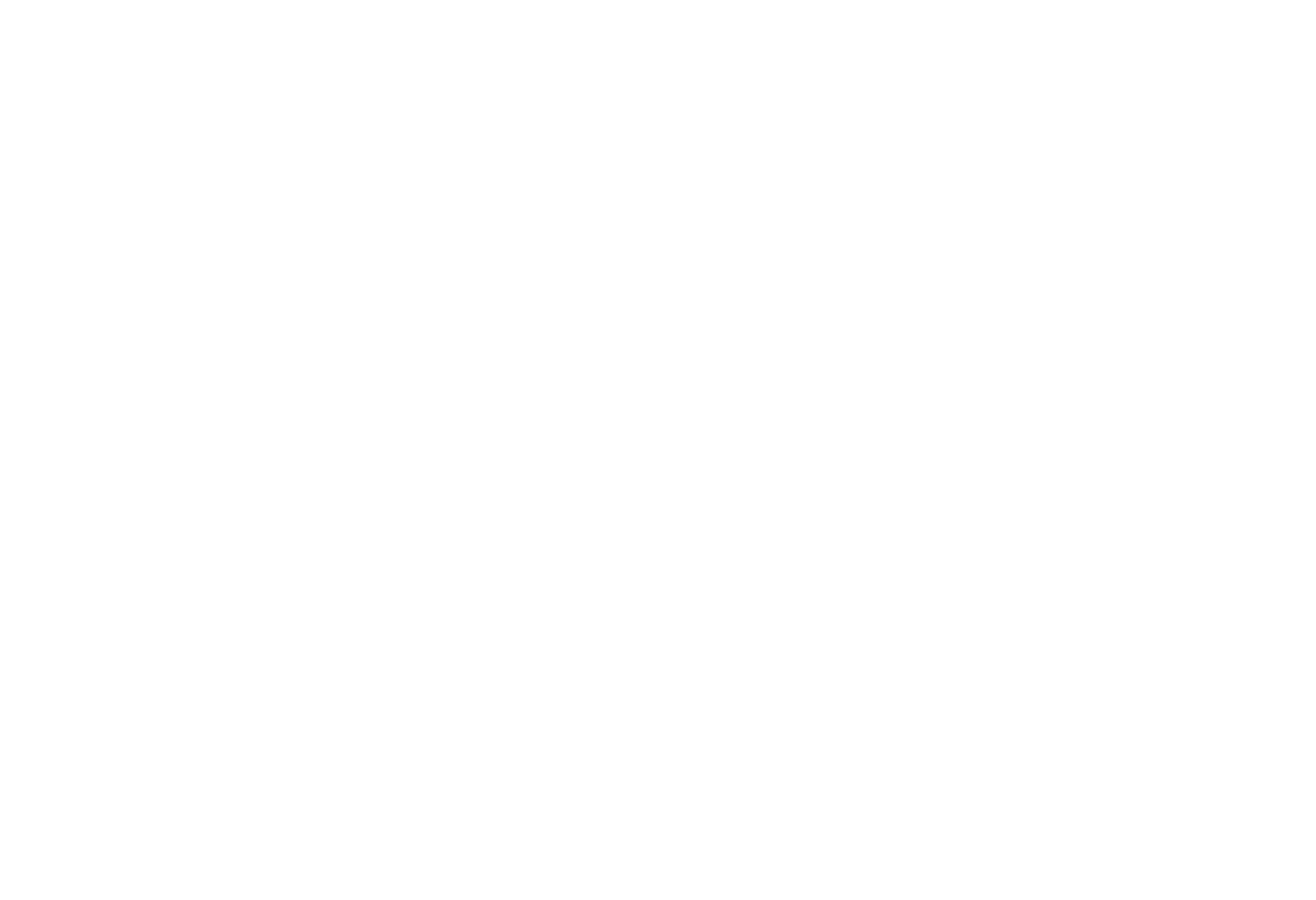

Figure S61. ${ }^{1} \mathrm{H}$ NMR of compound $\mathbf{1 d}$ in $\mathrm{CDCl}_{3}$ at $500 \mathrm{MHz}$ 


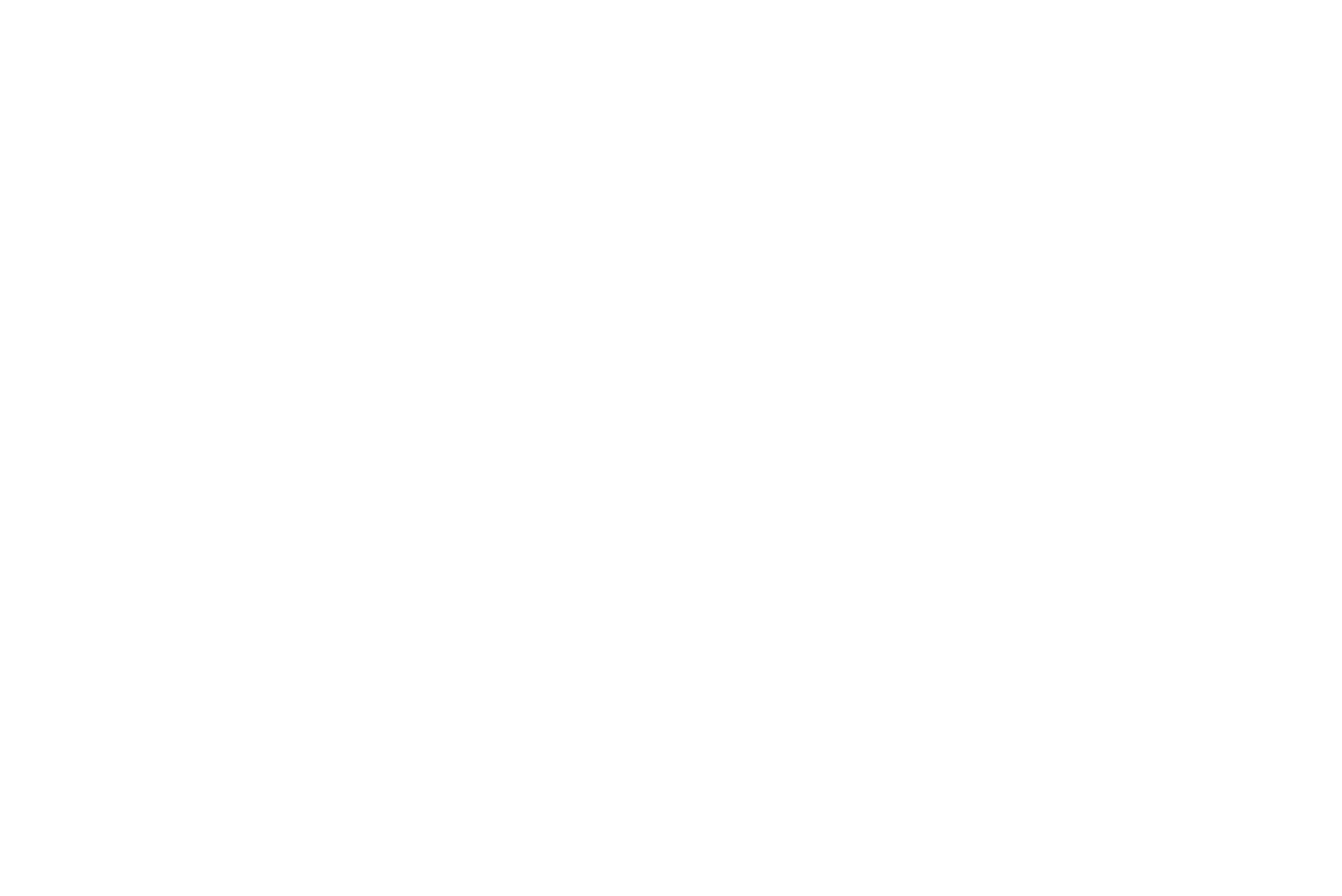

Figure S62. ${ }^{13} \mathrm{C} \mathrm{NMR}$ of compound $\mathbf{1 d}$ in $\mathrm{CDCl}_{3}$ at $500 \mathrm{MHz}$ 
SpinWorks 4: PROTON CDCl3 E: \data CUG

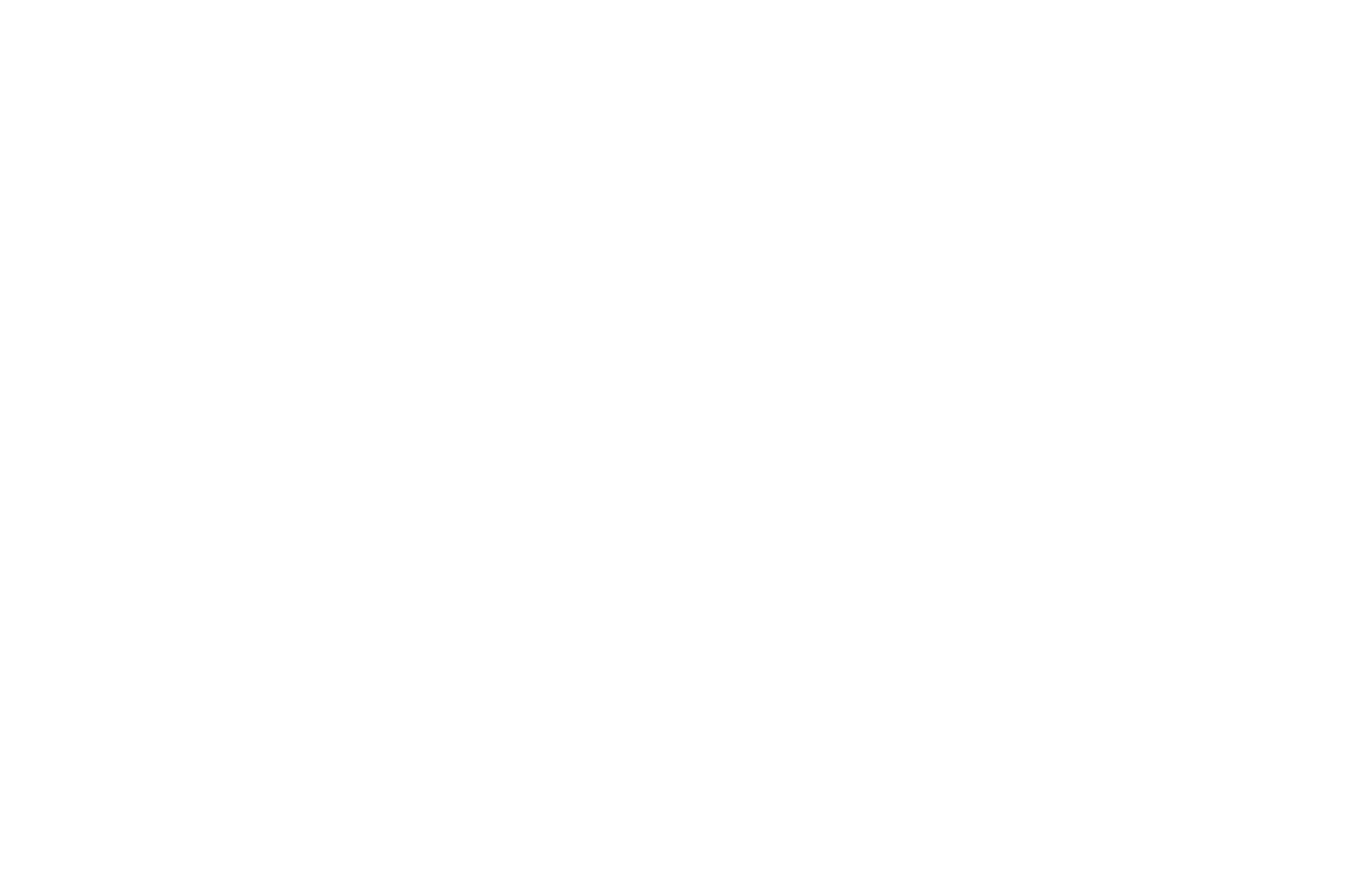

Figure S63. ${ }^{1} \mathrm{H}$ NMR of compound $1 \mathrm{e}$ in $\mathrm{CDCl}_{3}$ at $500 \mathrm{MHz}$ 
SpinWorks 4: GCMB-C13

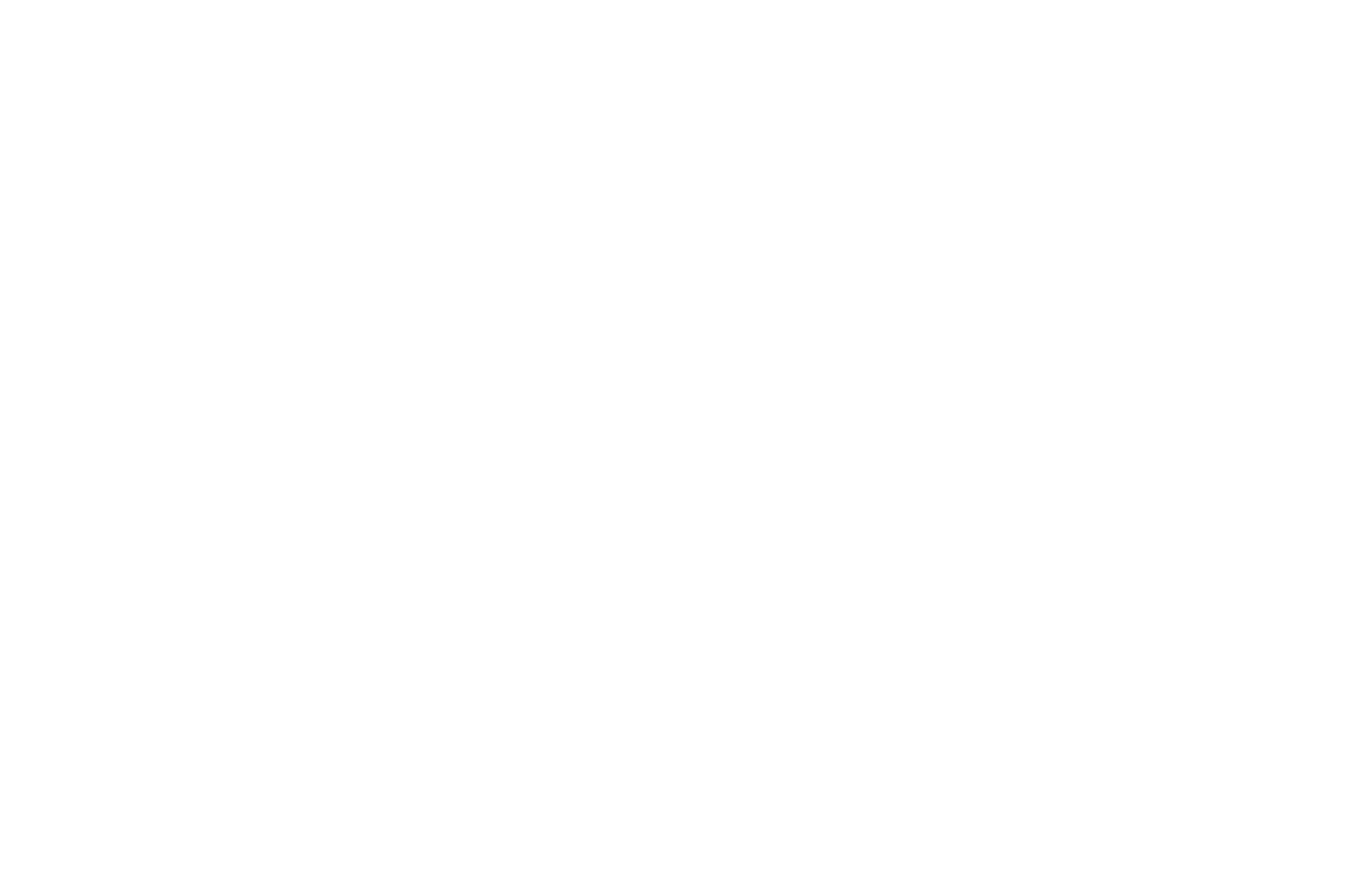

Figure S64. ${ }^{13} \mathrm{C}$ NMR of compound $1 e$ in $\mathrm{CDCl}_{3}$ at $500 \mathrm{MHz}$ 


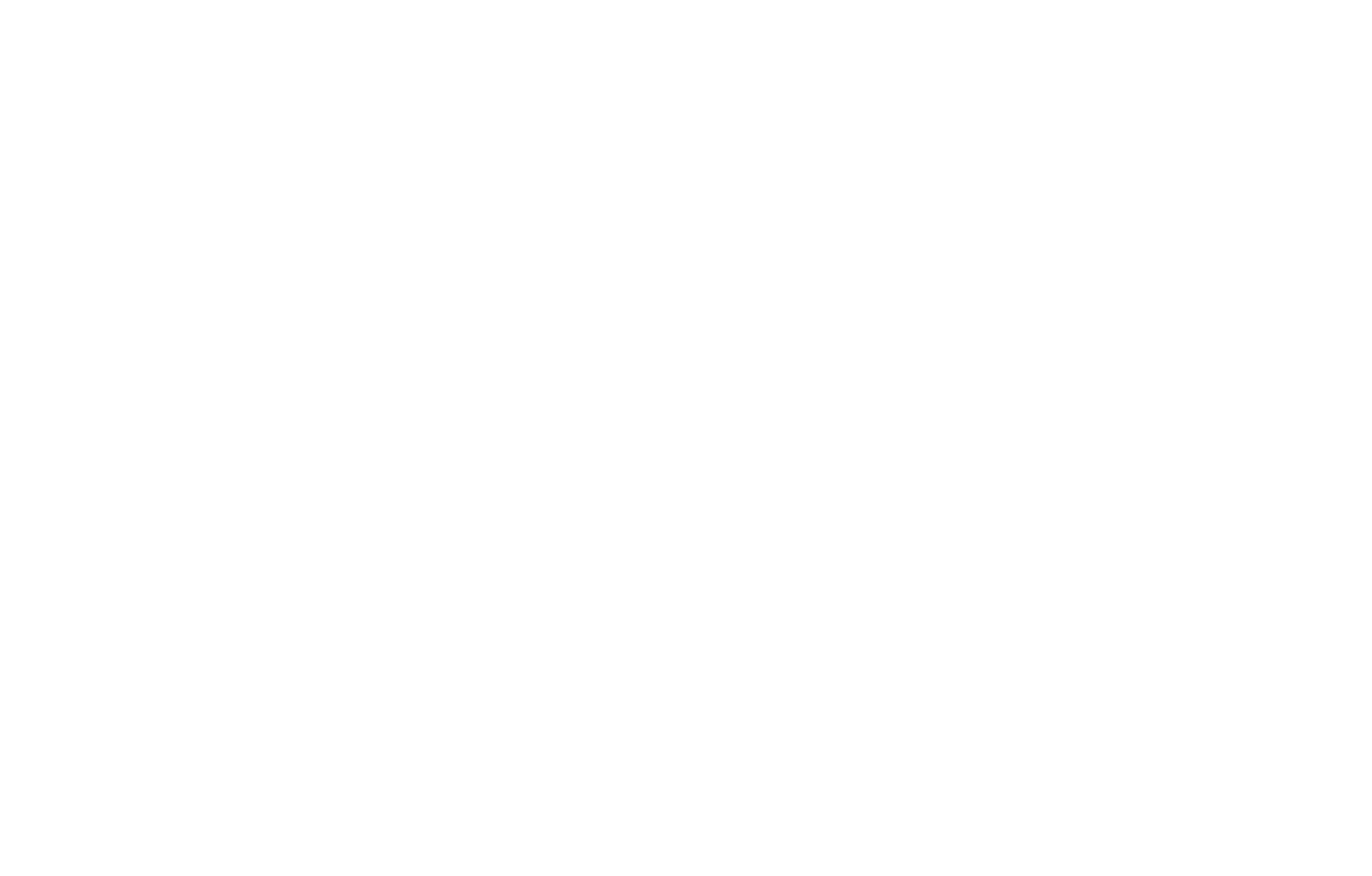

Figure S65. ${ }^{1} \mathrm{H}$ NMR of compound $1 f$ in $\mathrm{CDCl}_{3}$ at $500 \mathrm{MHz}$ 


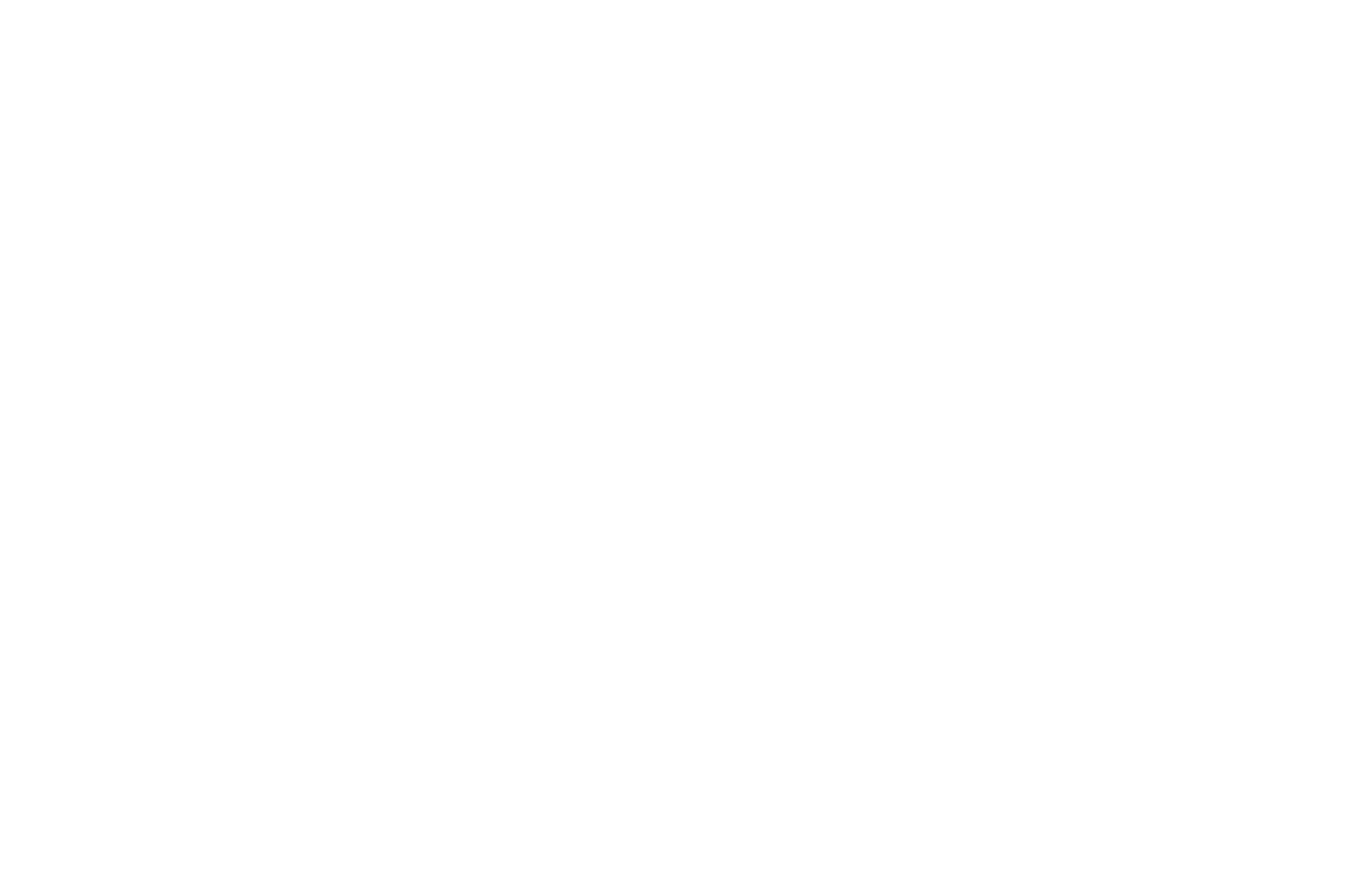

Figure S66. ${ }^{13} \mathrm{C} \mathrm{NMR}$ of compound $1 \mathrm{f}$ in $\mathrm{CDCl}_{3}$ at $500 \mathrm{MHz}$ 
SpinWorks 4: PROTON CDCl3 E:\data CUG

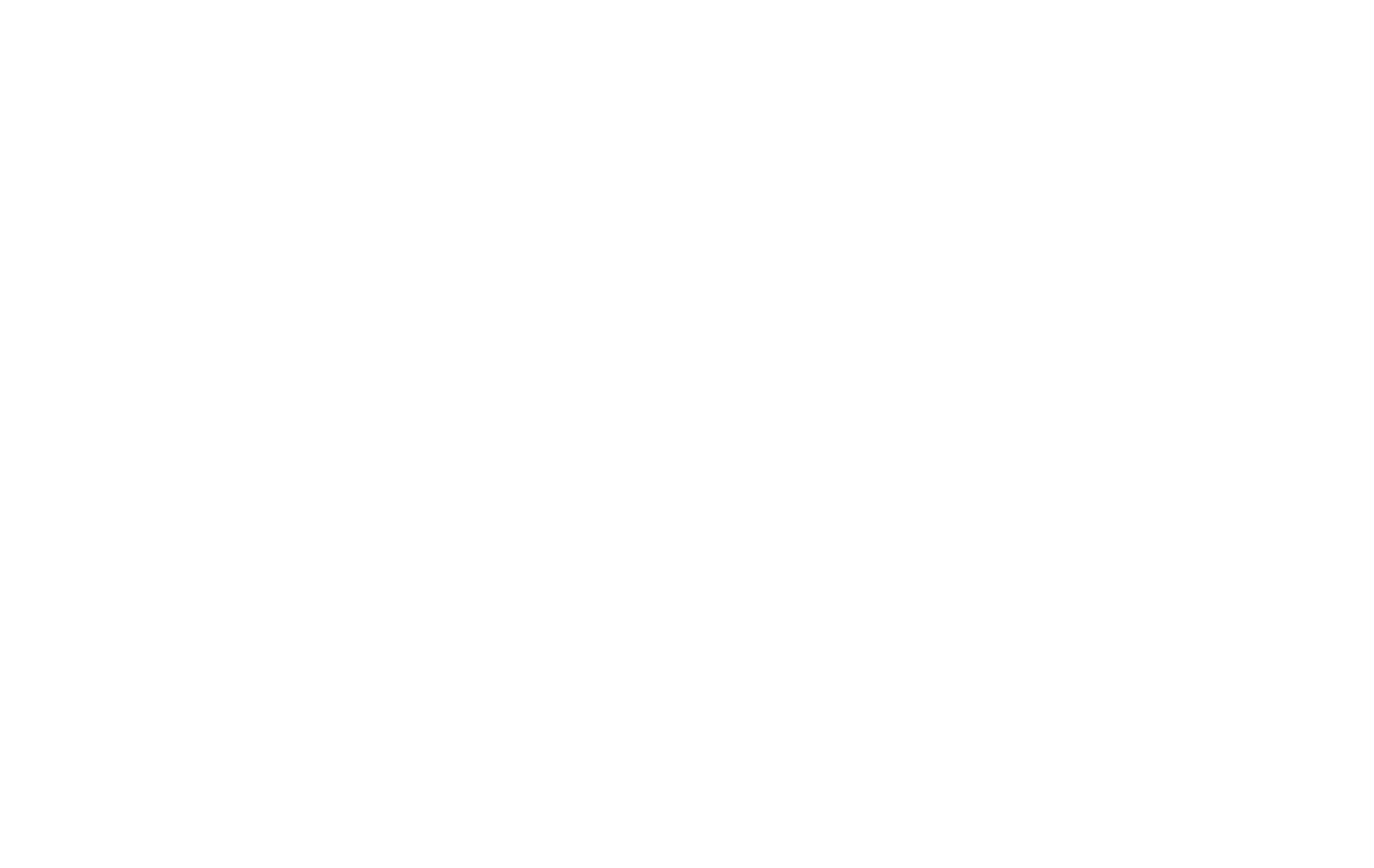

Figure S67. ${ }^{1} \mathrm{H}$ NMR of compound $1 \mathrm{~g}$ in $\mathrm{CDCl}_{3}$ at $500 \mathrm{MHz}$ 


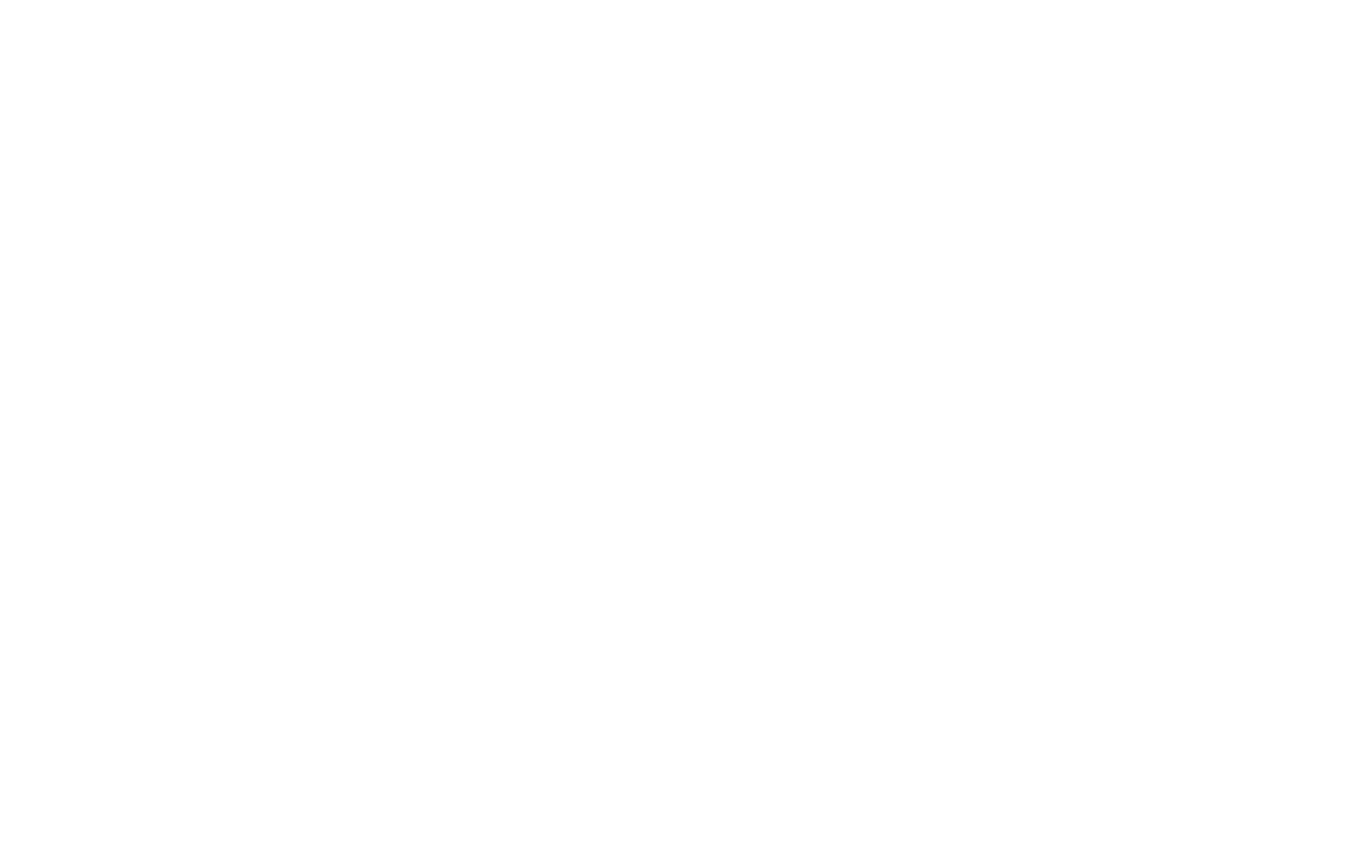

Figure S68. ${ }^{13} \mathrm{C} \mathrm{NMR}$ of compound $1 \mathrm{~g}$ in $\mathrm{CDCl}_{3}$ at $500 \mathrm{MHz}$ 


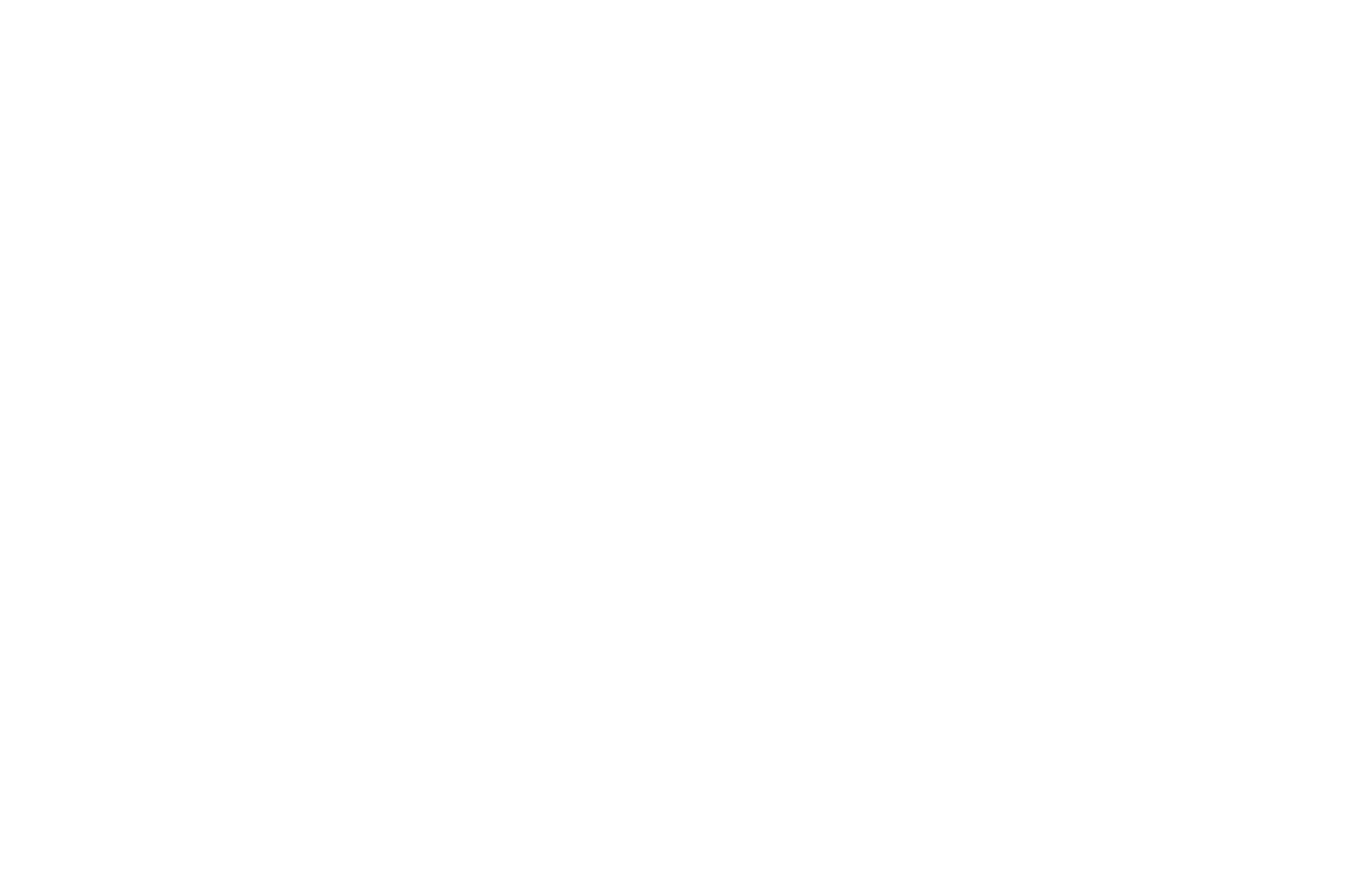

Figure S69. ${ }^{1} \mathrm{H}$ NMR of compound $1 \mathbf{h}$ in $\mathrm{CDCl}_{3}$ at $500 \mathrm{MHz}$ 
Spin Works 4: GAL

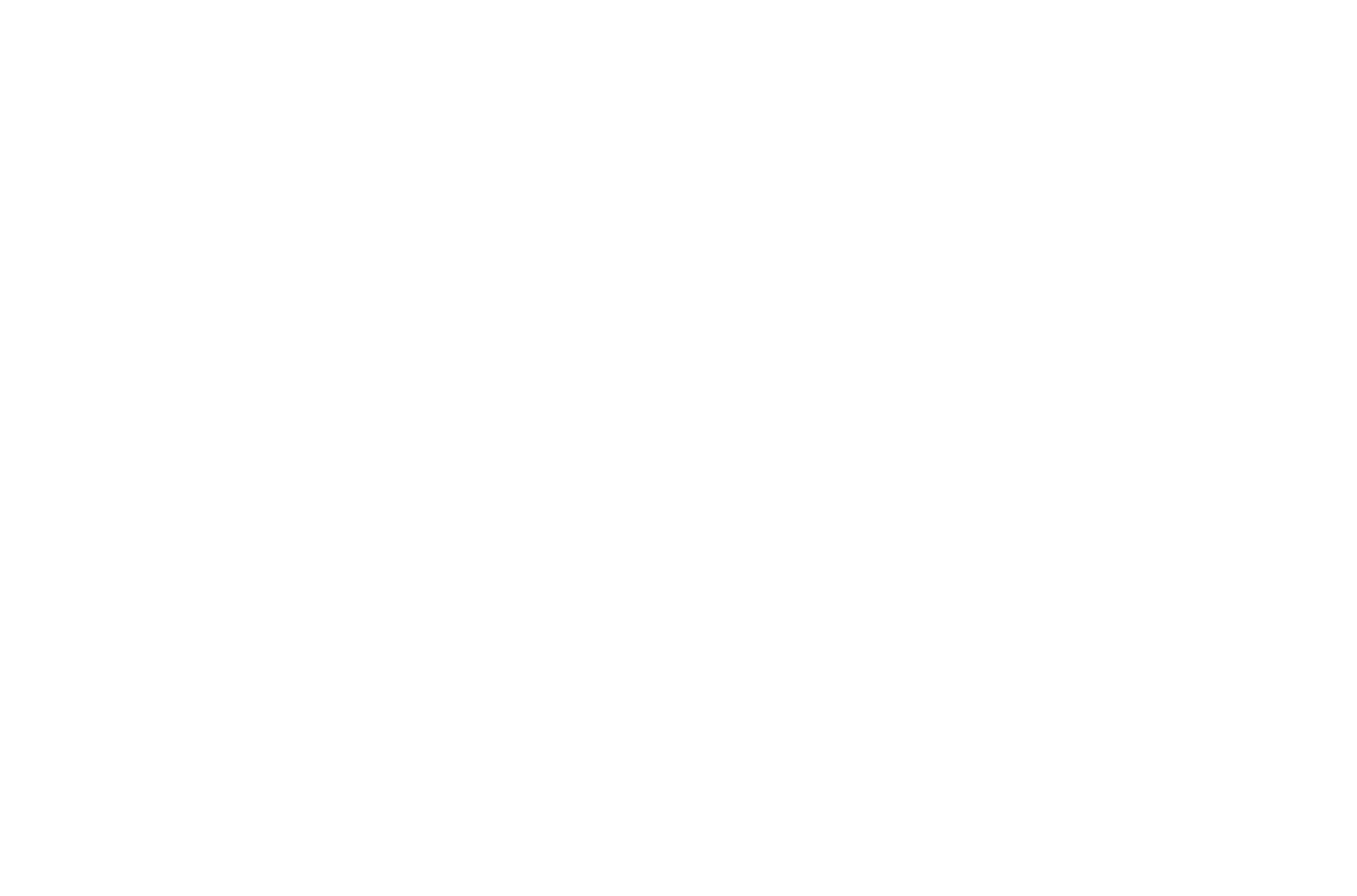

Figure S70. ${ }^{13} \mathrm{C}$ NMR of compound $\mathbf{1 h}$ in $\mathrm{CDCl}_{3}$ at $500 \mathrm{MHz}$ 


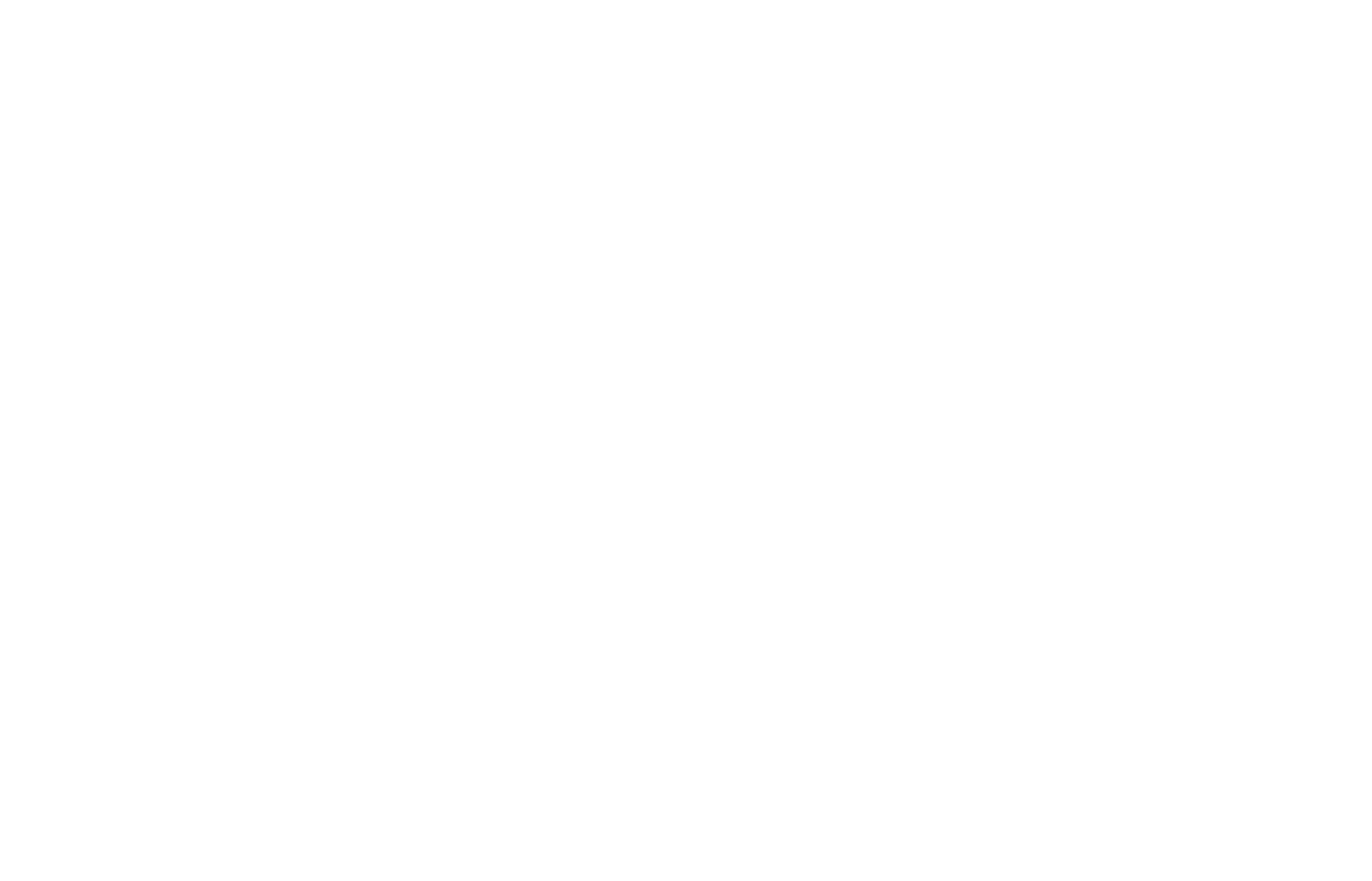

Figure S71. ${ }^{1} \mathrm{H}$ NMR of compound $1 \mathrm{i}$ in $\mathrm{CDCl}_{3}$ at $500 \mathrm{MHz}$ 


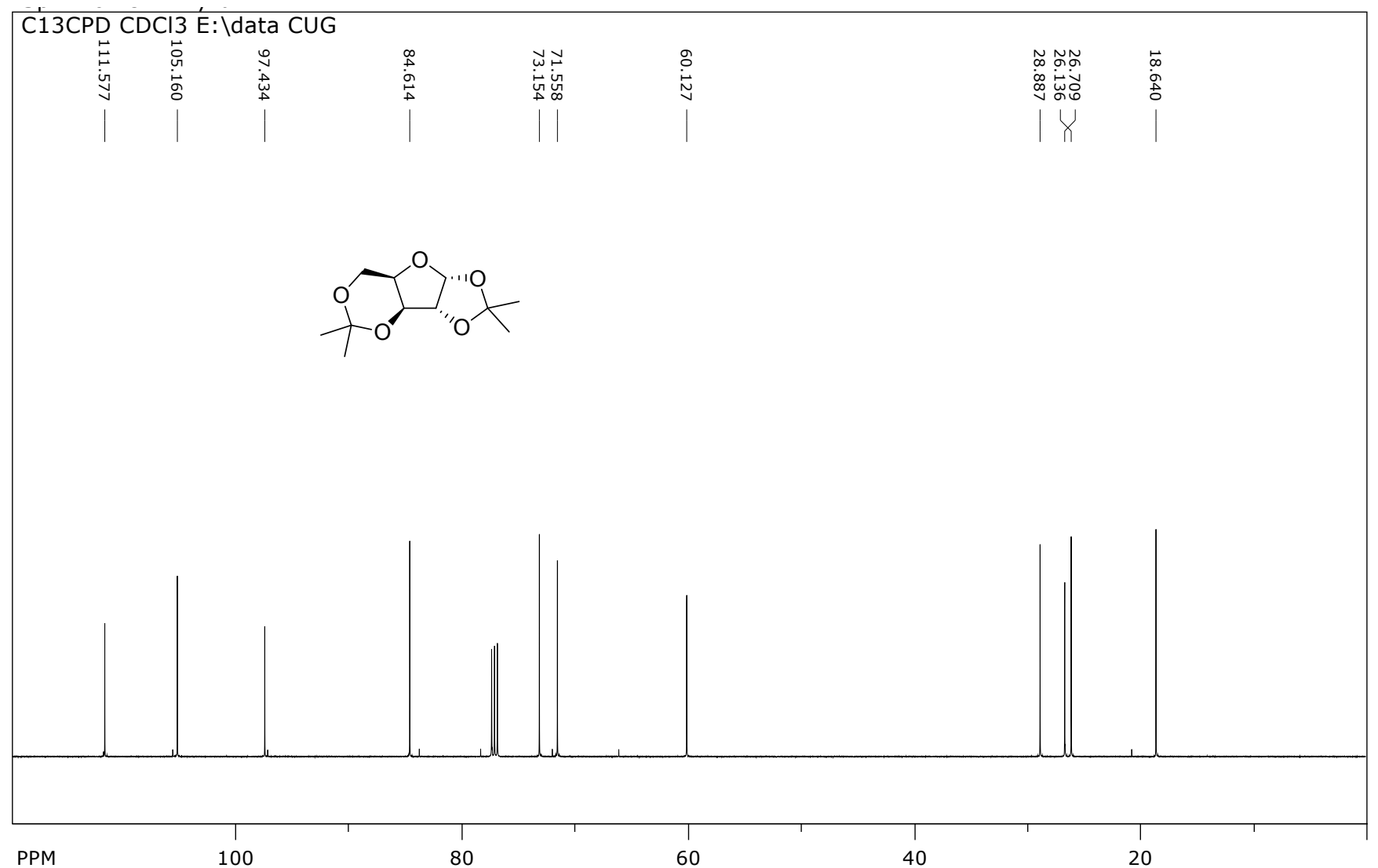

Figure S72. ${ }^{13} \mathrm{C}$ NMR of compound $1 \mathrm{i}$ in $\mathrm{CDCl}_{3}$ at $500 \mathrm{MHz}$ 


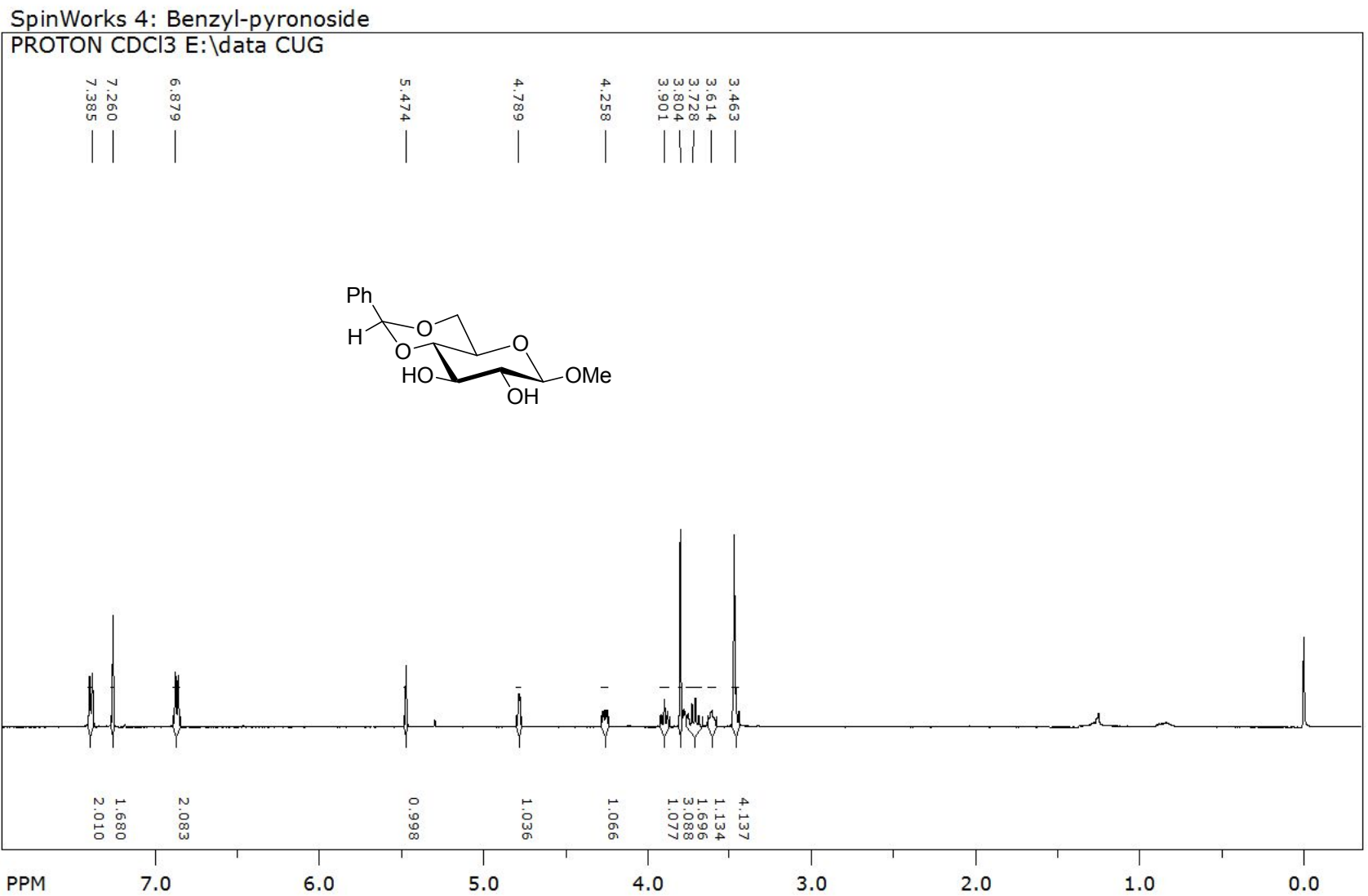

Figure S73. ${ }^{1} \mathrm{H}$ NMR of compound $\mathbf{1 j}$ in $\mathrm{CDCl}_{3}$ at $500 \mathrm{MHz}$ 


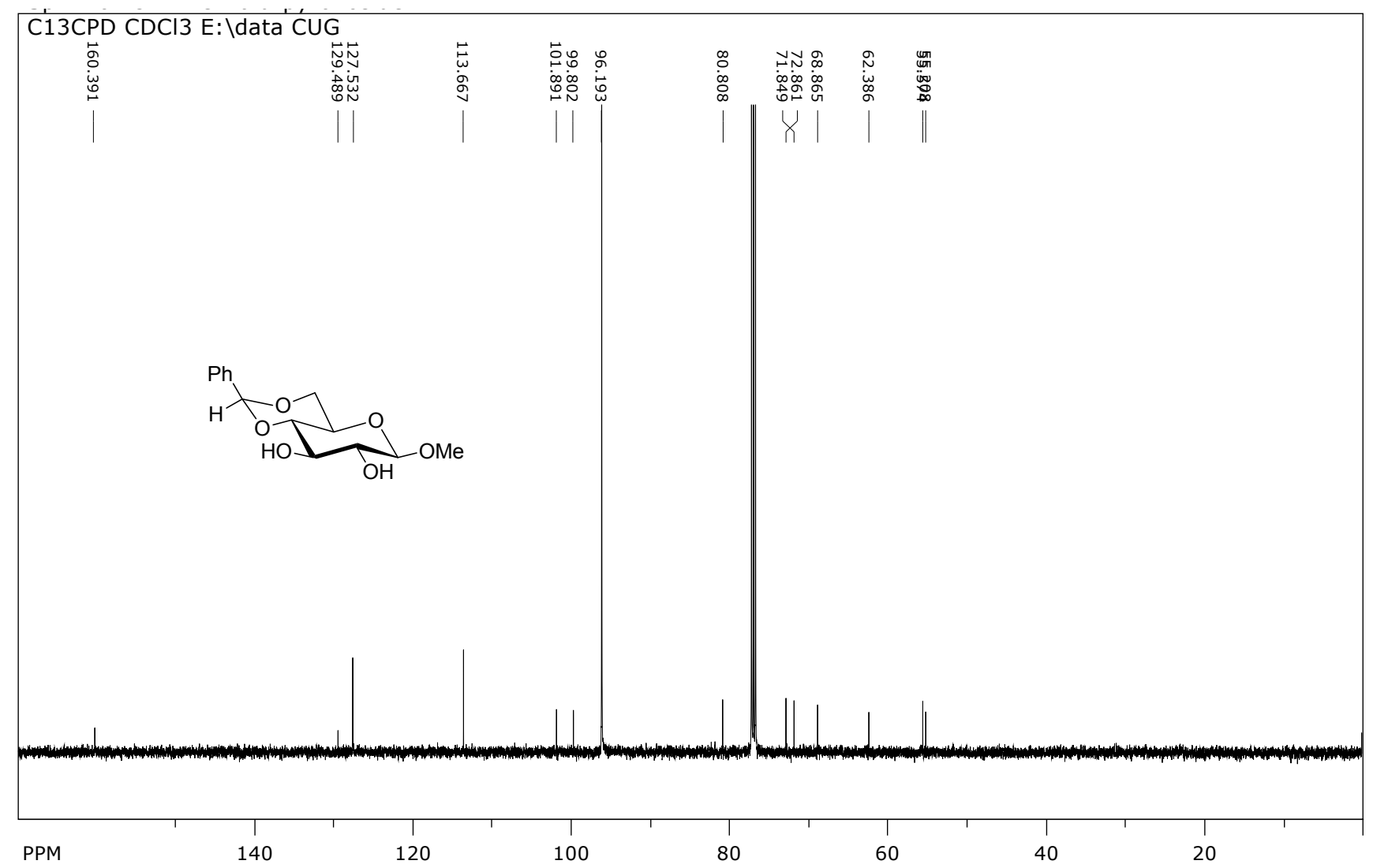

Figure $\mathbf{S 7 4} .{ }^{13} \mathrm{C}$ NMR of compound $\mathbf{1 j}$ in $\mathrm{CDCl}_{3}$ at $500 \mathrm{MHz}$ 
$\underline{{ }^{1} \mathrm{H} \text { and }{ }^{13} \mathrm{C} \text { NMR spectrum of compounds (3a-3d) }}$

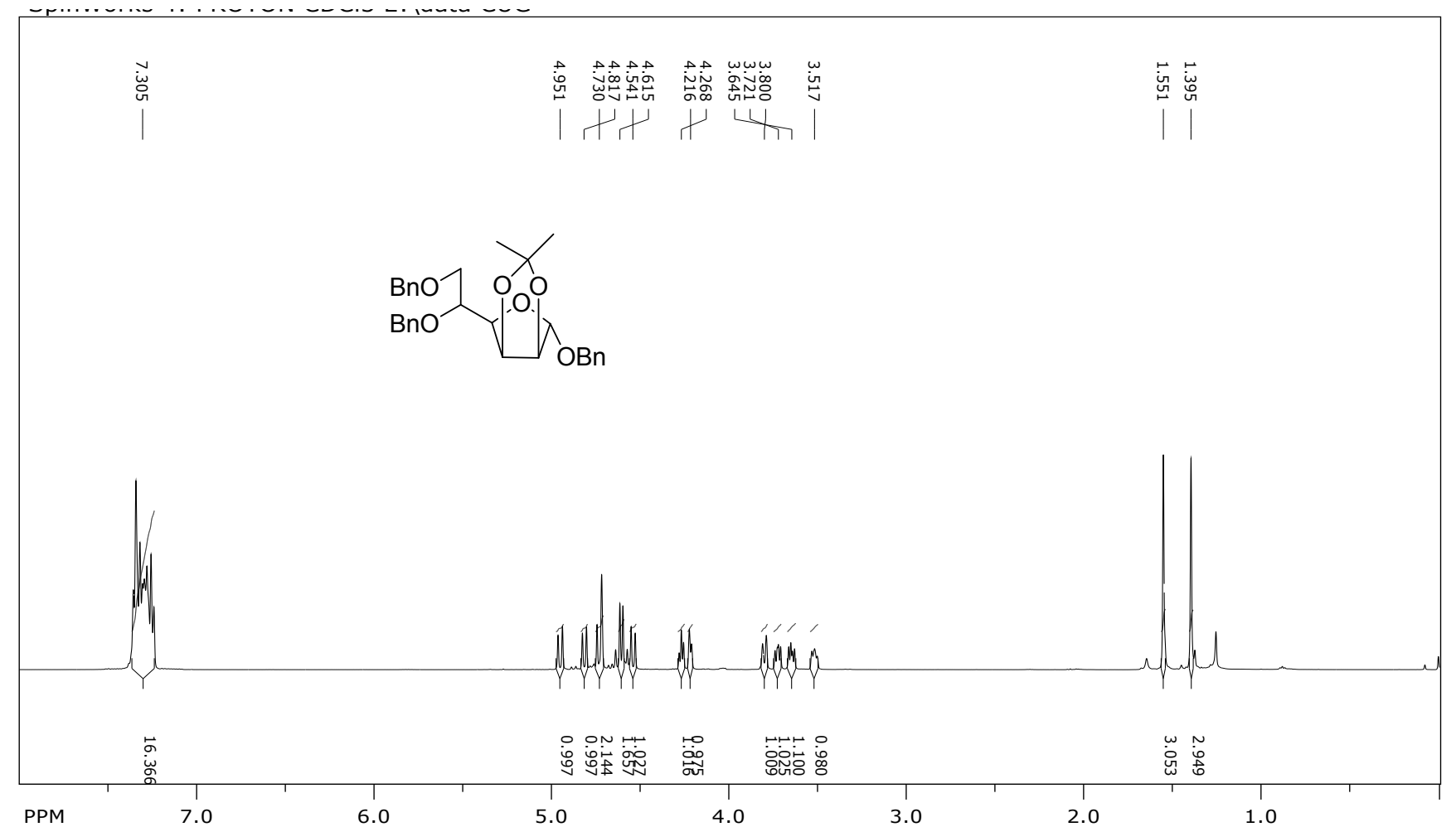

Figure S75. ${ }^{1} \mathrm{H}$ NMR of compound $\mathbf{3 a}$ in $\mathrm{CDCl}_{3}$ at $500 \mathrm{MHz}$ 
Spin Works 4: C13CPD CDCl3 E: \data CUG

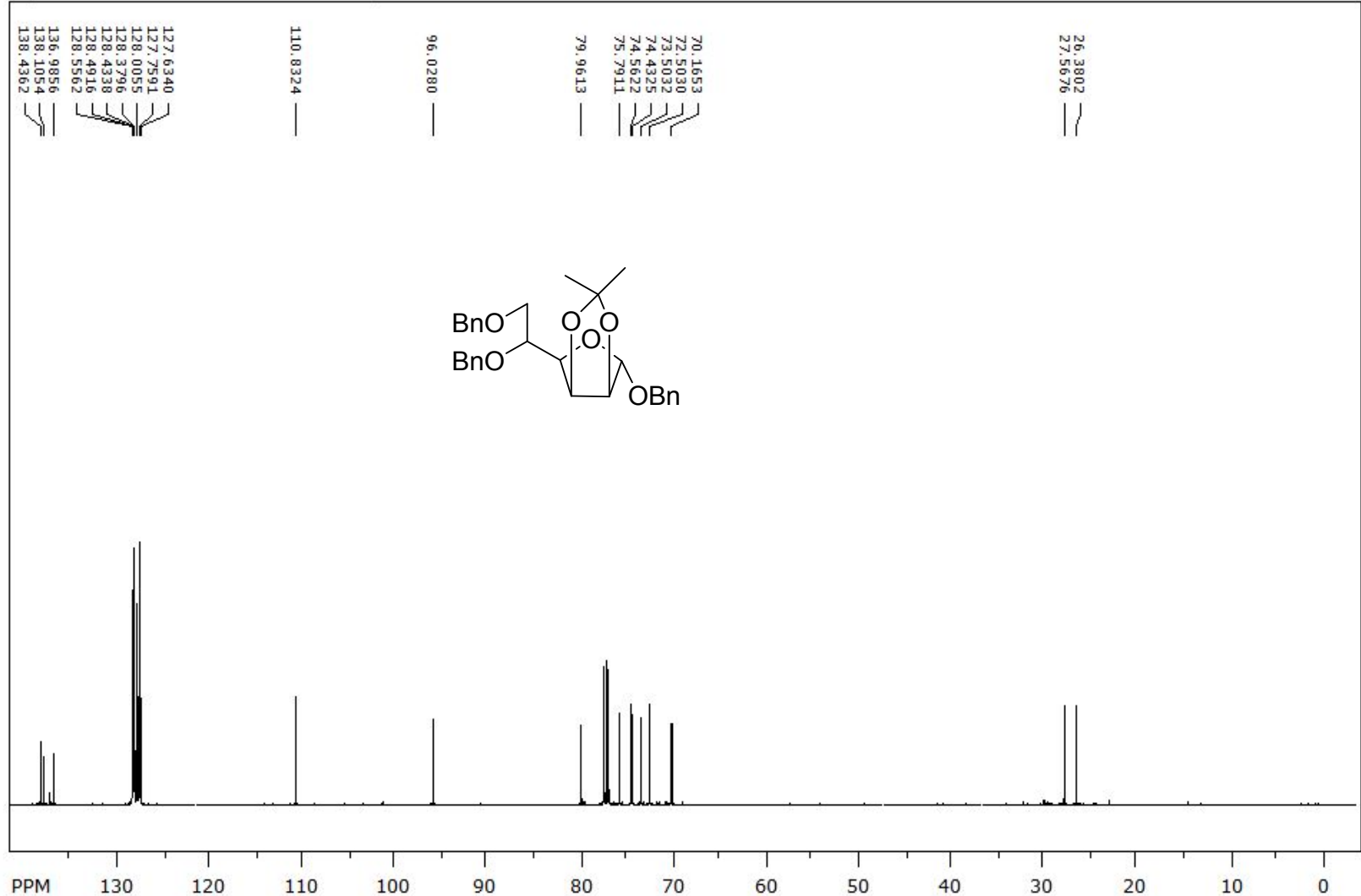

Figure $\mathbf{S 7 6 .}{ }^{13} \mathrm{C}$ NMR of compound $\mathbf{3 a}$ in $\mathrm{CDCl}_{3}$ at $500 \mathrm{MHz}$ 
SpinWorks 4: PROTON CDCl3 E: \data CUG

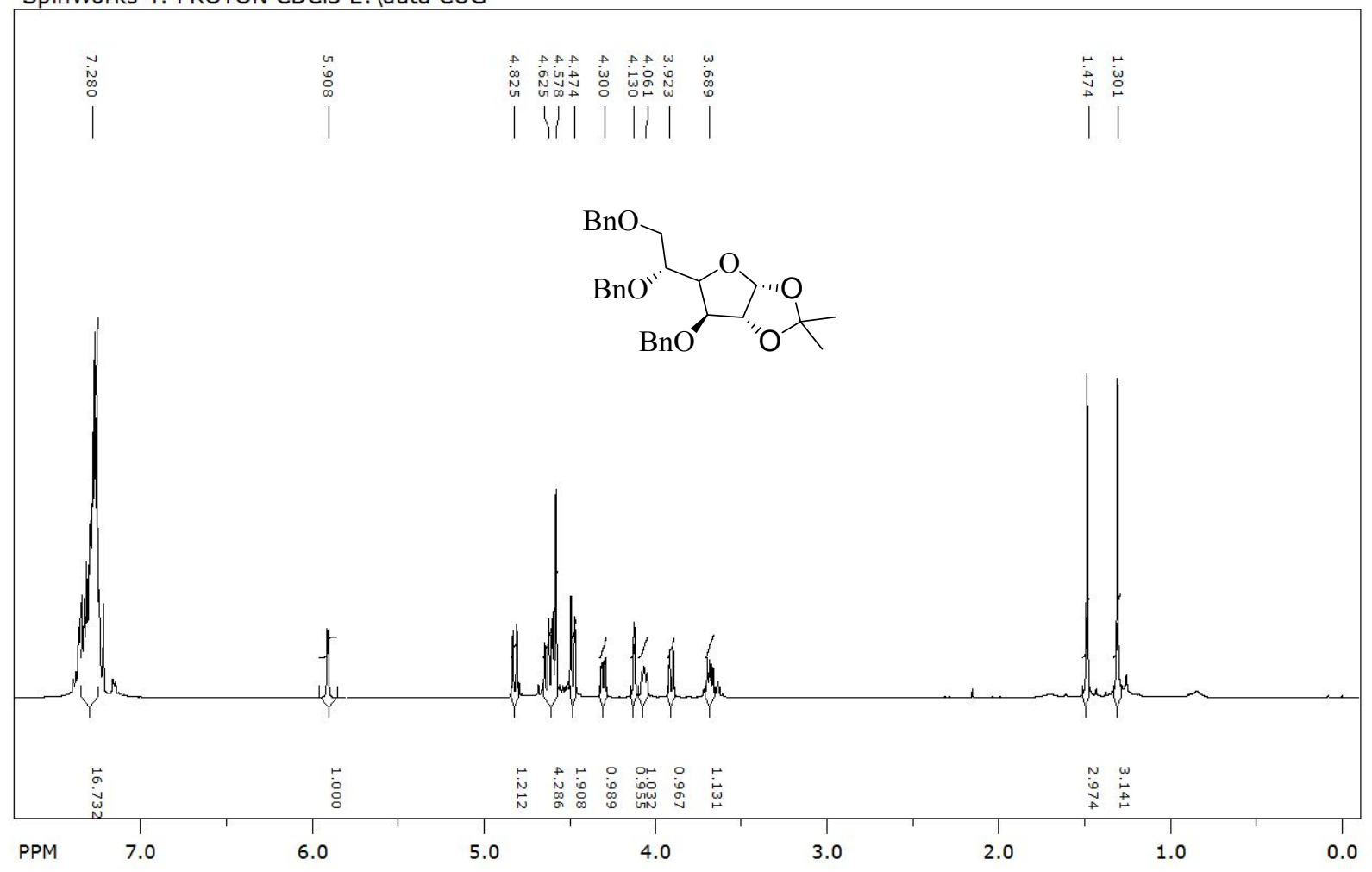

Figure S77. ${ }^{1} \mathrm{H}$ NMR of compound $\mathbf{3 b}$ in $\mathrm{CDCl}_{3}$ at $500 \mathrm{MHz}$ 


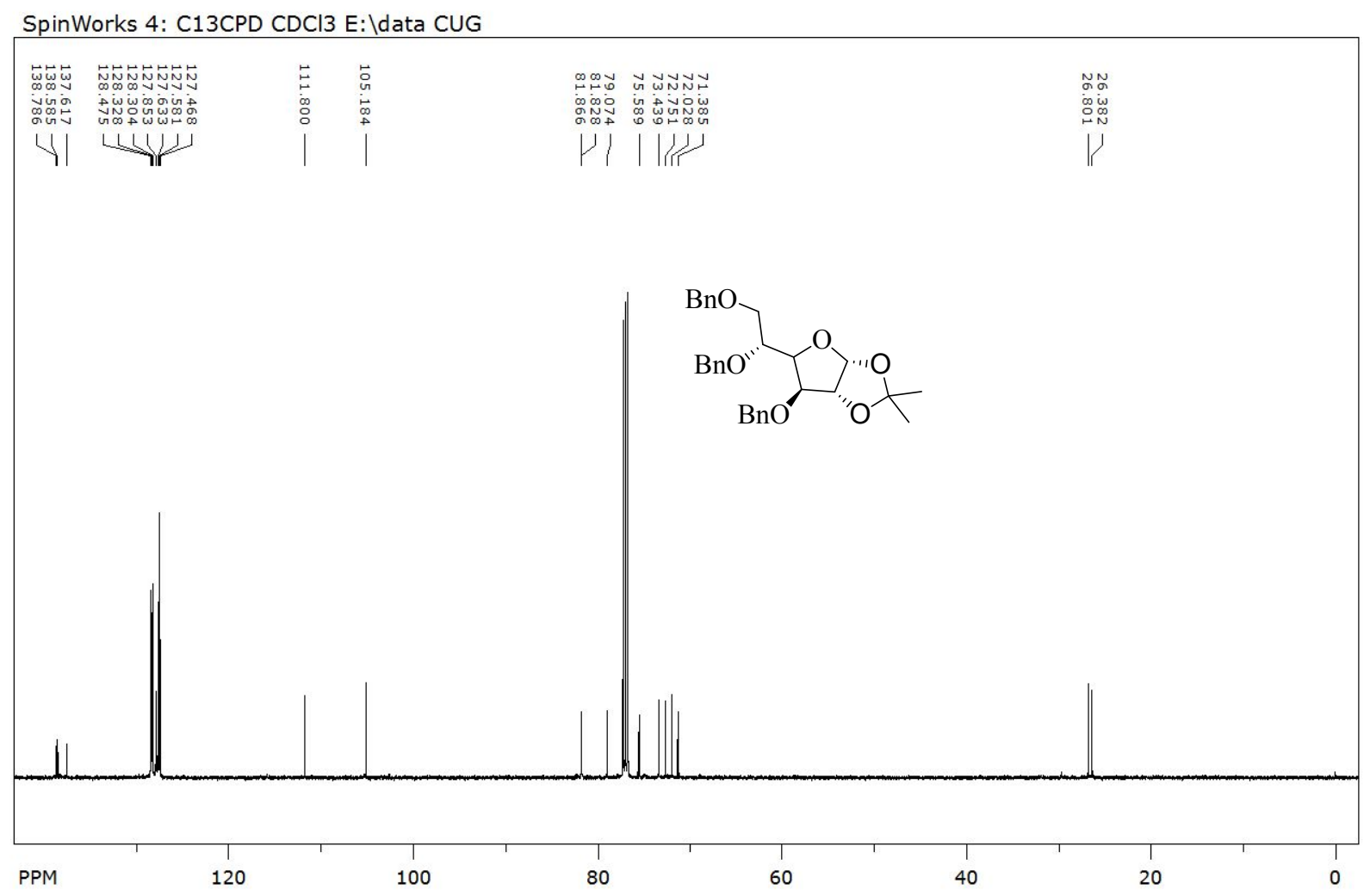

Figure S78. ${ }^{13} \mathrm{C}$ NMR of compound $\mathbf{3 b}$ in $\mathrm{CDCl}_{3}$ at $500 \mathrm{MHz}$ 


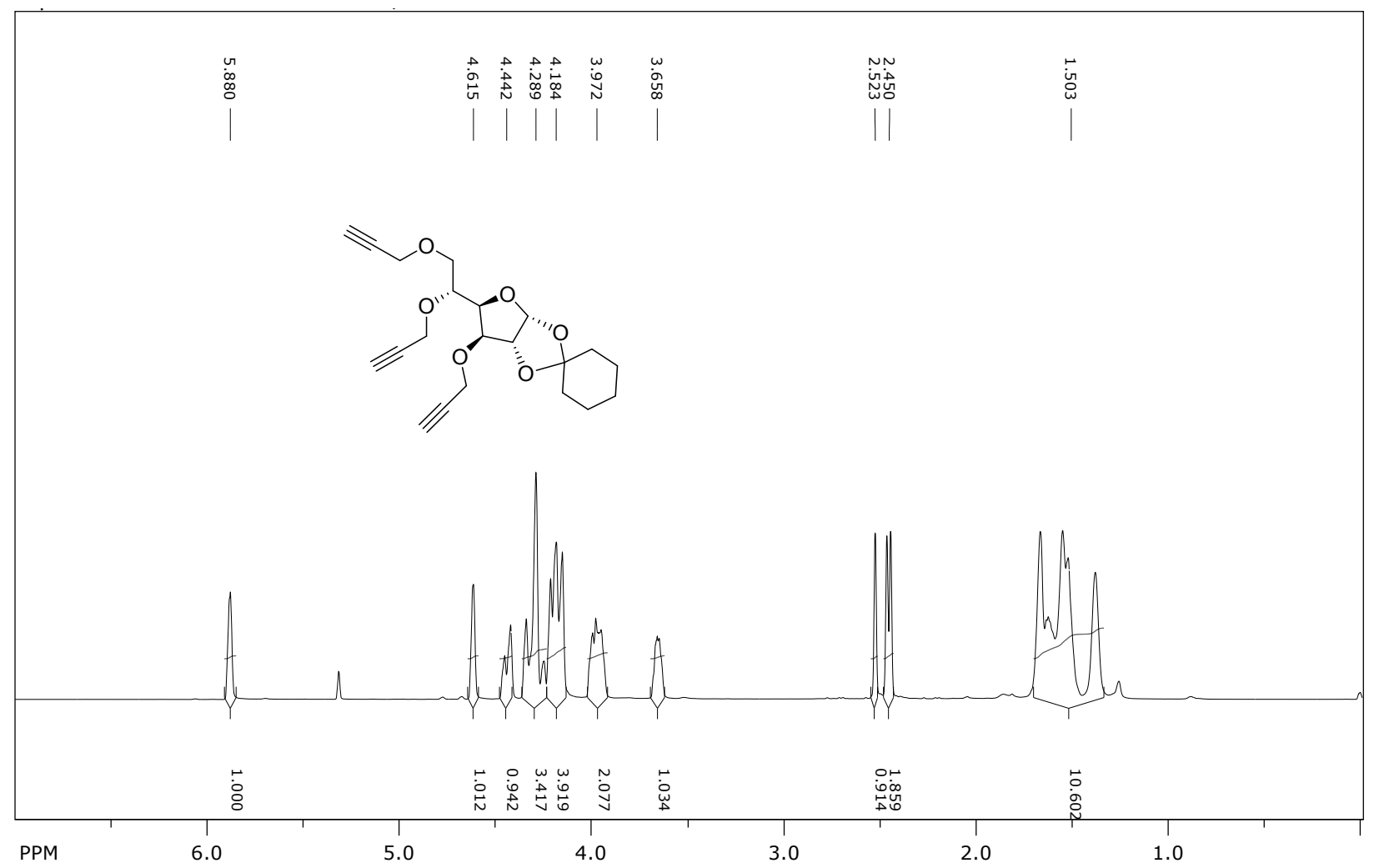

Figure S79. ${ }^{1} \mathrm{H}$ NMR of compound $3 \mathrm{c}$ in $\mathrm{CDCl}_{3}$ at $500 \mathrm{MHz}$ 


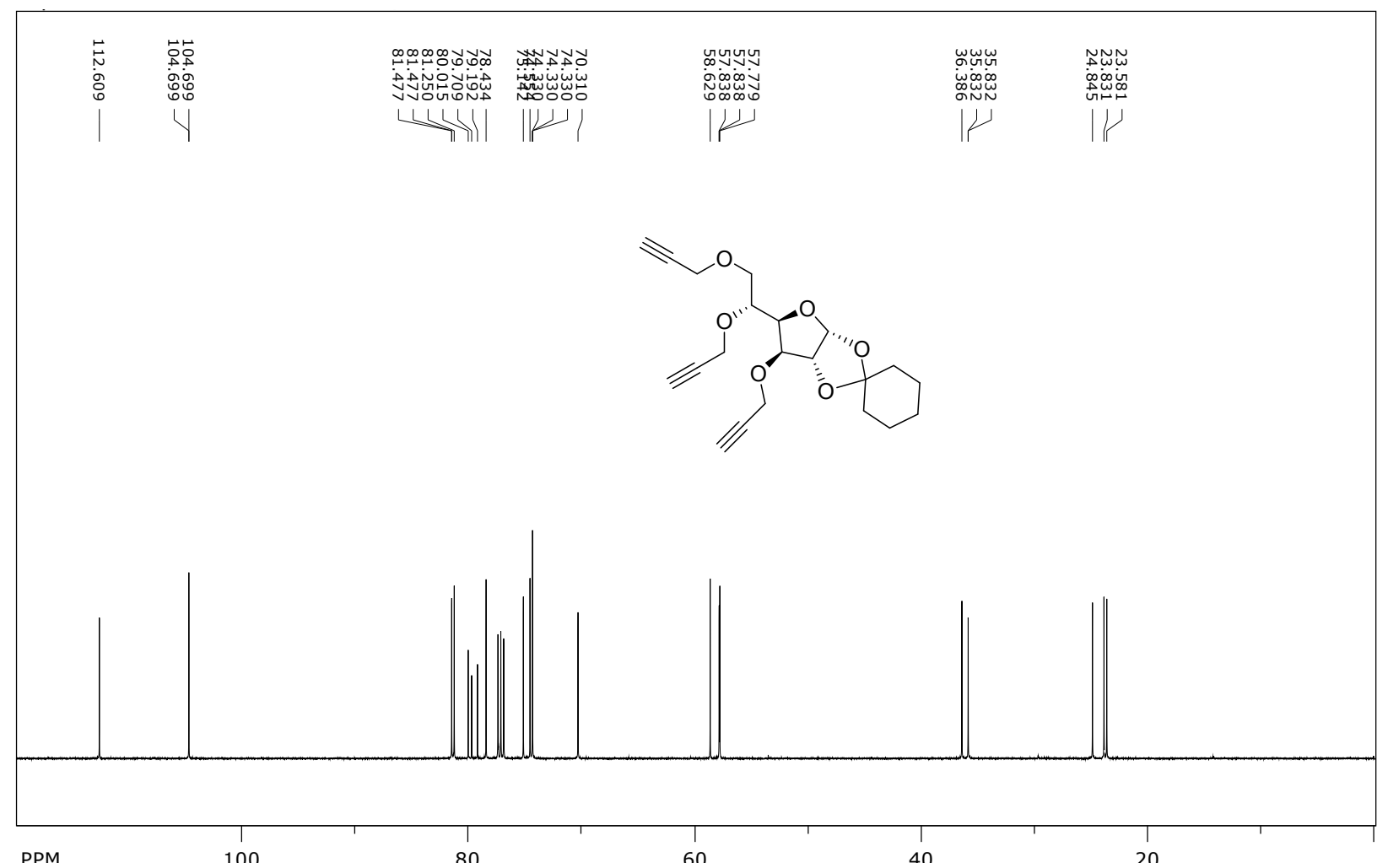

Figure S80. ${ }^{13} \mathrm{C}$ NMR of compound $3 \mathbf{c}$ in $\mathrm{CDCl}_{3}$ at $500 \mathrm{MHz}$ 


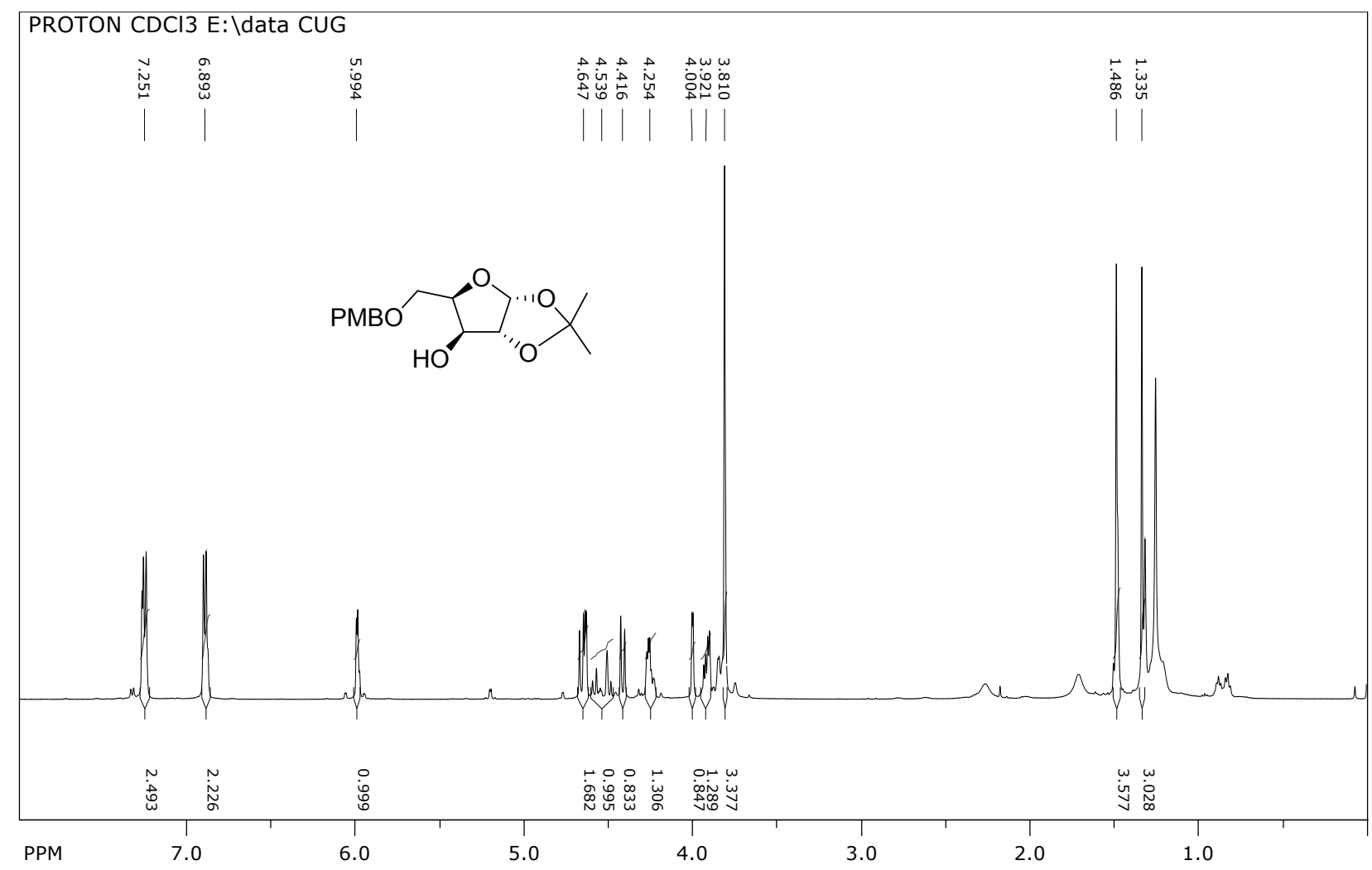

Figure S81. ${ }^{1} \mathrm{H}$ NMR of compound 3d in $\mathrm{CDCl}_{3}$ at $500 \mathrm{MHz}$ 


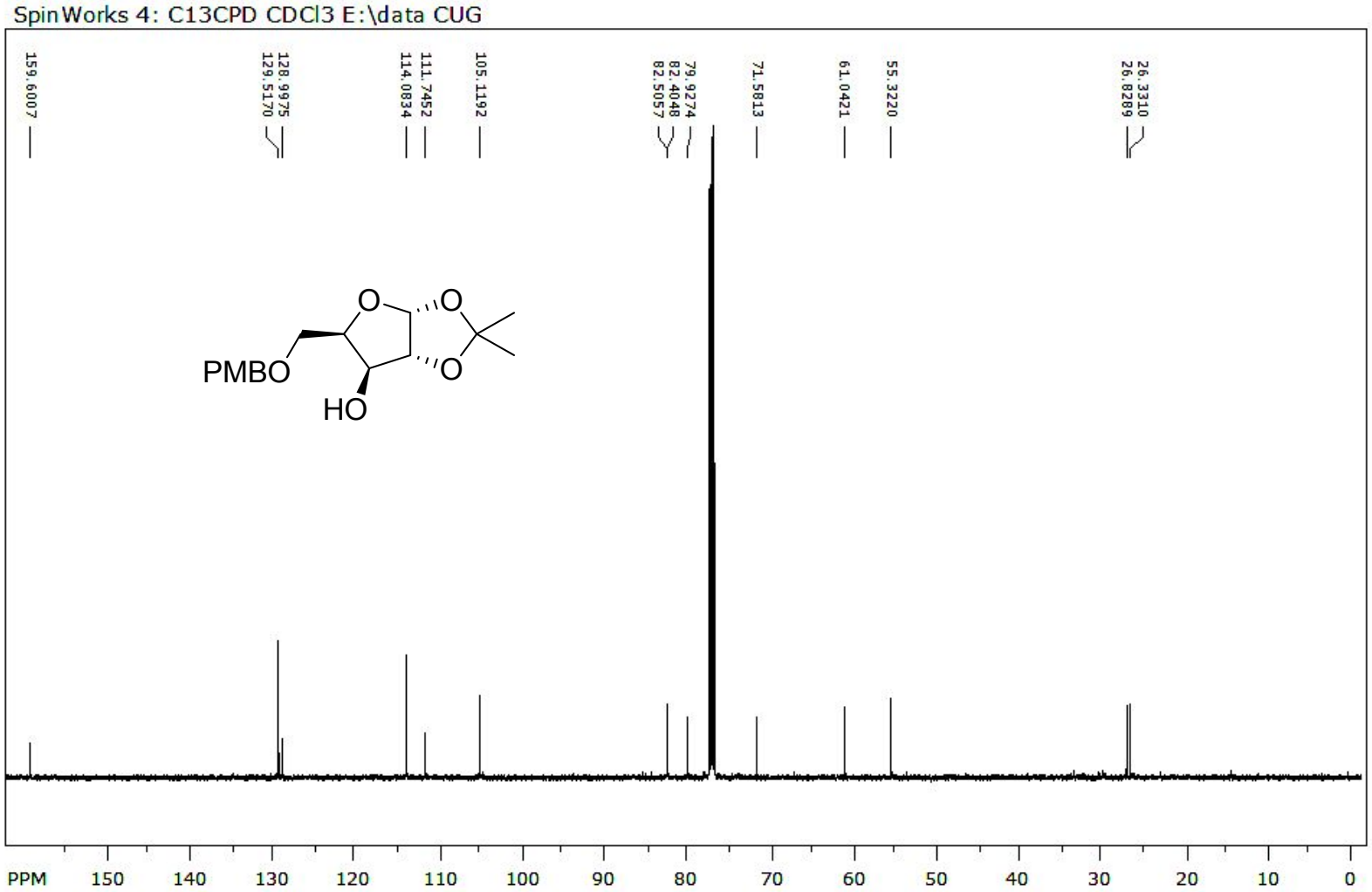

Figure S82. ${ }^{13} \mathrm{C} \mathrm{NMR}$ of compound 3d in $\mathrm{CDCl}_{3}$ at $500 \mathrm{MHz}$ 


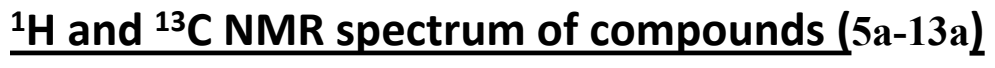

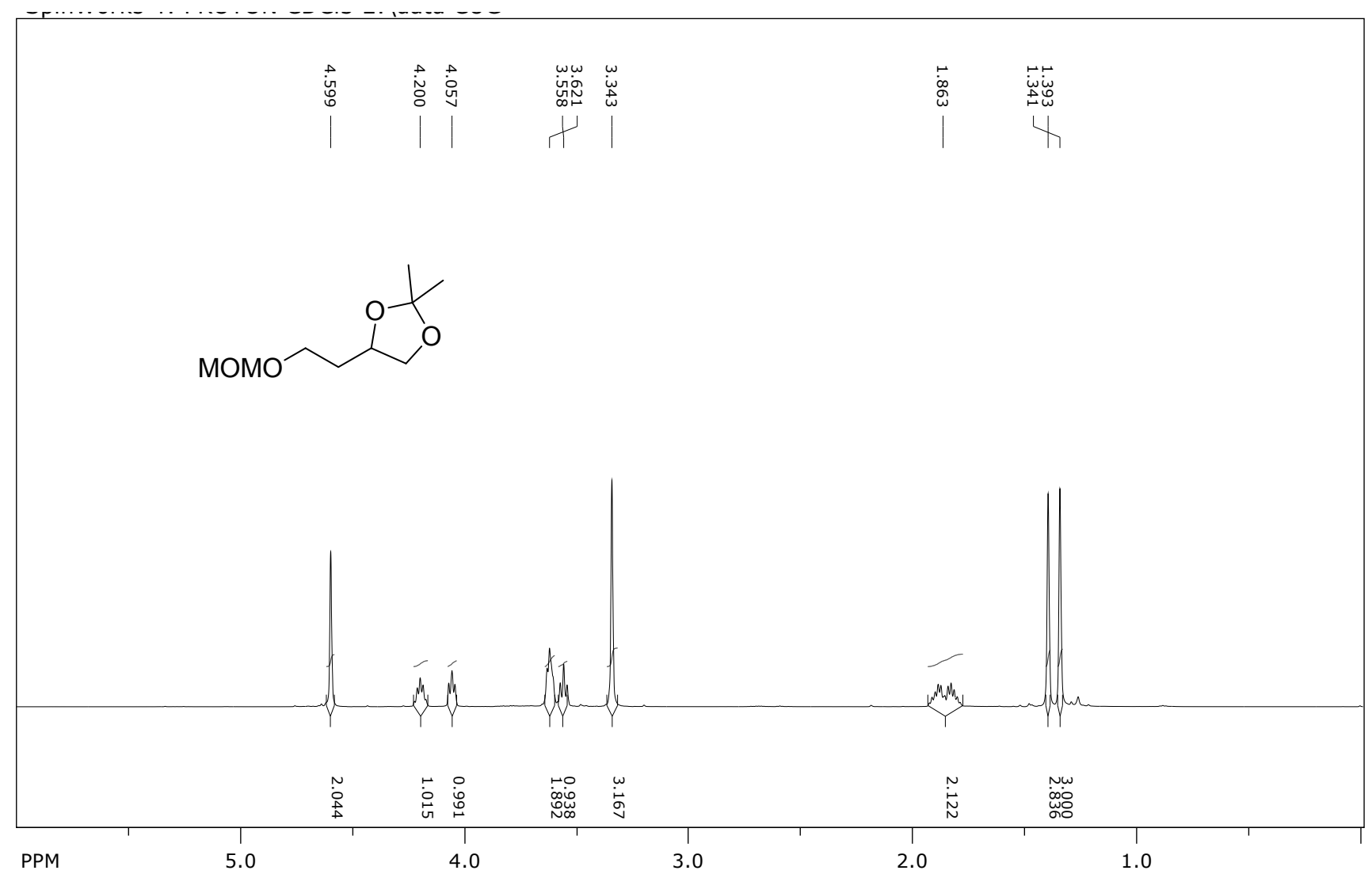

Figure S83. ${ }^{1} \mathrm{H}$ NMR of compound 5a in $\mathrm{CDCl}_{3}$ at $500 \mathrm{MHz}$ 


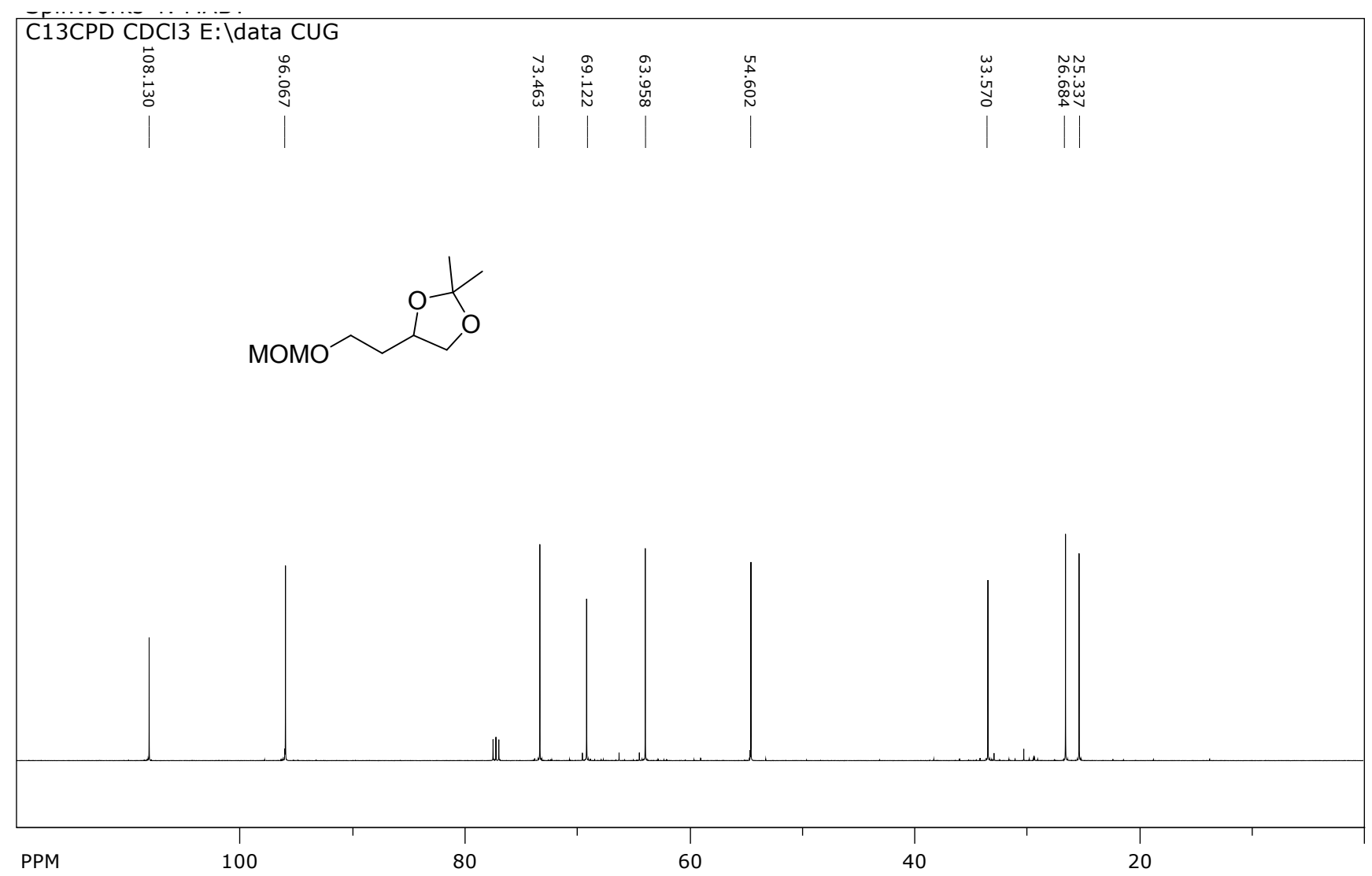

Figure S84. ${ }^{13} \mathrm{C}$ NMR of compound $\mathbf{5 a}$ in $\mathrm{CDCl}_{3}$ at $500 \mathrm{MHz}$ 


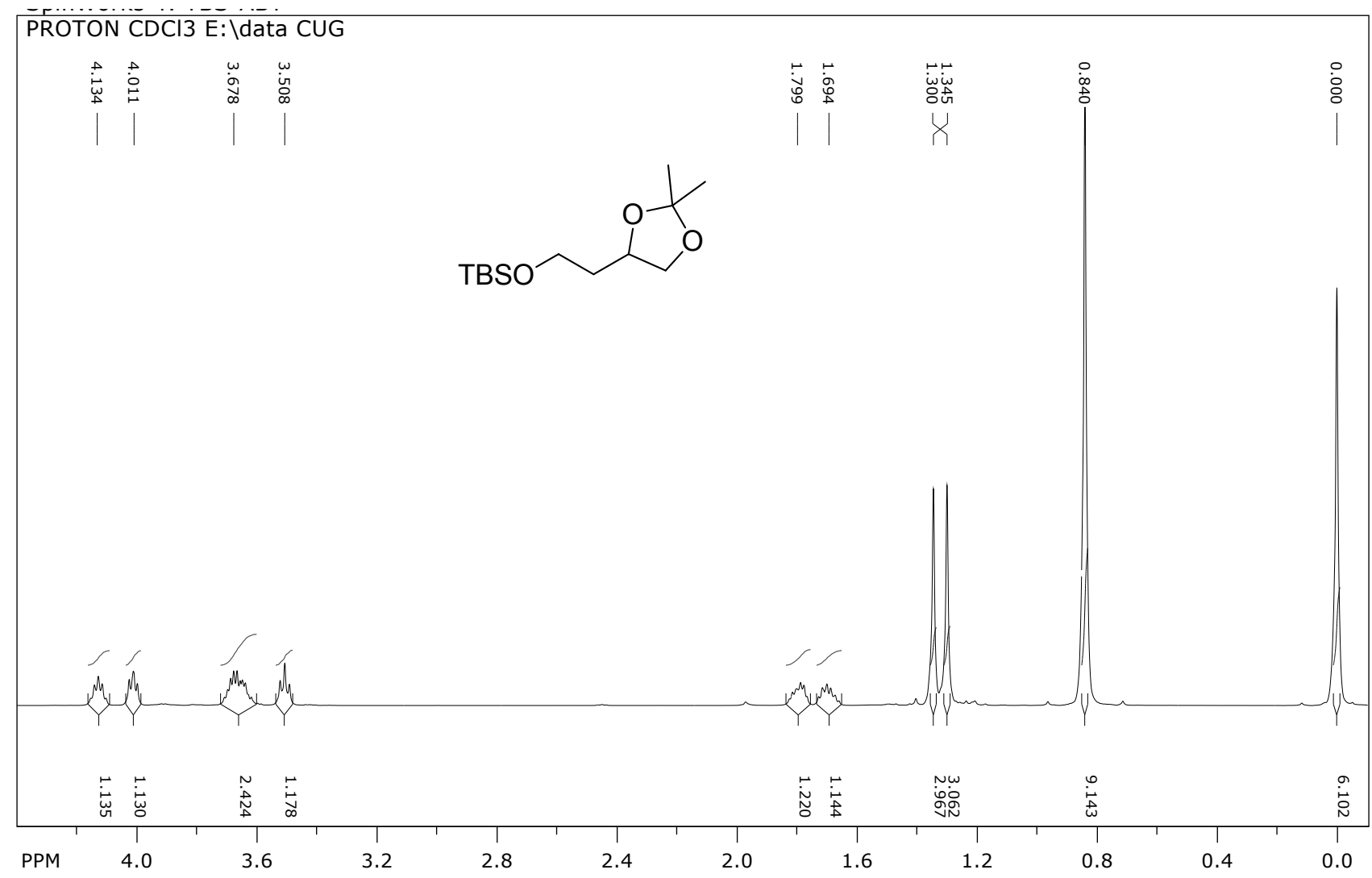

Figure S85. ${ }^{1} \mathrm{H} \mathrm{NMR}$ of compound $\mathbf{6 a}$ in $\mathrm{CDCl}_{3}$ at $500 \mathrm{MHz}$ 


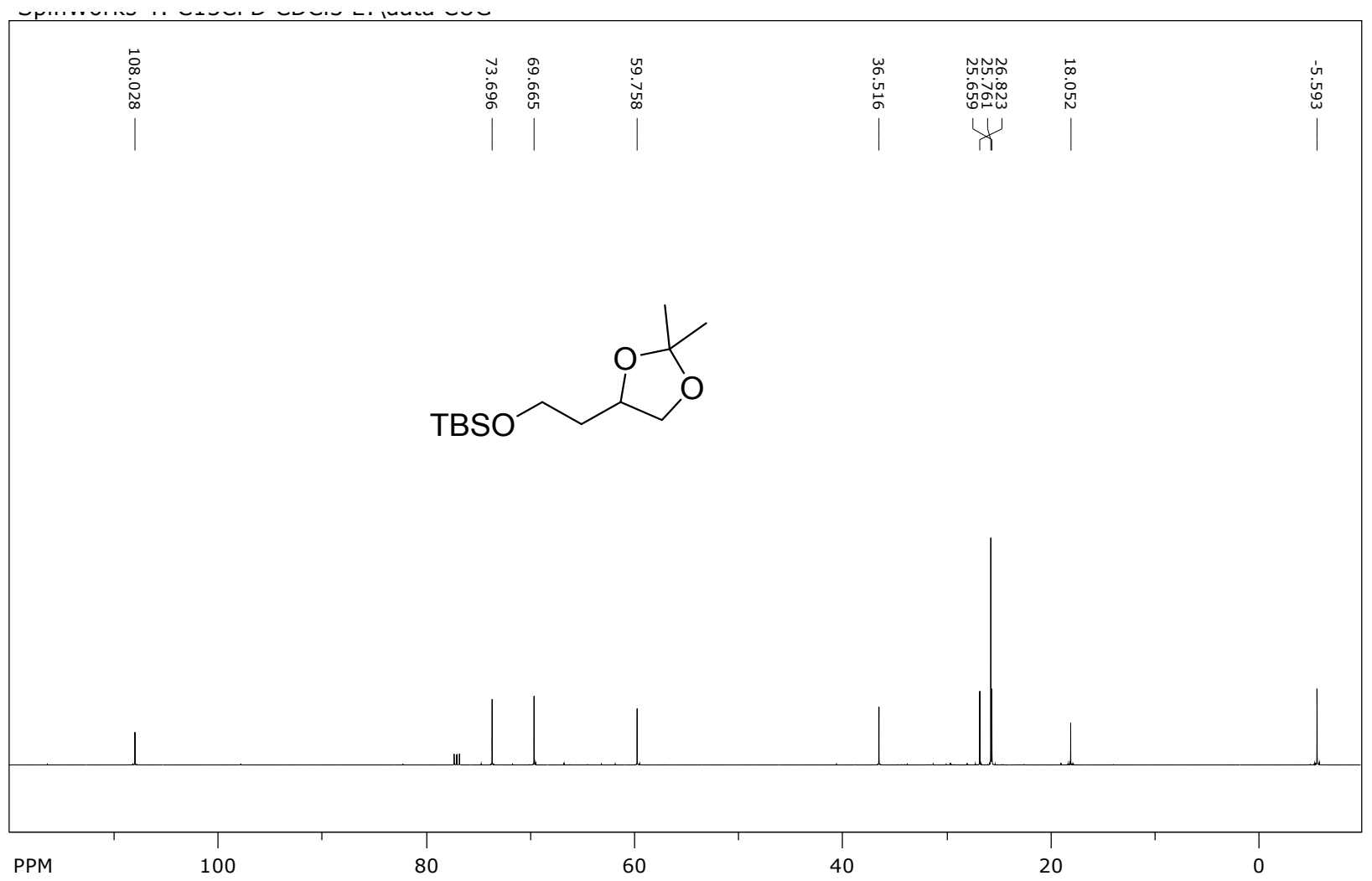

Figure S86. ${ }^{13} \mathrm{C}$ NMR of compound 6 a in $\mathrm{CDCl}_{3}$ at $500 \mathrm{MHz}$ 


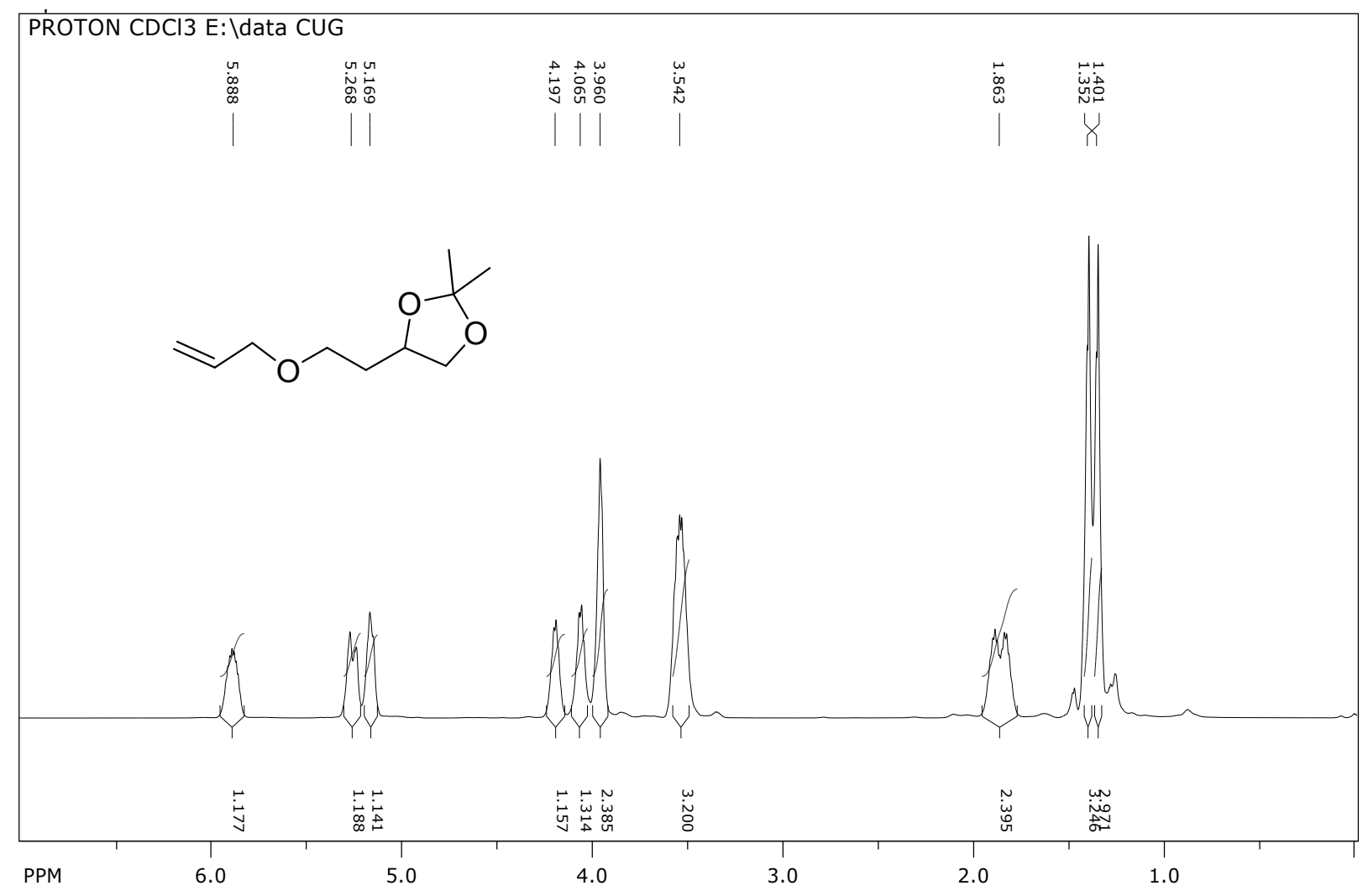

Figure S87. ${ }^{1} \mathrm{H}$ NMR of compound $7 \mathbf{a}$ in $\mathrm{CDCl}_{3}$ at $500 \mathrm{MHz}$ 


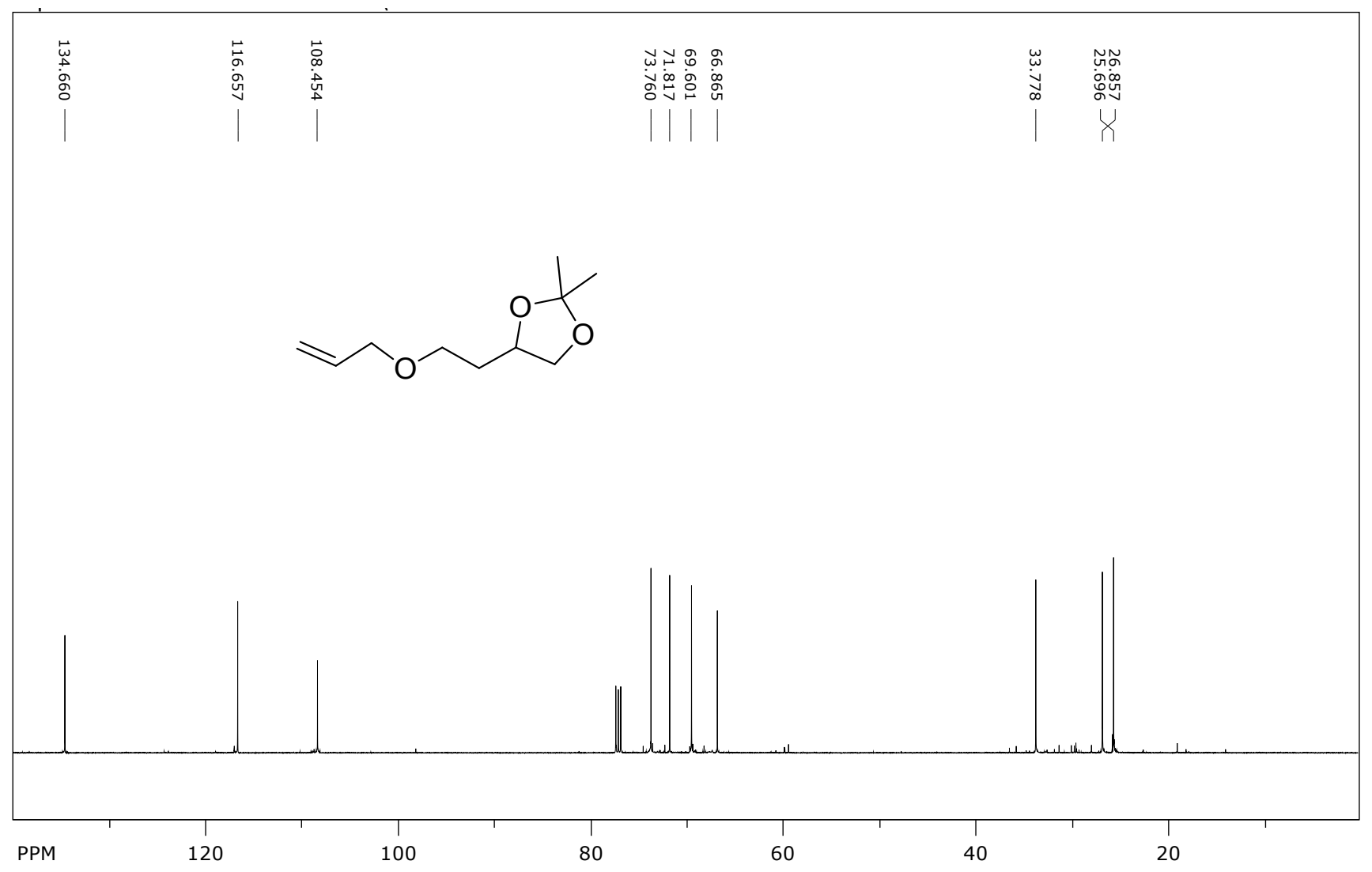

Figure S88. ${ }^{13} \mathrm{C}$ NMR of $7 \mathbf{a}$ in $\mathrm{CDCl}_{3}$ at $500 \mathrm{MHz}$ 


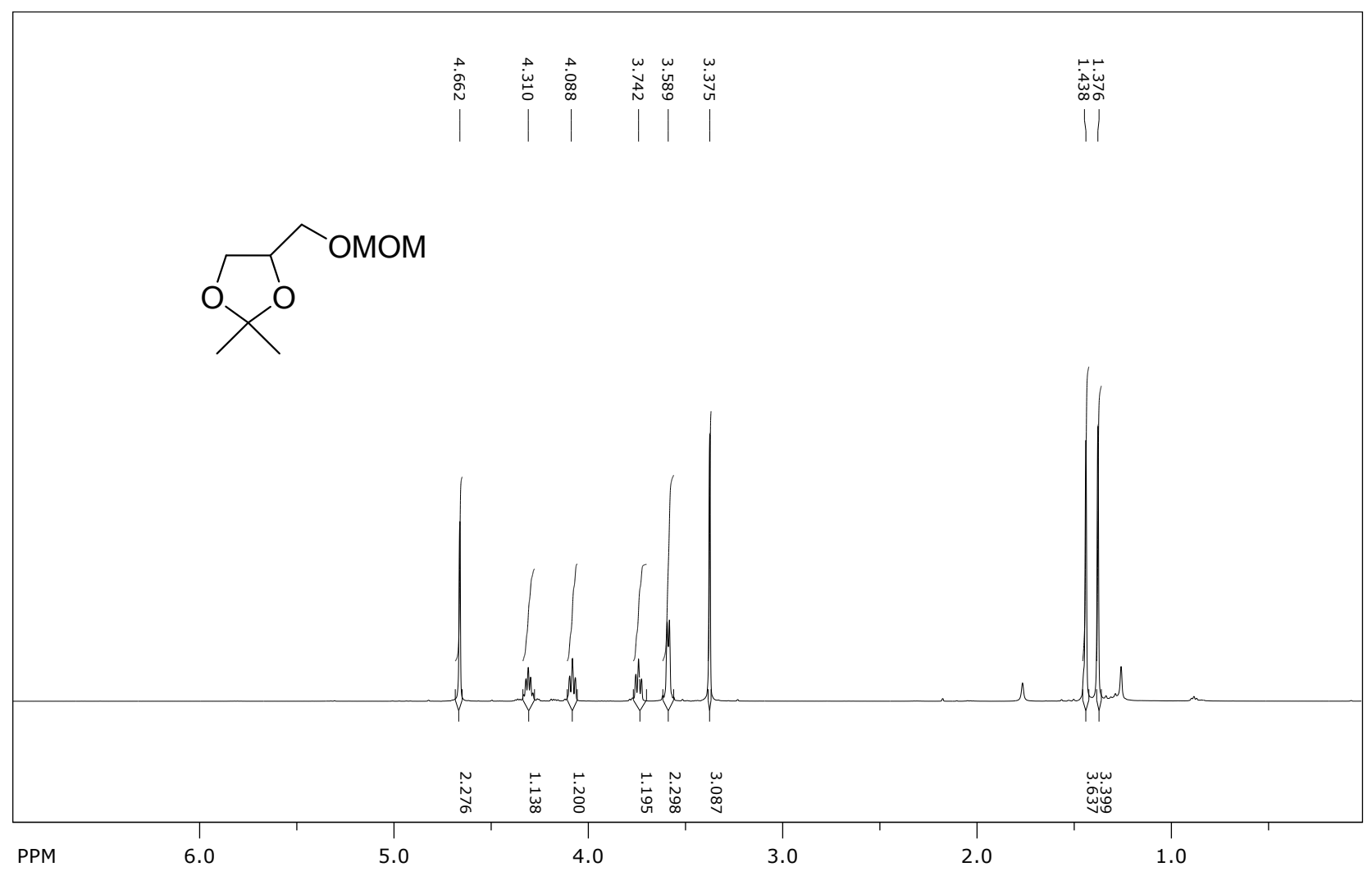

Figure S89. ${ }^{1} \mathrm{H} \mathrm{NMR}$ of compound $\mathbf{8 a}$ in $\mathrm{CDCl}_{3}$ at $500 \mathrm{MHz}$ 


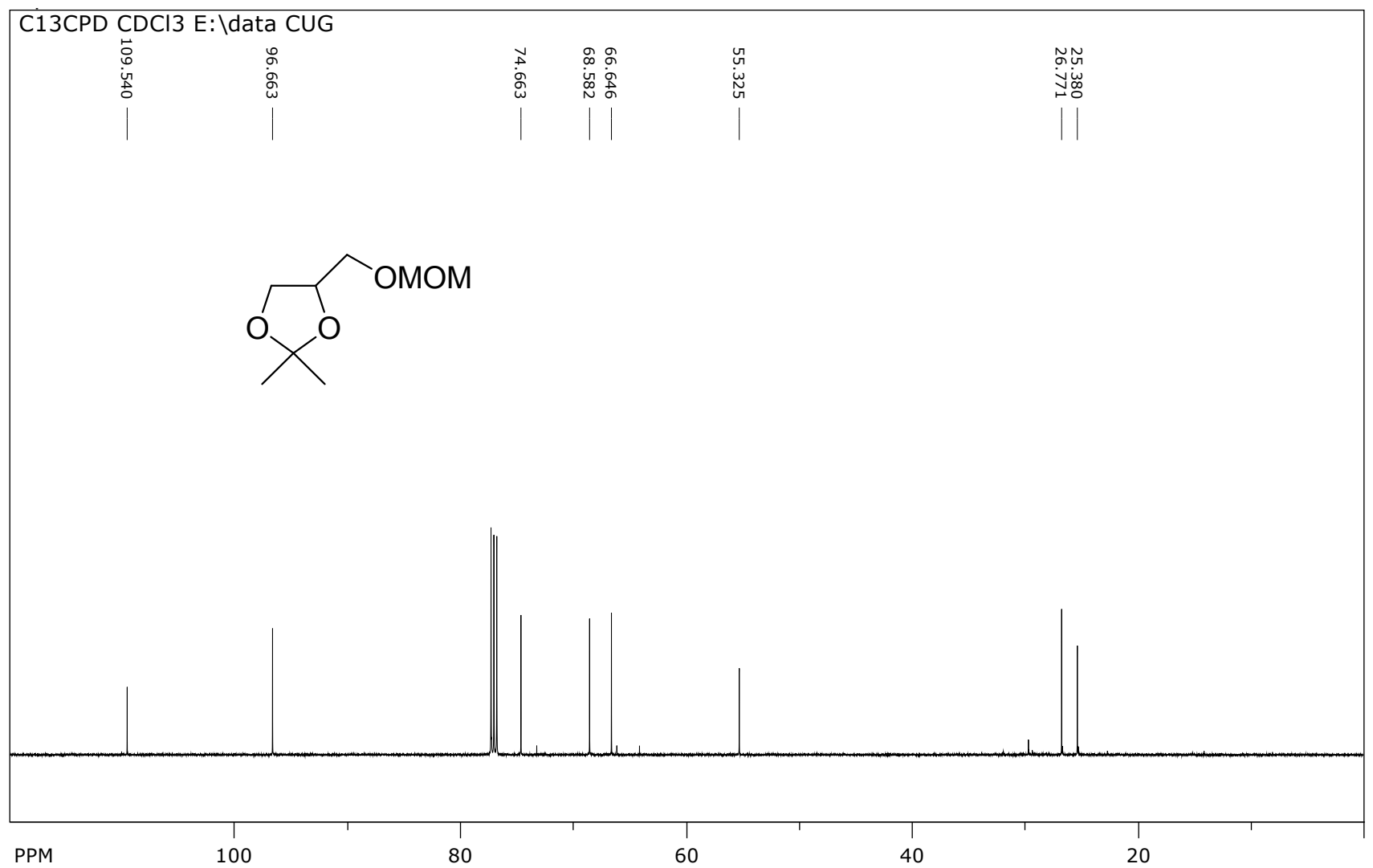

Figure S90. ${ }^{13} \mathrm{C} \mathrm{NMR}$ of compound $8 \mathbf{a}$ in $\mathrm{CDCl}_{3}$ at $500 \mathrm{MHz}$ 


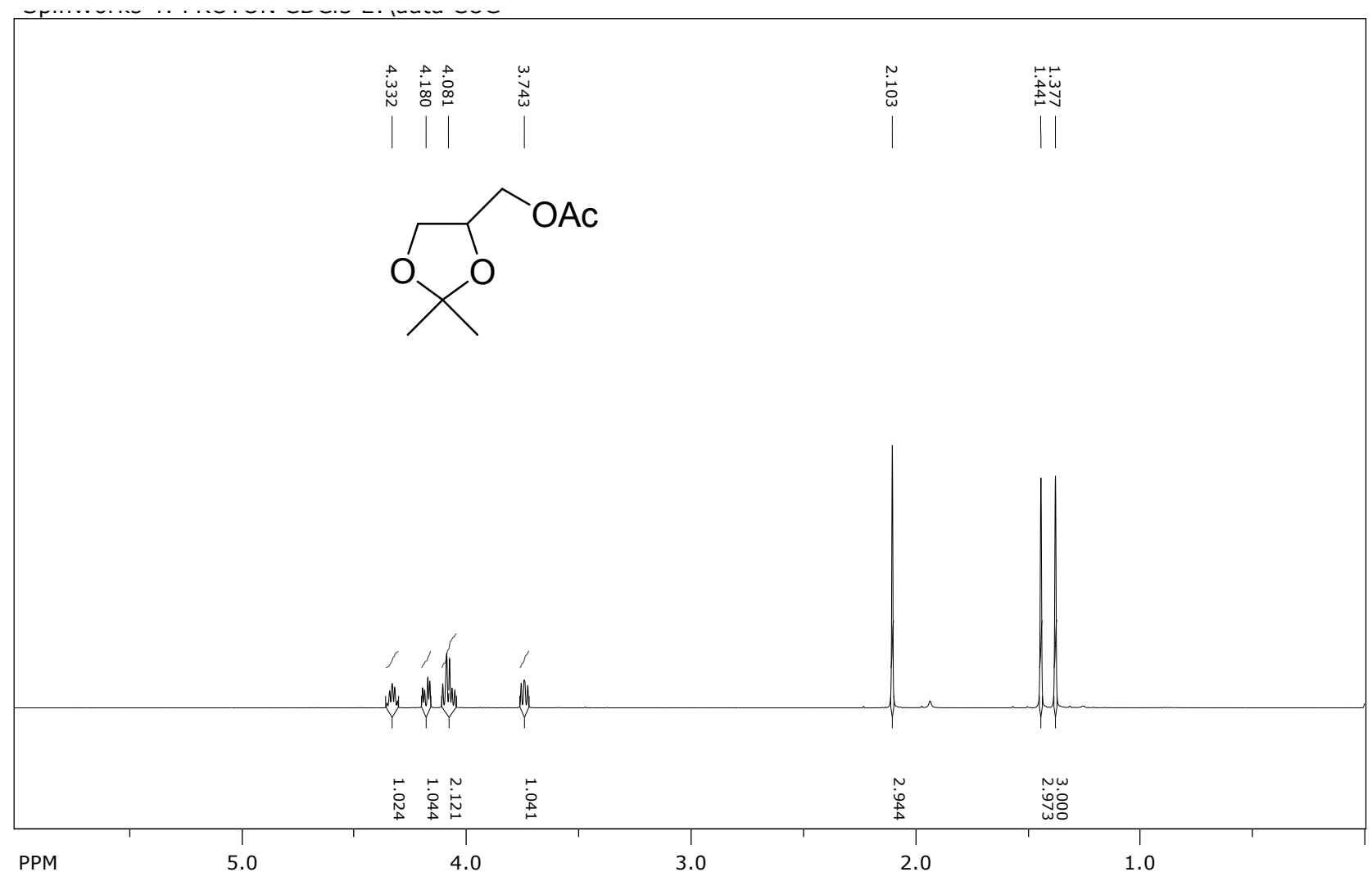

Figure S91. ${ }^{1} \mathrm{H} \mathrm{NMR}$ of compound 9a in $\mathrm{CDCl}_{3}$ at $500 \mathrm{MHz}$ 


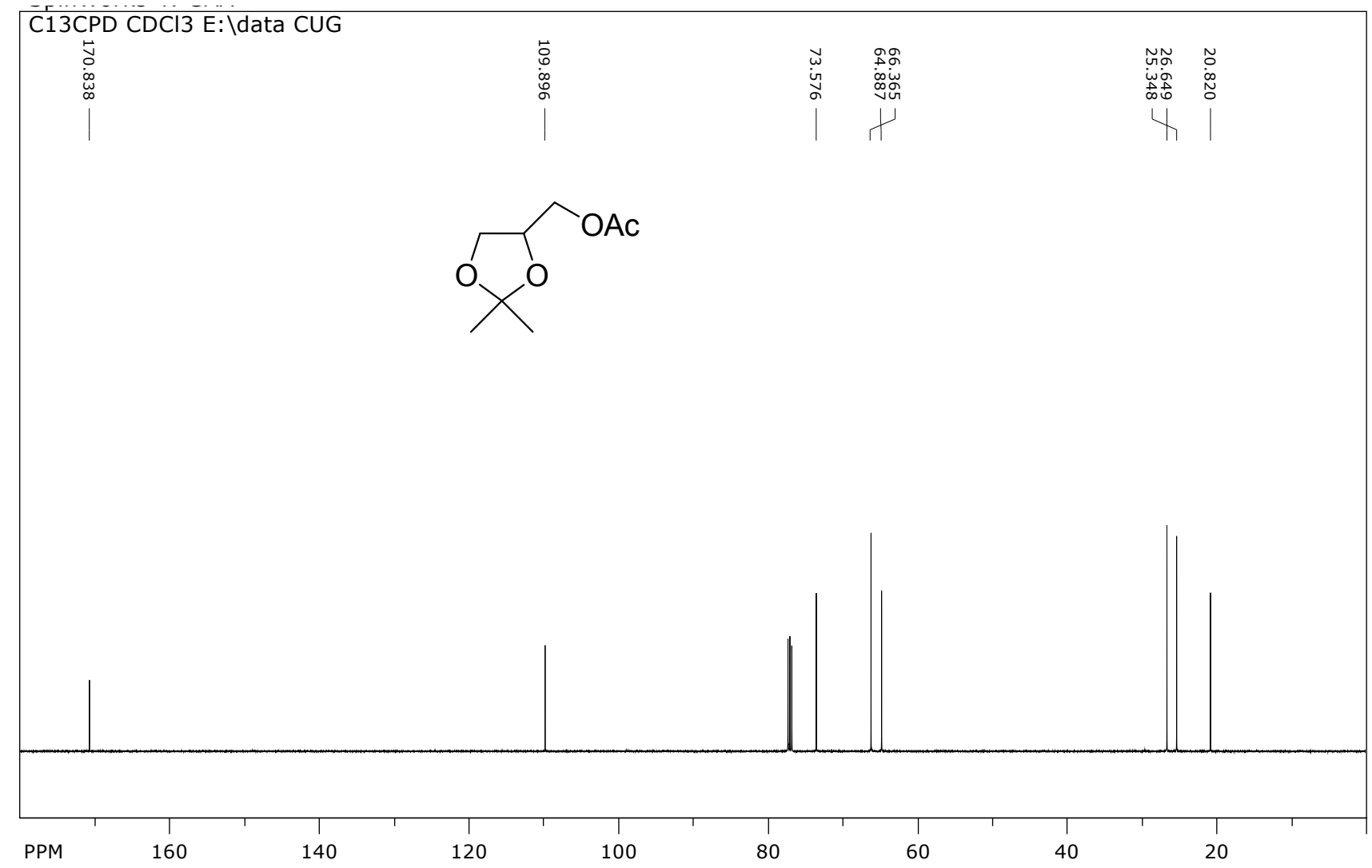

Figure S92. ${ }^{13} \mathrm{C} \mathrm{NMR}$ of compound 9a in $\mathrm{CDCl}_{3}$ at $500 \mathrm{MHz}$ 


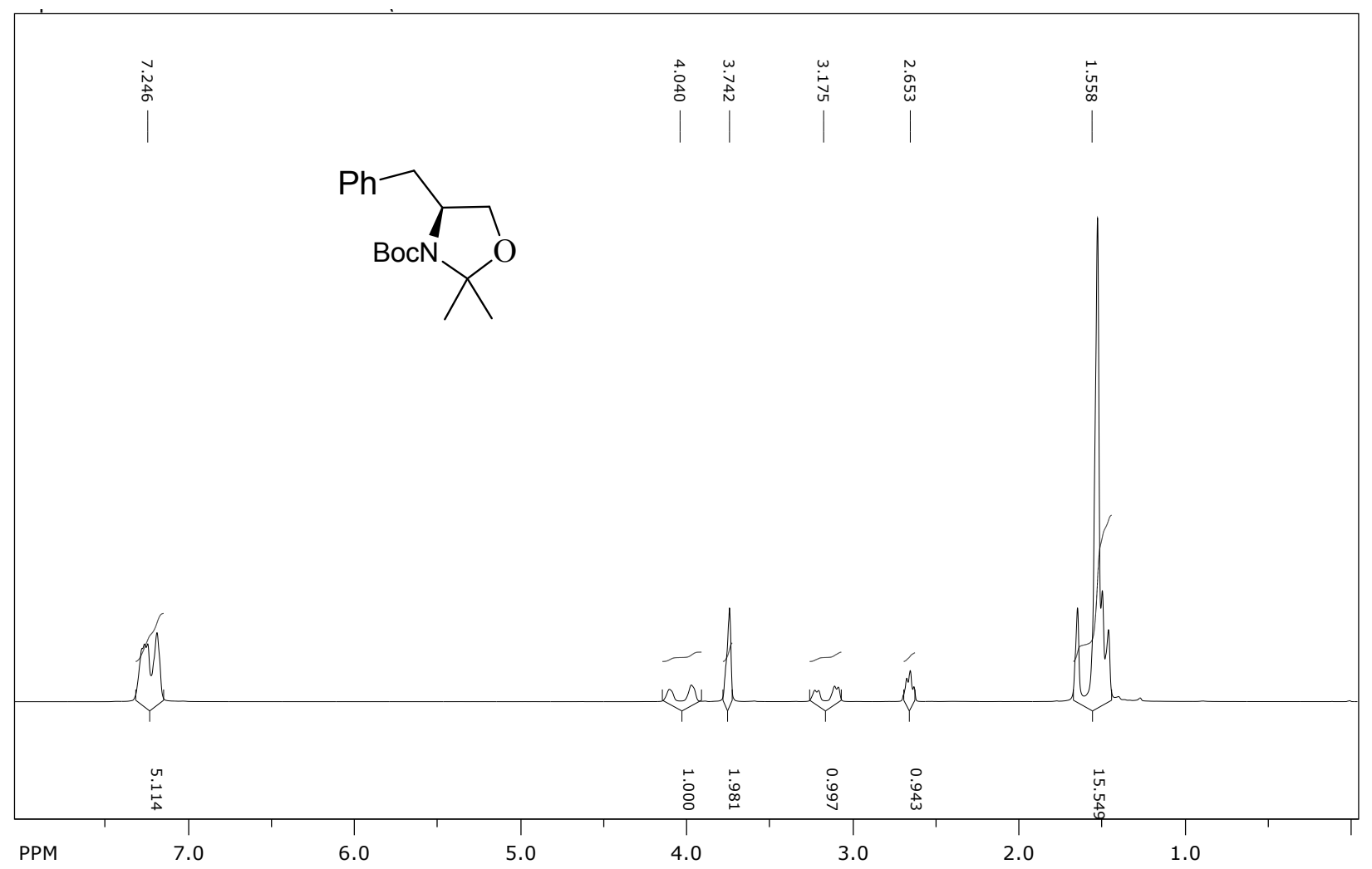

Figure S93. ${ }^{1} \mathrm{H}$ NMR of compound $10 a$ in $\mathrm{CDCl}_{3}$ at $500 \mathrm{MHz}$ 


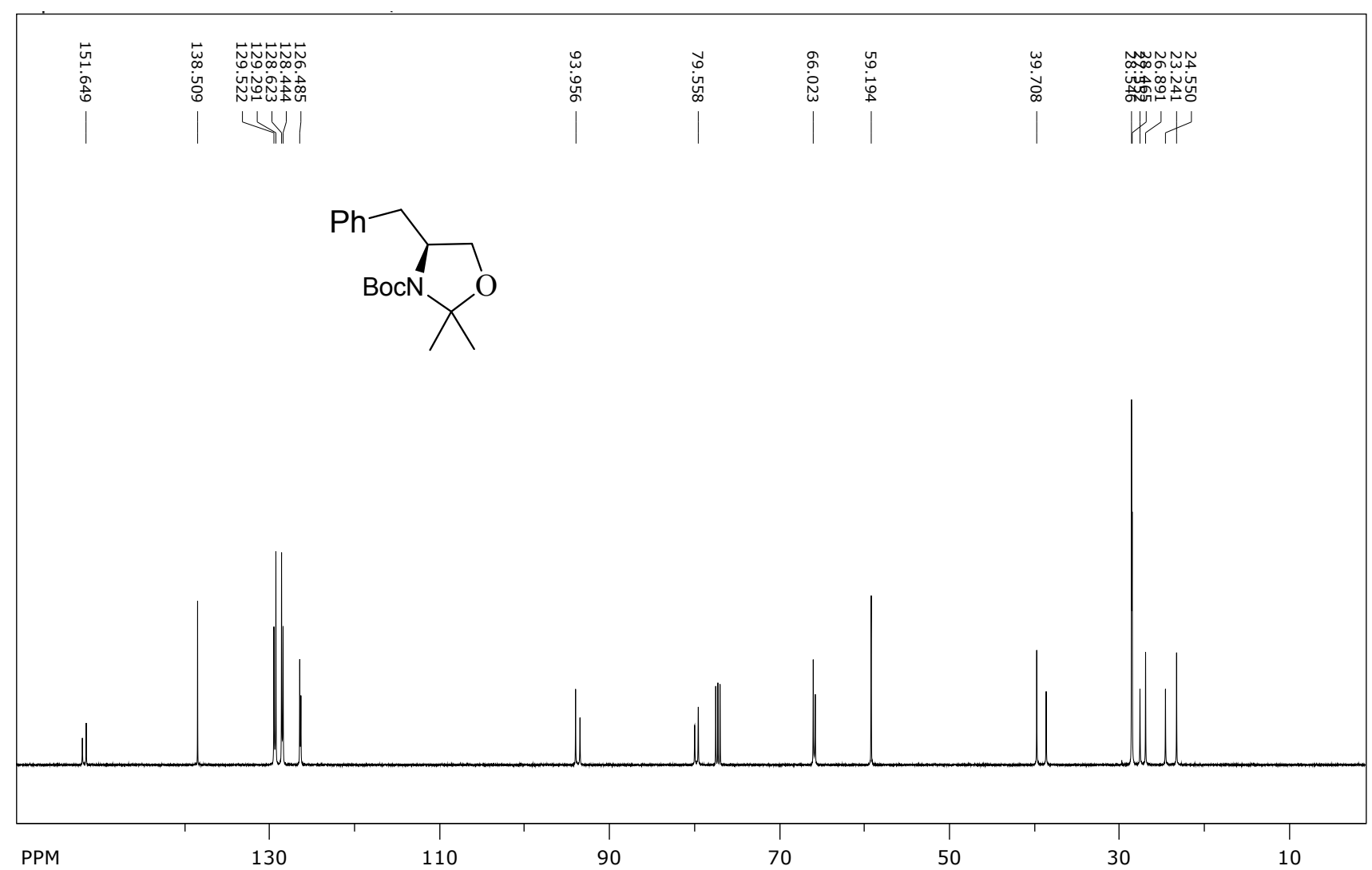

Figure S94. ${ }^{13} \mathrm{C}$ NMR of compound 10a in $\mathrm{CDCl}_{3}$ at $500 \mathrm{MHz}$ 


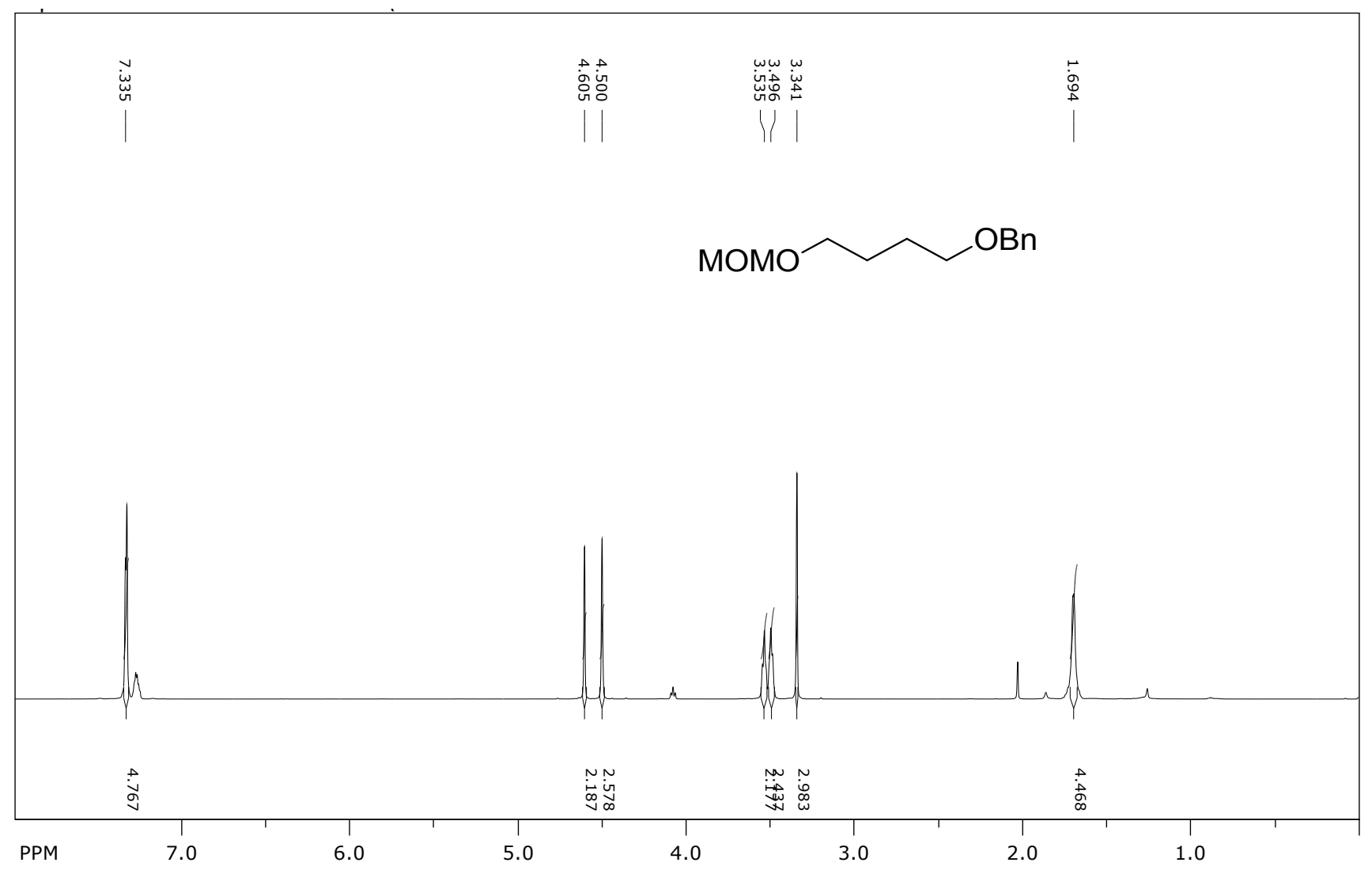

Figure S95. ${ }^{1} \mathrm{H} \mathrm{NMR}$ of compound $\mathbf{1 3 a}$ in $\mathrm{CDCl}_{3}$ at $500 \mathrm{MHz}$ 


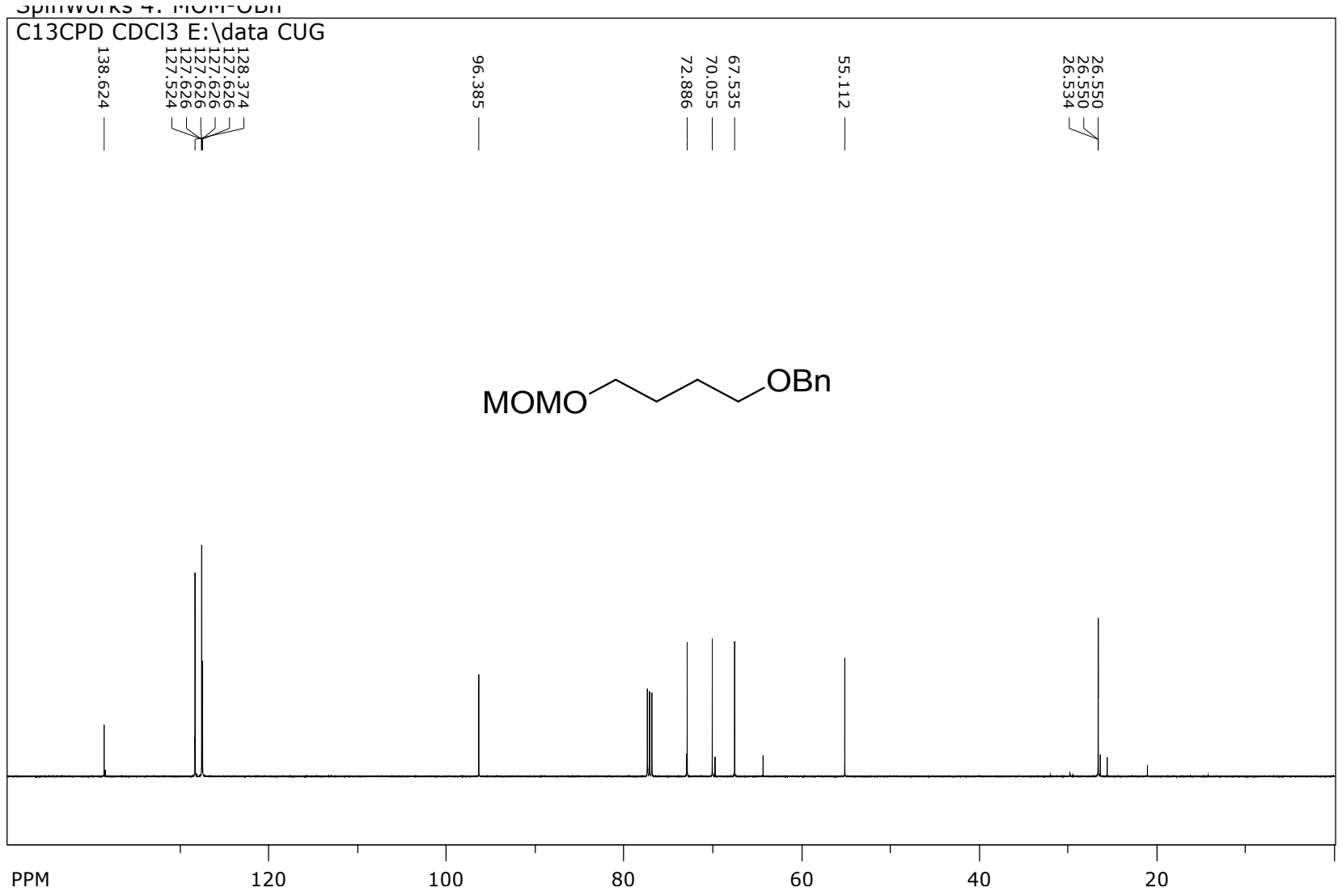

Figure S96. ${ }^{13} \mathrm{C} \mathrm{NMR}$ of compound 13a in $\mathrm{CDCl}_{3}$ at $500 \mathrm{MHz}$ 


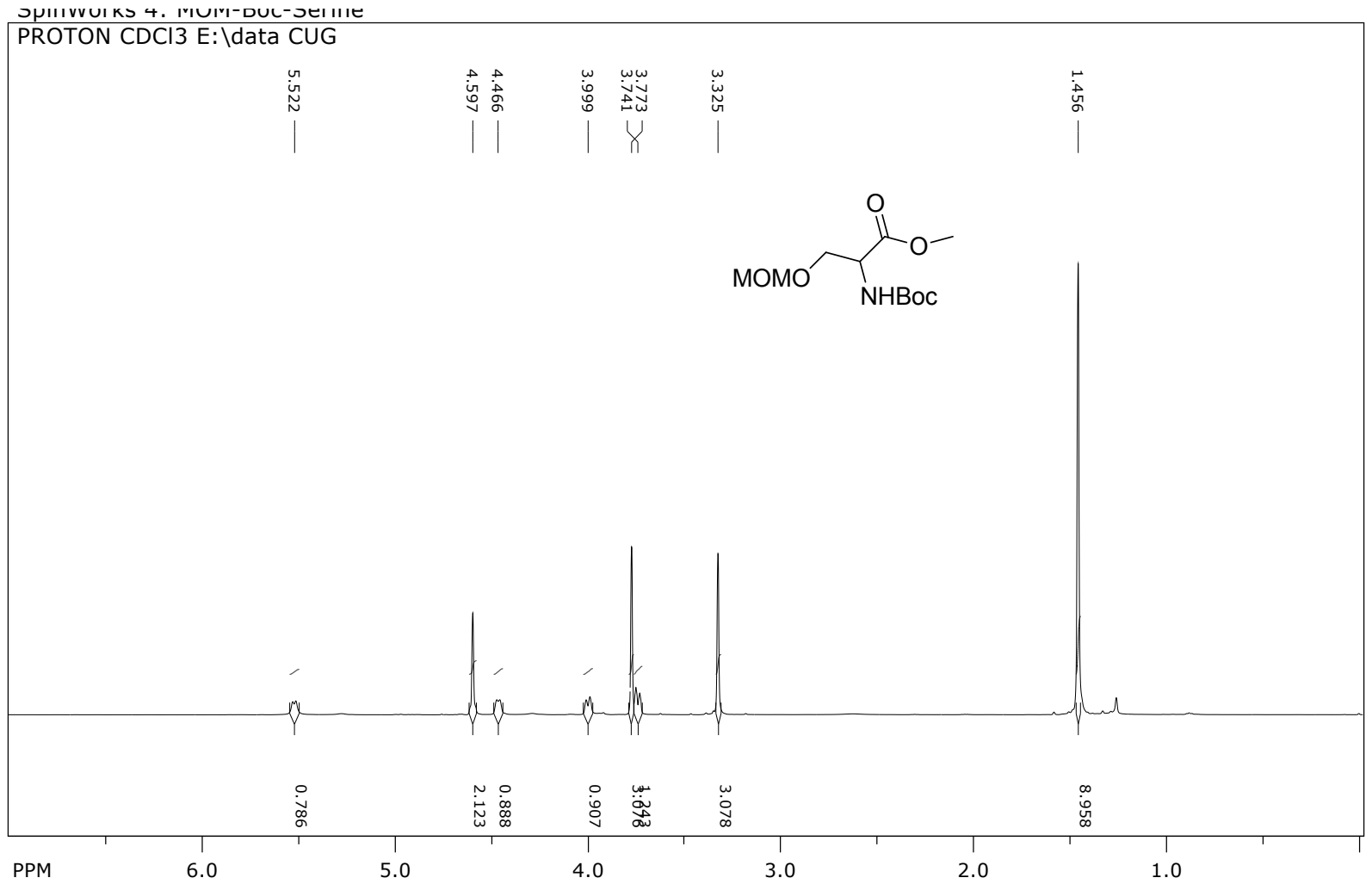

Figure 97: ${ }^{1} \mathrm{H} \mathrm{NMR}$ of compound14a in $\mathrm{CDCl}_{3}$ at $500 \mathrm{MHz}$ 


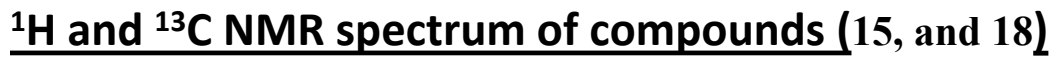

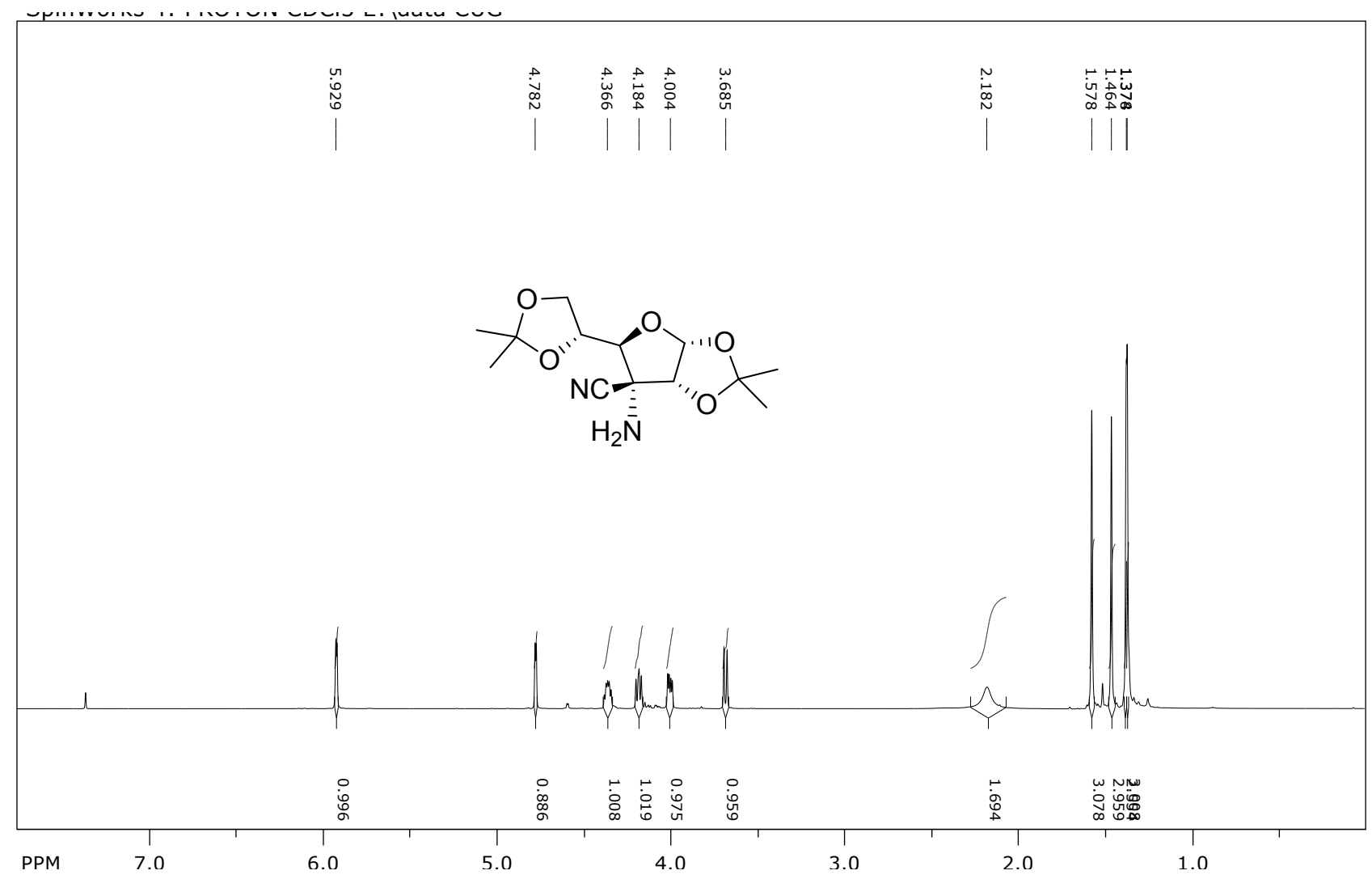

Figure S98. ${ }^{1} \mathrm{H}$ NMR of compound 18 in $\mathrm{CDCl}_{3}$ at $500 \mathrm{MHz}$ 


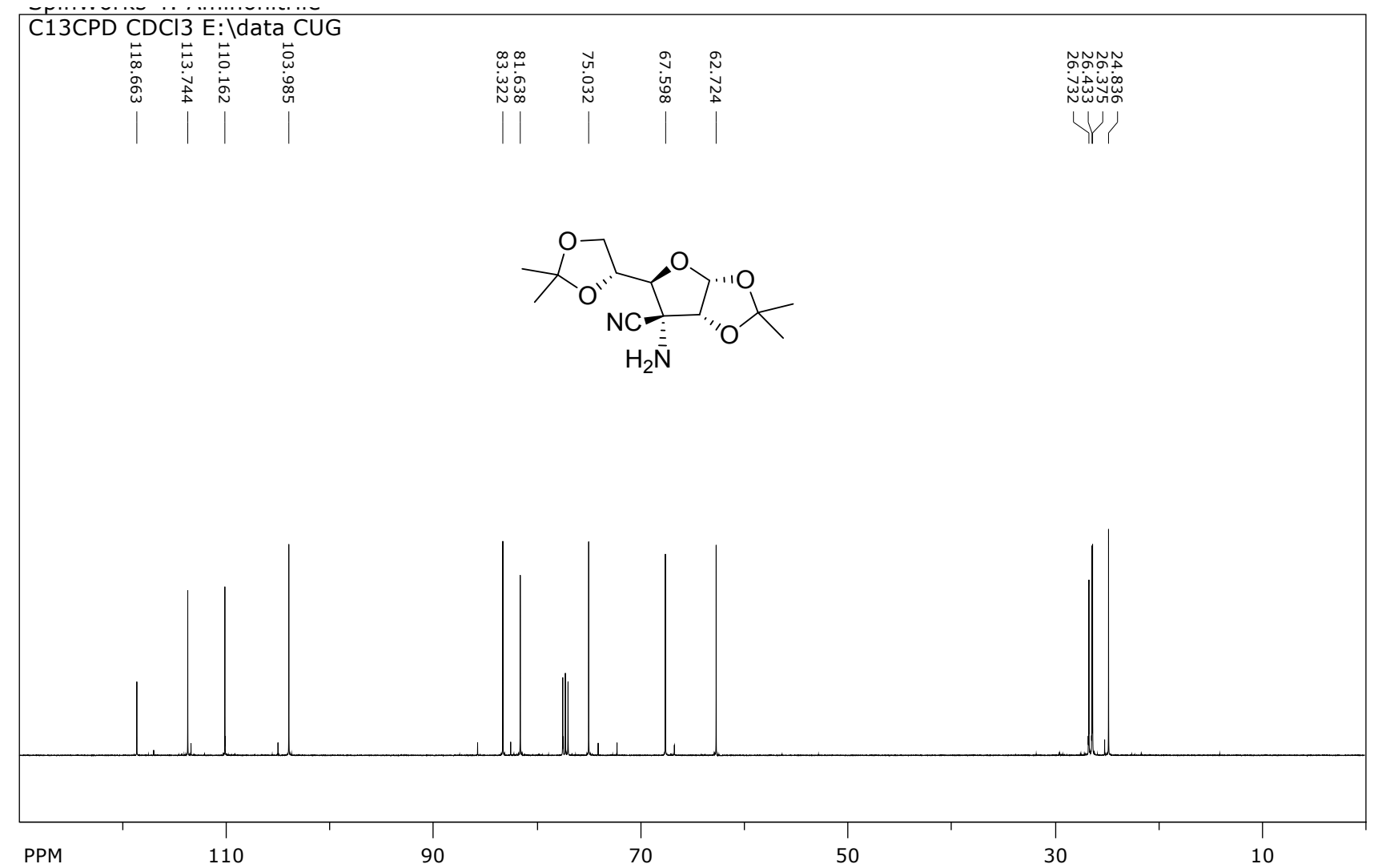

Figure S99. ${ }^{13} \mathrm{C} \mathrm{NMR}$ of compound 18 in $\mathrm{CDCl}_{3}$ at $500 \mathrm{MHz}$ 


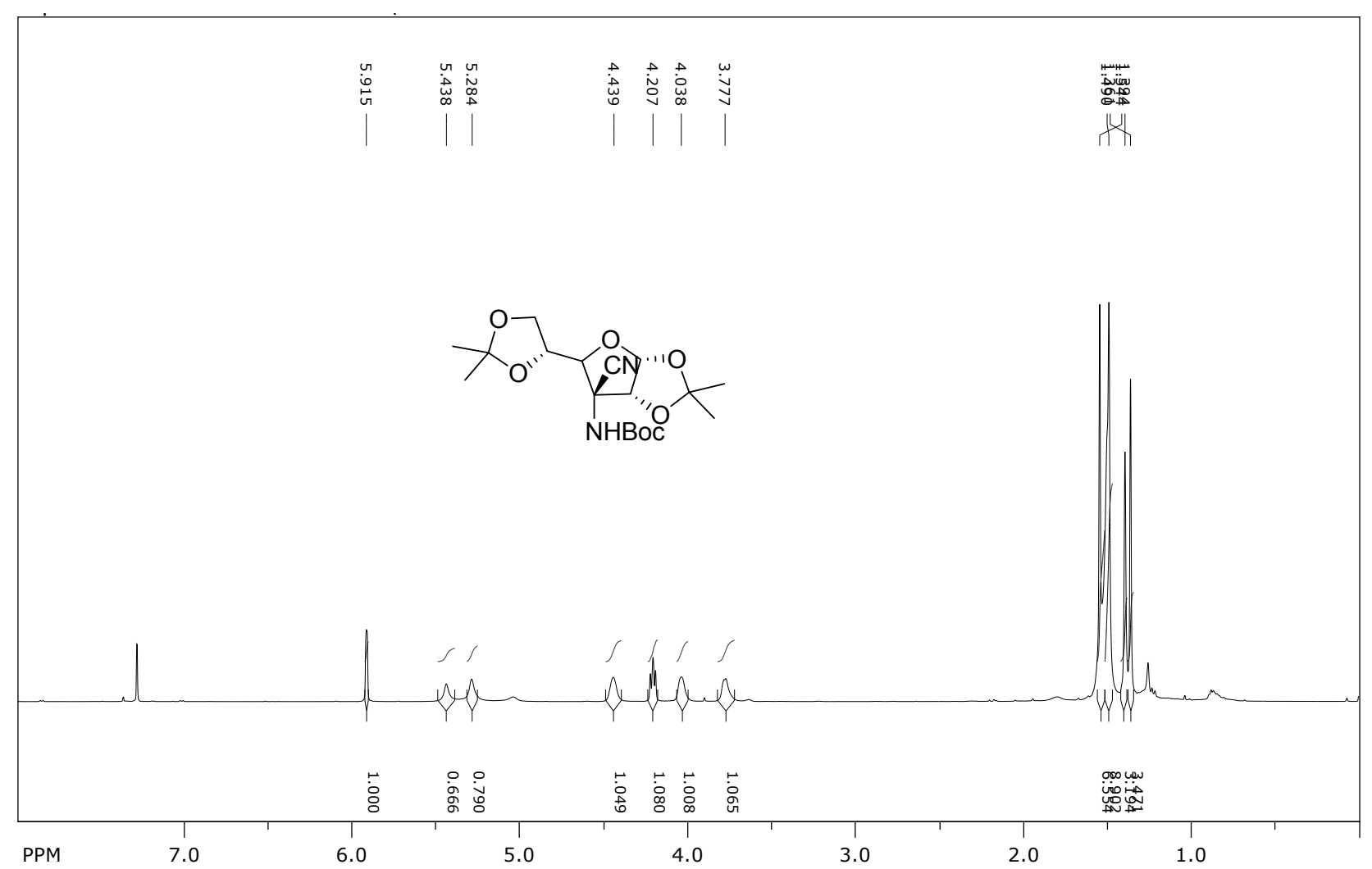

Figure S100. ${ }^{1} \mathrm{H}$ NMR of compound 15 in $\mathrm{CDCl}_{3}$ at $500 \mathrm{MHz}$ 


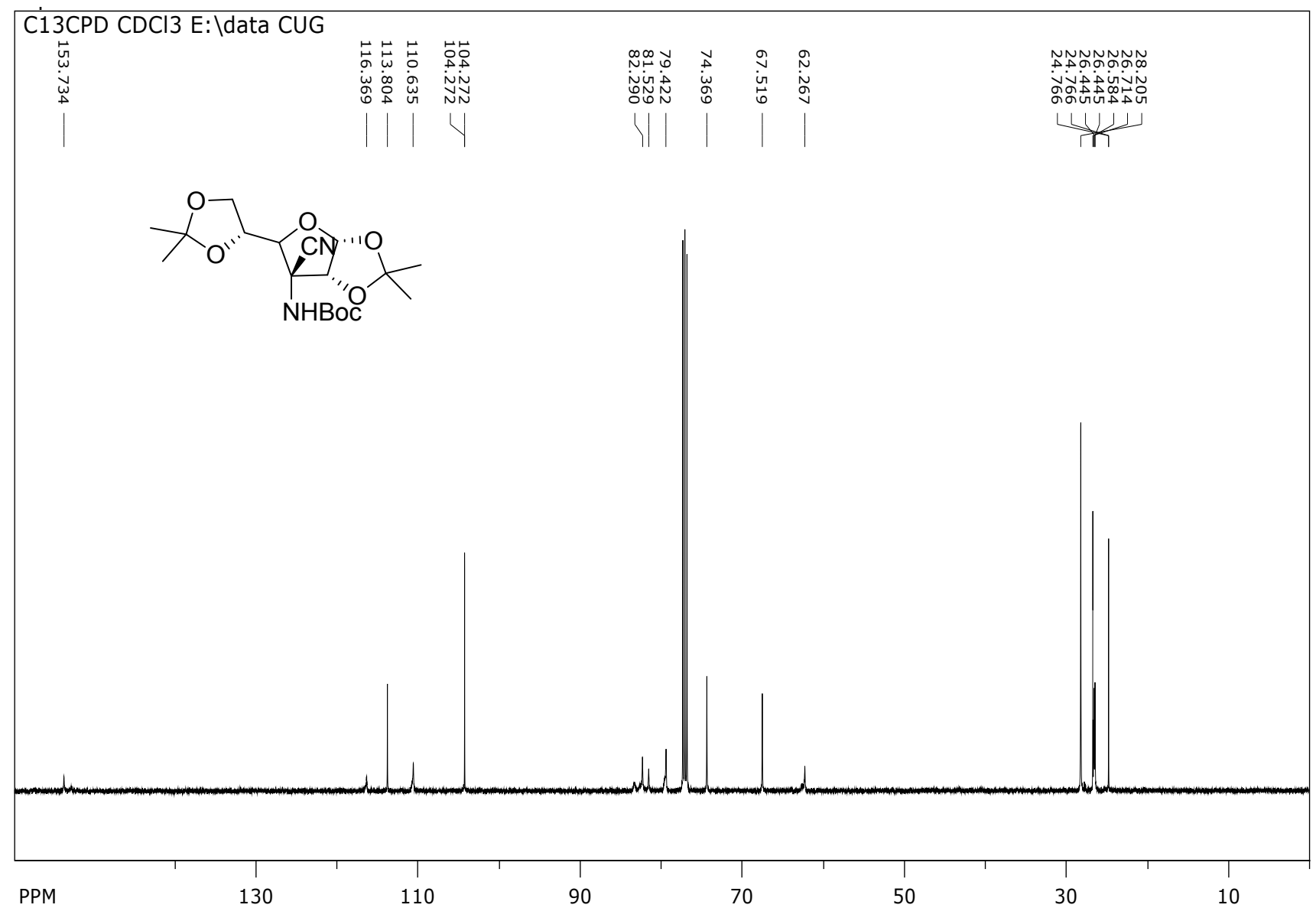

Figure S101. ${ }^{13} \mathrm{C}$ NMR of compound 15 in $\mathrm{CDCl}_{3}$ at $500 \mathrm{MHz}$ 